\title{
DEPTH OF SNOW.
}

Each entry is the Mean of the depth measured on the date given and on the preceding and succeeding day.

Up to July 1884 the depth was measured at the Thermometer Stand 12 yards E.S.E. from the nearest part of the house; all the other measurements were taken at Post A, 23 yards E. from the nearest frart of the house.

Up to July 1884 the measurements were taken at various times in the forenoon; all thereafter were made at $10^{\mathrm{h}}$.

\begin{tabular}{|c|c|c|c|c|c|c|c|c|c|c|c|c|c|}
\hline Month. & Day. & 1884. & 1855. & 1886. & 1887. & Nean. & Mouth. & Day. & 1884 & 1885. & 1886. & 1887. & Mean \\
\hline January & 1 & 70 & 46 & 44 & 43 & 51 & July & 1 & 3 & 55 & 30 & - & 22 \\
\hline " & 15 & 80 & 57 & 54 & 46 & 59 & ״ & 15 & - & 7 & - & - & 2 \\
\hline February & 1 & 107 & 66 & 85 & 35 & 73 & August & 1 & - & - & - & - & - \\
\hline$"$ & 15 & 105 & 122 & $\varepsilon 6$ & 39 & 88 & " & 15 & - & - & - & - & -. \\
\hline Maruh & 1 & 114 & 119 & 8.5 & 44 & 90 & September & 1 & - & - & - & - & \\
\hline$"$ & 15 & 114 & 122 & 82 & 44 & 90 & " & 15 & - & - & & - & - \\
\hline April . & 1 & 113 & 136 & 85 & 50 & 96 & October & 1 & - & - & - & - & - \\
\hline$"$ & 15 & 105 & 135 & 122 & 49 & 103 & $"$ & 15 & - & 31 & - & - & 8 \\
\hline May . & 1 & 117 & 128 & 104 & 67 & 104 & November & 1 & - & 31 & - & - & 8 \\
\hline " & 15 & 120 & 131 & 92 & 51 & 99 & $"$ & 15 & - & 23 & - & - & 6 \\
\hline June & 1 & 80 & 124 & 94 & 15 & 78 & December & 1 & 5 & 32 & - & 18 & 14 \\
\hline$"$ & 15 & 55 & 87 & 63 & - & 51 & $"$ & 15 & 33 & 44 & 13 & 46 & 34 \\
\hline
\end{tabular}

\section{OBSERVATORY LOG-BOOK.}

\section{3.}

Nov. 9.-Barometer No. 1252 was brought up yesterday, and hung in oak box beside the door of Mr Omond's room to-night.

Nov. 10.-To-day the first heavy fall of snow was encountered, the road being rendered impassable for ascent, and difficult for descent.

Nov. 12.-Glory seen on fog in north valley at $16^{\text {h }}$ $10^{\mathrm{m}}$ : radius of ring about $2^{\circ}$ by stephanome-red outside. There was also a small inner ring, a mere lump, also with red outside.

Nov. 13. - Just after sunset blue shadow of earth seen rising in eastern sky.

Nov. 17.-The floor of the Observatory was to-day ascertained to be 3 feet 3 inches below the Ordnance mark on the summit of the hill. The index point in the cistern of barometer in oak box is therefore 44051 feet above sealevel. This result is, however, only approximate, as the mode of measurement, with a sextant and artificial horizon used at a low altitude, did not admit of very great accuracy. Barometer No. 1385 having had a bubble of air shaken out of its stem, was to-day hung inside large Observatory window.

Nov. 20.-Flash of lightning, with thunder not three seconds after, at $10^{\mathrm{h}} 25^{\mathrm{m}}$. At $12^{\mathrm{h}} 30^{\mathrm{m}}$ telegraph instrument was examined, and lightning paper was seen to be scorched slightly. Another flash seen at $18^{\mathrm{h}} 45^{\mathrm{m}}$. Telegraph bell rang at same time, but insulation was not in any way injured. A ladder was to-day lashed vertically to the iron cage for thermometer box. It stands about 6 feet clear above the cage, and is well stayed up.

Nov. 23.-House fly seen crawling inside window of living room.

Nov. 24. - This morning snow at door was about eleven feet deep-for the first time a "tunnel " had to be bored up to daylight. Small box mounted on ladder at $16^{\mathrm{h}}$.

Nov. 25. - After observation at $20^{\mathrm{h}}$ the box inside iron cage was cleared out, all the instruments being taken in to the house. 
Nov. 28. - A weasel to-day came and looked in at window about $14^{\mathrm{h}} 30^{\mathrm{m}}$. Max. ther. No. 48026 (Negretti and Zambra) was broken in setting at $17^{\mathrm{h}}$.

Dec. 1.-Glory seen at $9^{\mathrm{h}} 15^{\mathrm{m}}$ (see fig. 1). Red outside in both rings. Smaller one almost filled up by shadow of head. Radius of red outer ring $=2^{\circ}$. At $11^{\mathrm{h}} 10^{\mathrm{m}}$ and $12^{\mathrm{h}} 0^{\mathrm{m}}$ white fog-bow - apparently same size as ordinary rainbow. When very bright it was coloured red outside. Too large to measure by stephanome. Got water from Wragge's well by digging away snow.

Dec. 3 .-At $1^{\text {h }}$ outside observations had to be given up till morning, as the snow was drifting in faster than one man could clear it out.

Dec. 6.-Fine all day, with fog and mist in valleys. Sunset red and green. Light from sunset sky gives strong atmospheric bands in spectrum, and at same time light from upper side of layer of fog gives only green part of spectrum. Blue is wanting both in it and in the sunset light. Corona round moon all evening. Red outside; radius $2^{\circ} 8^{\prime}$. Occasionally an outer circle of bluish colour extending from red ring outwards to a radius of about $4^{\circ}$ was visible. These measurements were taken at $20^{\mathbf{h}} 15^{\mathrm{m}}$

Dec. 7.-Shifted thermometer boxes, putting out fresh small one with dry and wet No. 7. Min. No. 138545, Max. No. 138590. Bulbs of dry and wet about 60 inches above snow. At $13^{\text {h }}$ snow crystals of feathery form were falling.

Dec. 9.-At $7^{\mathrm{h}}$ lightning rod was examined, and the crystals of drifted snow were found to form a thin slab, no thicker than the diameter of rod, pointing towards S.W., showing the wind had been steady. The hourly records for the night giving the wind as observed at iron cage, although mostly giving S.W. as direction, have some entries of W. and S.S.W.

Dec. 11.-Telegraph bell rung by earth current at $20^{\mathrm{h}}$ $2^{\mathrm{m}}$ and at $20^{\mathrm{h}} 8^{\mathrm{m}}$, insulation not injured. At $18^{\mathrm{h}}$ the doors were so blocked with drift that no outside observation was taken. One was made with considerable difficulty at $19^{\mathrm{h}}$, and then the door closed for the night. The wind was S.W. at $19^{\mathrm{h}}$, and at $9^{\mathrm{h}}$ on the 12 th was $N$. This change probably took place early, as the fire smoked badly all night, which it does with $\mathrm{N}$. winds.

Dec. 12. - Bulbs of thermometers in box were buried in snow up to $17^{\mathrm{h}}$. Wind very high all day. Snow drifted into box. The bulbs of dry and wet were not cleared of snow till after $17^{\mathrm{h}}$ observation.

Dec. 13. - At $2^{\text {h }}$ rain was falling, and air felt much milder than indicated by thermometers. At $16^{\mathrm{h}}$ rain falling on box froze as it touched it, forming a skin of ice. At $17^{\mathrm{b}}$ rain turned into hail, which continued till $21^{\mathrm{h}}$, when snow began.

Dec. 14.-At $16^{\mathrm{h}}$ hinges were taken off outer door, and screwed on inside. In consequence, no observation was taken at $17^{\mathrm{h}}$. The late thaw covered the pavement at outer door with about an inch of slush; this froze hard, and needed to be hacked away with a hammer.

Dec. 15.-To-day an arched porch of snow was begun over east door.

Dec. 16.-Heavy snow at night and in early morning. Depth at cage over 100 inches. During day strong N. and N.E. winds which swept snow away from roof and $\mathrm{E}$. and W. sides of house. The depth at cage was reduced from 108 to 60 inches in less than 20 hours; the parts where it was beaten hard by our feet-as on track from door to cage-standing 5 to 10 inches above general level. At $\delta^{\text {h }}$ sky to $N$. (only part clear) was green. At night sky covered with detached masses of low misty cloud driving over hill top.

Dec. 17.- In early morning and also at night corona seen; at $2^{\text {h }}$ double ring, red outside in both.

At $22^{\mathrm{h}}$ triple ring, red outside in all three. Radius of middle red, $1^{\circ} 45^{\prime}$. Also lunar rainbow, white, radius $26^{\circ}$ (colours, if any, very faint). At midnight faint corona. Lunar fog-bow at $23^{\text {h }}$ too large to measure. Drizzling rain came on at $18^{\mathrm{h}}$, with a temperature of $25^{\circ}$.

Dec. 18.-Badly defined corona at $6^{\mathrm{h}}$. Red outside. Radius $=2^{\circ}$

Dec. 19. - At $13^{\mathrm{h}}$ thermometers taken into house, and fitted to other small box. Put out again at $14^{\mathrm{h}} 2^{\mathrm{m}}$. Hence no temperature readings at $14^{\mathrm{h}}$, and no max. reading at $15^{\mathrm{h}}$. A tin box painted white was placed under thermometer box, and at $17^{\mathrm{h}} 20^{\mathrm{m}}$ the thermograph was put into it and the box shut tight. By $21^{\mathbf{h}}$ the west side of tin box was covered with ice; but by $22^{\mathrm{h}}$ ice almost gone. (It had been rain since $17^{\mathrm{h}}$, and a thaw came on gradually.)

Dec. 21 .- This morning at $6^{\mathrm{h}} \mathrm{Mr}$ Omond's watch, the only timepiece at present in the Observatory, ran down, not having been wound. It was not observed for about half an hour, and then put on by gness. In consequence the $7^{\mathrm{h}}$ and $8^{\mathrm{h}}$ observations were taken at $7^{\mathrm{h}} 5^{\mathrm{m}}$ and $8^{\mathrm{h}} 5^{\mathrm{m}}$ respectively - and in consequence of inaccurate time sent up from Fort William the $9^{\mathrm{h}}$ and $10^{\mathrm{h}}$ observations were taken at $8^{\mathrm{h}} 55^{\mathrm{m}}$ and $9^{\mathrm{h}} 55^{\mathrm{m}}$ respectively.

Dec. 22.-At $21^{\mathrm{h}}$ snow lying in large wreaths; a tail to S.S.E. of cairn.

Dec. 23. $-12^{\mathrm{h}} 30^{\mathrm{m}}$ cir.-str. seen to $\mathrm{S}$. Reddish hue round sun; diameter about $15^{\circ}$. At $15^{\mathrm{h}} 10^{\mathrm{m}} \mathrm{sm}$ sank into cloud bank. As it went down semicircle of colours formed over edge of cloud bank, red outside, like badly defined corona. Sky above covered with brok:n stratus, and not coloured at all. Snow has accumulated in deep drifts near house.

Dec. 24.-Rain began at midnight on 23 rd, and continued all 24th. Snow crystals on box and ladder turned to ice, and at $7^{\mathrm{h}}$ on 24 th were melting away.

Dec. 25.-. Very fine day. Air dry and warm. At $8^{\text {h }}$ yellow sky to E. At $8^{\mathrm{h}} 15^{\mathrm{m}}$ whole east sky from N.E. to S.E. green near horizon, blue higher up, and violet towards zenith. Filmy cirrus to E. Very beautiful. At noon sky cleared, and sun shone all afternoon. Fog or cloud covered lower hills, and filled valleys all afternoon. It rose sometimes as high as the Plateau of Storms, but was mostly below 3000 feet on Ben Nevis. Not another hill showed through it, however. Fleeting badly defined glories seen all afternoon on fog in north valley. Red always outside. $16^{\text {h }}$ very fine red sunset. Earth shadow seen to E. $17^{\mathrm{h}}$ red streak to W. Pale green above. Dark blue sky. $21^{\mathrm{h}} 7^{\mathrm{m}}$ meteor seen. Brightness $=$ Jupiter. No sound or sparks; moved from point S.S.W., $40^{\circ}$ elevation to point S.W. by W. $25^{\circ}$ elevation, where it disappeared in cloud bank. Bluish. Everything outside dried up. Ropes all slack.

Dec. 26.- Very fine views of sky and clouds. Sky at sunrise very red. Sky under sun continued red or copper coloured all day. At lorizon, at right angles to direction of sun, sky blue; opposite sun, near horizon, green. These 
colours were more or less marked all day. Fog filled valleys, were free. It was the one to windward. The instrument and lay over lower hills, though not in such a continuous was not examined again till $5^{\mathrm{h}}$ on $30 \mathrm{th}$, when it was found sheet as yesterday. The sky continued clear all night; to be thickly covered with snow crystals, and quite unreadstars very bright, but temperature did not fall. At able. It was therefore taken in. Dry bulb temperature $20^{\mathrm{h}}$ it rose from $28^{\circ}$ to $32^{\circ}$, and continued well above at $5^{\mathrm{h}}, 22^{\mathrm{D}} \cdot 1$.

freezing point all night. At $15^{\mathrm{h}}$ sun sank into cloud bank.

Dec. 27.-At $7^{\text {h }}$ red streak round eastern horizon. This gradually brightened, and turned to yellow just before sunrise; at the same time the sky near W. and S.W., horizon being blue-green in colour. The hills near were well seen, snow greatly melted off them. Before noon fog and mist came on, which continued all afternoon. No fresh snow having fallen for several days, the surface is hard and firm - in many places compacted into ice by the rain which fell at beginning of thaw.

Dec. 28.-Barograph was found to have stopped at $11^{\text {b }}$ on Dec. 27. Put on again at $2^{\text {h }}$ Dec. 28. Cause of stoppage unknown.

Dec. 29. - At $16^{\text {h }} 40^{\text {m }}$ three-bulb thermometer put ont, hanging exposed on nail at east side of posts on which box was.

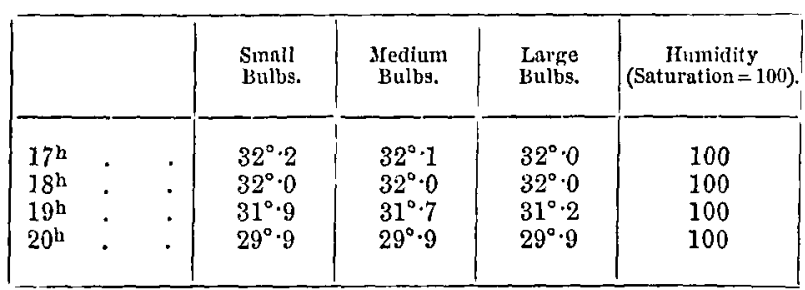

Dec. 30.-Fine day, with wonderful colour effects. At sunrise the renith Red sky was very blue. The sun rose from Yellow cloud bank. About $3^{\circ}$ above which was Pale green a layer of dark stratus. Colours and Cloud bank) clouds as indicated in margin. To the N.E. sky at horizon was a dirty-green colour. Sun shone brightly all day, with curious reddish or copper colour under it, increasing in intensity downwards to horizon. Max. rending of black bulb in vacuo, 47 inches above snow, $73^{\circ} \cdot 8$ at $13^{\mathrm{h}}$. Shade temperature at same time $19^{\circ} \cdot 5^{\prime}$. Meteor seen at $20^{\mathrm{h}}$. Started from Orion, and went downward at an angle of $70^{\circ}$ to horizon to westward. Clear starlight night; very fine.

Dec. 31. - At $7^{\mathrm{h}}$ dark red streak round eastern horizon for about $60^{\circ}$. At $\delta^{\mathrm{h}} 15^{\circ}$ Pale violet colours as shown in margin. At $9^{\mathbf{h}}{4^{\circ}}^{\circ}$ Green colours disappearing. Sun shone all day; Horizon dull reddish colour round horizon under it-greenish colours at opposite azimuth. Sunset red, passing into blue above S.S.E., sky copper colour. N.E. dark bluegreen, becoming at $16^{\mathrm{h}} 30^{\mathrm{m}}$ a yellowish-green. Above sun after sunset, sky red, passing into blue, and that into green still higher up. Above the green a curious mauve tint. These colours gradually died out from At $19^{\mathrm{h}}$ the small bulb was couted with ice, the others $\mid \begin{aligned} & \text { above. The moon was green, and } \\ & \text { as observed. Clear starlight night. }\end{aligned}$

\section{4}

Jan. 3.-At $7^{\text {h }}$ blood-red colour on eastern horizon, red and green to $\mathrm{E}$. at $\mathrm{S}^{\mathbf{h}}$. Sunrise red; very fine. Day dull, but with green and copper coloured sky to north. Southerly sky clouded and dark. Wind was S.E., and it was noticed, when fog blew up over the top from Glen Nevis, that the wind lulled as the fog came up. Dark clouds were hanging about all day, and in evening they formed a canopy over hill, leaving horizon clear. At $17^{\mathrm{h}}$ $35^{\mathrm{m}}$ lunar halo. Radius $17^{\circ}(?)$. Colour white, very faint.

Jan. 5.-Very stormy. At $7^{\mathrm{h}} 28^{\mathrm{m}}$ wind southerly; blew lamp of observer out several times. This is the first time this has happened.

Jan. 6.-Everything covered with ice, either solid or crystalline. At $4^{\mathrm{b}}$ thermometer box was frozen so fast that it needed chisel to open it. Copper wire stays on stove pipe grew to 4 inches diameter of solid ice. At $10^{\mathrm{h}}$ some snow-flakes about 1 inch diameter were observed.

$J a n$. 7.-At $9^{\text {h }}$ there was more than an inch of solid ice on thermometer box and on thermograph (tin) box. At $20^{\mathrm{h}}$ mist and cloud driving over hill, fleeting coronas (red outside) forming as they passed.

Jan. j0.-9th and 10th very stormy. At $14^{\mathrm{h}} 35^{\mathrm{m}}$ indicator of telegraph instrument moved by earth current. Corona seen about $20^{\mathrm{h}} 20^{\mathrm{m}}$.

Jan. 11.- Heavy drift all forenoon. Thermometer box had to be cleared several times.
Jan. 12.-Thermometer box shifted. Taken in after noon observation. Max. and min. put out at $12^{\mathrm{h}} 31^{\mathrm{w}}$. But dry and wet were so hard frozen in that they conld not be got clear of the old box till $13^{\mathrm{h}}$, when they were put out. At $19^{\mathrm{h}}$ the bulls of thermometers were 38 inches above snow. At $21^{\mathrm{h}}$ the box was covered with ice.

Jan. 14.-This last two days everything has been covered with ice; the thermometer box needed to be cleared several times, the ice being hacked off with a chisel. The box taken in at noon on Jan. 12 th took about 40 hours to thaw, although it was standing in a large pail about one yard from side of stove.

Jan. 15. - Between midnight (Jan. 14) and $1^{\text {h }}$ lunar corona seen. Distinct orange ring, $2^{\circ} 30^{\prime}$ radius ; inside of which is the true corona, with blue next moon. Outside orange ring a bluish-green space edged with red or orange rim. This space did not look like a second corona; the colour was too uniform. Radius of outer red ring $5^{\circ}$. This green in the outer ring strongly resembled the green tints seen in the recent sunsets. Moon gare usual continuous spectrum, but as the spectroscope was moved aside, just after leaving the outer edge of all, a pale lilac colour appeared at the green part of spectrum. At $14^{\mathrm{h}}$ the moon was surrounded by a very faint corona entirely blue.

Jan. 16.-At $10^{\text {h }}$ put out sunshine recorder for first 
time. Sun was at times obscured by thin haze; a thick bank of cloud or fog lay over the other hills. Reddishbrown copper colour in sky under sun all day; and more faintly, pale green at northern horizon. 'Towards sunset a rosy haze to N.E. The sunset was fine, though the colours had not the peculiar tints of the sunset lights at the beginning of the month. As the sun sank into the low-lying cloud bank to westward, the south-western horizon was coloured copper and reddish, while the northeast was bluish-green, with pink clouds above it. After Reddish sun had set, colours were as in margin. Green The reddish colour was apparently on a Orange very fine filmy cloud; above it sky was Cloud purple, passing into blue at zenith. The reddish glow died down from the top, and the lower colours turned into pale yellow, smoky to S., and pale green to N.W. Finally, a dark red streak was left in S.W., passing into yellow, green, and blue above. Venus appeared shining with bluish light. By $19^{\mathrm{h}}$ the colours were all gone. Black bulb thermometer was put out at $13^{\mathrm{h}} 35^{\mathrm{m}}$, highest reading $73^{\circ} \cdot 3$, corresponding shade temperature $32^{\circ} \cdot 0$. Moon rose soon after $22^{\mathrm{h}}$, and till midnight was surrounded by a greenish-blue colonr for about $15^{\circ}$ on each side. Below this a reddish hazy colour near horizon. Colour near moon gave faint green, and nothing else in spectroscope.

Jan. 17.- Mist from $4^{\text {h }}$ onwards all day.

Jan. 19.-Very fine in forenoon. Southern horizon yellow, northern faintly green; no copper colour seen. Black bulb put out, highest reading $76^{\circ} \cdot 2$, shade temperature $26^{\circ} \cdot 5$. At $14^{\mathrm{h}}$ clouds began to appear, at $14^{\mathrm{h}} 40^{\mathrm{m}}$ sky was entirely overcast, and at $16^{\mathrm{h}}$ top was covered with mist. Wind very high at night from S.W.

Jan. 20.-Very stormy all day. At $21^{\mathrm{h}}$ Mr Omond and Mr Rankin went to take observation roped together.

Jan. 21.-Very stormy in early morning and evening. At $19^{\mathrm{b}}, 20^{\mathrm{h}}$, and midnight, $\mathrm{Mr}$ Omond and Mr Rankin took observation roped together. No temperature observations taken at $21^{\mathrm{h}}, 22^{\mathrm{h}}$, and $23^{\mathrm{h}}$. At $19^{\mathrm{h}}$ a bright light was seen along the edge of the cliff, forming a white glare about 10 feet broad, and lighting up the whole top of the hill. May have been due to snow blowing over and getting illuminated from below.

$J_{a n}$. 22.--No temperature observation taken at $1^{\text {h }}$, but after that wind moderated, and ordinary observations were resumed. About 9 inches of fresh snow lying over old hard surface.

Jan. 23.-Very stormy, with heavy snow-drift. At $14^{\mathrm{h}}$ box so choked with drift that wet and dry were unreadable ; temperature taken from spirit of min. At $15^{\mathrm{h}}$ the porch was so blocked with drift that exit was impossible, but at $16^{\mathrm{h}}$ observations were resumed.

Jan. 24. - At $1^{\text {h }}$ the door of the thermometer box was found torn off its hinges lying on the snow. Boxes were shifted at $13^{\text {h }}$, the first hour at which it was practicable; but dry and wet were not put out till $19^{\mathrm{h}}$. In spite of constant drift, the fresh snow was very much blown away.

Jan. 26. - In forenoon wind backed from S. to S.E., and blew hard. As the drift made it impossible to read thermometer at $13^{\mathrm{h}}, \mathrm{Mr}$ Omond and Mr Rankin went out tied together, but found it impossible to go further than the end of the snow porch with safety; at $16^{\mathrm{h}}$ they got as far as the box, but could not see instruments as the drift blew up into their faces. No temperature observations were

TRANS. ROY. SOC. EDIN. VOL. XXXIV. taken till $22^{\mathrm{h}}$, when wind moderated, and observations were resumed. There was thus a gap in the temperature observations from noon to $21^{\mathrm{h}}$ inclusive. Quarter and halfhourly barometer observations were taken in afternoon. Lowest recorded reading (corrected to $32^{\circ}$ ) $23 \cdot 173$ inches.

Jan. 28.-At $9^{\text {h }}$ the thermograph was taken in completely covered with fine snow, which had penetrated by the hinges of the tin box. It was nevertheless working as usual. From $9^{\text {h }}$ till noon the top was clear, and the sun shone very hotly at times. At noon fog was observed coming on from N.W.

Jan. 30.-During the day the wind veered to N.W., and at $20^{\mathrm{b}}$ the fire smoked so badly that the observers had to leave the house and stay outside for nearly an hour, till it moderated. One flash of lightning seen at $20^{\mathrm{h}} 30^{\mathrm{m}}$. At $22^{\mathrm{h}}$ the needle of A B C telegraph indicator was found at $\mathrm{D}$.

Jan. 31.-Top cleared at noon. Copper colour under sun, and green to N.; but not strong.

Feb. 1.-In evening the wind was very squally; observers needed to be roped at times.

Feb. 2.-At $6^{\text {ht }}$ fog cleared off, leaving cumulus (5), and showing a filmy arch of light, extending from northeastern to south-eastern horizon. At $7^{\mathrm{h}}$ the eastern horizon was pale green and yellow below, and pink above. At $\delta^{\text {h }}$ the pink, yellow, and green had risen higher, and a red band was seen at horizon. By $9^{\text {h }}$ the sun was shining, with a brownish haze under it; sky bright and clear. At $10^{\mathrm{h}}$ the sky was hazy, and a very fine misty or dusty matter was passing along above Glen Nevis; it was only visible when the sun shone brightly on it. At $10^{\mathrm{h}} 15^{\mathrm{m}}$ everything was clear, and the colours in the sky very strongly marked; but at $10^{\mathrm{h}} 30^{\mathrm{m}}$ the other hills were buried in fog. The fog continued gathering on and driving over the lower hills, and between $16^{\mathrm{h}}$ and $17^{\mathrm{h}}$ the top of Ben Nevis was covered again. At $11^{\mathrm{h}}$ the thermometer box was taken off ladder and placed on a stand 17 inches above snow, while extra joint was being fixed to ladder. After $16^{\mathrm{h}}$ observation, the max. and min. were put into fresh box on ladder 54 inches above snow, while the old box was taken in. The dry and wet were frozen hard into it, and while taking them out at $23^{\mathrm{b}}$ the dry bulb was broken. At midnight wet bulb No. 7 was put out as a dry bulb.

Feb. 3. - At $4^{\mathrm{h}}$ crystals of ice and sleet fell. By $15^{\mathrm{h}}$ the thermometer box was thickly covered with ice; this was cleared off at $19^{\mathrm{h}}$, and no fresh ice formed till $7^{\mathrm{h}}$ on 4 th.

Fel. 7.-About noon two birds, thought to be hawks, were seen flying backwards and forwards over the ridge to N.E. of Ben.

Feb. 9.-At $15^{\text {h }}$ hill tops round were seen with very little snow on them. A weasel (white) seen at window next Mr Omond's room.

Feb. 13.-Not much snow on other hills; apparently none below 3000 feet.

$F e b$. 14.-At $16^{\text {h }}$ fog disappeared off Ben Nevis, leaving white mist rolling about below round the other hills, but sky clear. Faint copper colour to S.W. where horizon was hazy, and very faint yellow-green to $N$. At $17^{\mathrm{h}}$ sun was setting into thick bank to S.W.; fog had partly cleared off other hills, and was driving over top of Ben at times. At $17^{\mathrm{h}} 40^{\mathrm{m}}$, just after sunset, there was a pale crimson streak above bank of cloud, then belt of stratus dark red, then yellow-green passing above into pale green, then a 
purple glare passing into the blue sky above. At $17^{\mathrm{h}} 50^{\mathrm{m}}$ only streaks of yellow and red above cloud bank, above this crimson, above that a peculiar yellow-red passing through a whity-green into the blue of the sky. At $18^{\text {h }}$ red streak to W.S.W., with belt of dark stratus above it, and pale green above that. Dirty yellow to N.W. and S.W. No colour to N.E. Other hills clear of fog, and stars coming out in clear sky. At $19^{\mathrm{h}}$ still a faint greenish glow low down to W. At $22^{\mathrm{h}}$ moon rose yellow in colour. At $23^{\text {h }}$ there was a reddish or copper colour under her.

Feb. 15.-Very stormy. Every thermometer observation, except the one at $9^{\text {h }}$, taken by two observers roped together.

Feb. 16.-Very stormy; every observation from $9^{\text {h }}$ to $19^{\mathrm{h}}$ inclusive taken by two observers roped together. At $20^{\mathrm{h}}$, as soon as $\mathrm{Mr}$ Omond went outside door of snow porch, he was lifted off his feet and blown back against Mr Rankin, who was knocked over. Therefore no thermometric observations were taken at $20^{\mathrm{h}}$ and $21^{\mathrm{h}}$.

$F e b .17$.- Very stormy. Every observation from $9^{\text {h }}$ to $21^{\text {h }}$ inclusive taken by two observers roped together.

Feb. 18.--Snow porch almost entirely blocked with drift, no observation taken outside at $10^{\mathrm{b}}$; every other one from $9^{\mathrm{h}}$ to $21^{\mathrm{h}}$ taken by two observers roped together. At $17^{\mathrm{h}}$ fog began to break into very dark scud flying close over hill. Top remained clear till $5^{\mathrm{h}}$ next morning.

Feb. 19.-Very stormy. Every observation from $9^{\text {h }}$ to $21^{\mathrm{b}}$ inclusive taken by two observers roped together. The snow crystals formed on ladder, \&c. for last few days have been of a greyish colour, with an oily taste.

Feb. 20.-Wind lulled in early morning, but rose again at night.

Feb. 21.-Very stormy in morning; lulled in middle of day. Top clear. At noon cir.-str. seen forming to $S$. and S.W. No special colours at horizon, but at $19^{\text {h }}$ a pale glimmer to $\mathrm{W}$.

Feb. 22.-Top clear. No colours in sky except faint copper colour under sun above white fog lyingr over southern hills.

Feb. 23.-Thermometer box shifted at $11^{\text {h }}$. At $19^{\text {b }}$ whitish-green glow to N.N.E. Dark red low down to westward.

Feb. 24.-From midnight (Feb. 23) to $4^{\mathrm{h}}$ aurora seen. Got gradually fainter up to $4^{\text {b. }}$. Only one streamer observed rising at intervals from the same part of arc. Arc very low down, not above $5^{\circ}$ to top. No colours or sounds. At $9^{\text {h }}$ top clear, and hills round free of fog. Copper colour under sun; other sky normal. At $13^{\text {h }}$ white fog formed on hills $\mathrm{E}$. and W. of Ben, and by $14^{\mathrm{b}}$ top in fog. Fog only lifted once during afternoon. Upper sky had some cirrus on it lying N.W. and S.E., moving probably from N.E.

Feb. 26. - Glories seen occasionally at cliff.

Feb. 27.-Minimum thermometer laid on cotton wool on snow all night. Reading at $9^{\mathrm{h}} 17^{\circ} \cdot 7$. Corresponding minimum in box $17^{\circ} \cdot 1$.

Feb. 29.- Stormy in early morning; door almost blocked with drift. Shifted thermometer box at $10^{\mathrm{h}}$.

Mar. 1.-Snow porch at outer door is now about 33 feet long, with a rise of about 12 feet in its floor.

Ifar. 4.-At $10^{\mathrm{h}} 50^{\mathrm{m}}$ solar halo observed. Red inside. Colours very faint. Approximate measurement of radius by stephanome $22^{\circ}$. At $20^{\mathrm{h}}$ lunar halo observed, white.
Very faint, approximate radius $23^{\circ} 45^{\prime}$. At $21^{\mathrm{h}}$ corona observed. Double. Usual colours from moon out to first red ring. Then bluish annular space tinged with red outside. Radius of first red $2^{\circ}$, second $4^{\circ}$.

Mar. 6.-Box shifted at $18^{\mathrm{h}}$. By $19^{\mathrm{h}}$ coating of ice on box to windward.

Mar. 8. -At $5^{\mathrm{h}} 10^{\mathrm{m}}$ a peculiar glow was observed all round horizon. To $N$. and $E$. it was partly hid by banks of stratus, but to S. and W. it took the form of an arch or belt of light, white in colour, and dipping down to southern horizon. The breadth of the belt to S. was about $10^{\circ}$. The height of top, at highest point to W., about $30^{\circ}$. The upper edge was distinctly marked, the lower one filmy and indistinct. The stars were seen through it, and the sky above the dip to $\mathrm{S}$. was very dark. It was calm at the time, cloudy and very quiet. At $6^{\text {h }}$ the clouds to S. were very ugly. The wind slowly increased from S., and by midnight was force 6 to 7 . Slight snow shower in forenoon.

Mar. 10.-Heavy squall at night. The $21^{\mathrm{h}}$ observation was taken by two observers, and none other was taken till after midnight.

Mar. 11.-Fine all day. At $5^{\text {h }}$ detached thin clouds passing under moon formed coronæ at times. At $6^{\mathbf{h}}$ eastern horizon coloured yellow, blue, and violet. Though the sky was pretty clear, the atmosphere was scarcely ever dry, and detached masses of cumulus were observed floating above most of the surrounding hills.

Mur. 15.-At $20^{\mathrm{b}}$ the sky, where not obscured by clouds, was of a milky white colour, through which the stars were seen. At $23^{\mathrm{b}}$, just before the moon rose, there was a cone of misty whitish-green light rising from eastern horizon.

Mar. 21.-At $17^{\text {h }}$ shifted thermometer box.

Mar. 26.-Fine all day. Sky blue, without any unusual colours in it, except a brown haze round the sun. For most of the day there was white fog or stratus over the southern hills, while all the northern and western horizon was hid by a low-lying dark purple haze. Sky became overcast, and fog came on in evening.

April 1.-At $14^{\text {h }}$ thermometer box was shifted. April 7.-At $3^{\text {h }}$ lunar halo observed, not well defined, white. Radius by stephanome $22^{\circ}$ to $23^{\circ}$. At $11^{\text {hi }}$ ther. mometer box shifted.

April 8. $-\Lambda \mathrm{t} 3^{\mathrm{h}}$ a double corona seen; and at $3^{\mathrm{h}} 5^{\mathrm{m}}$ a meteorite. All day cumulus fog over surrounding hills. At sunset at $20^{\text {h }}$ the sky to N.W. was coloured as in margin, the yellow coming down to the (Stratus) horizon to westward. At $23^{\mathrm{h}}$ a blue Yellow and lunar corona observed, radius about $4^{\circ} 25^{\prime}$ Green by stephanome.

A pril 9.-Lunar blue corona seen up to $3^{\text {h }}$. Very fine morning; but later cumulus fog formed over southern hills and in valleys, passing over Ben Nevis at times. By $15^{\mathrm{h}}$ fog was completely covering hill top.

April 10. At $2^{\mathrm{h}}$ Iunar corona observed. Inner space blue, then green ring, and red ring outside Blue all. Radius of red ring $4^{\circ} 15^{\prime}$. At $5^{\text {h }}$ Purple sunrise colours of sky seen as in margin. Green Horizon hazy all day; at night haze rose Yellow higher, and moon was seen through it of a Red blood-red colour.

April 11.-In morning heavy cumulus fog over surrounding hills, occasionally passing along sides and over 
top of Ben Nevis. Top in fog from $11^{\mathrm{h}}$ to $15^{\mathrm{h}}$. At $23^{\mathrm{h}}$ heavy cumulus fog all round, and red glare under moon. At $17^{\mathrm{h}} 20^{\mathrm{m}}$ an earth current moved needle of A B C telegraph indicator six letters on dial.

April 13.-At $4^{\mathrm{h}}$ lunar corona observed, very misty looking, with red ring inside an outer green one. Cumulus cloud, and fog round horizon all day.

April 14.-Heavy dark clouds, and fog round horizon all day.

A pril 15.-Dark cumulus round horizon all day.

April 17.-Stratus and cumulus hanging about horizon all day. Sunset very fine, showing all the spectroscopic gradations of colour. At $22^{\mathrm{h}}$ a mastrificent aurora was observed. It formed a double arch of light, with dark space under it. At $22^{\mathrm{h}} 5^{\mathrm{m}}$ streamers were shooting upwards from all parts of both arches, and at $22^{\mathrm{h}} 12^{\mathrm{m}}$ the two disolved into one broad, badly defined arch. The centre of the upper arch was about $20^{\circ}$ above horizon, and of the lower arch $10^{\circ}$. The upper extended from W.N.W. to E.N.E., and the lower from N.W. to N.E. After $20^{\mathrm{h}} 15^{\mathrm{m}}$ the aurora consisted mainly of horizontal waves of light, rolling upwards to nearly the zenith, and apparently converging there. Mingled with these waves were long rays, shooting upwards towards the zenith, and reaching to within about $15^{\circ}$ of it. By midnight it had disappeared; but the upper edges of the clouds on northern horizon were still luminous. No definite reflection of the aurora in any of the lochs was observed, and no spectroscopic observations were made on it. A meteor was seen near zenith at $22^{\mathrm{l}} 20^{\mathrm{m}}$. Quiet, fine, but rather dull weather followed for the next few days.

April 21.-At $8^{\text {h }}$ with light fog overcast sky, and temperature of $25^{\circ} \cdot 8$, small soft crystals of snow fell; dead calm at the time.

A pril 23.-Grey crystals of snow forming; some an inch and half loug.

April 24. - From $22^{\mathrm{h}}$ to milnight a luminous appearance in sky and clouds, especially to N.E.

A pril 25. - At $1^{\mathrm{h}}$ a faint aurora seen; no arch visible, but streamers, very bright at times, were observed rising to a height of about $30^{\circ}$. At $2^{\text {h }}$ faint glimpses of the aurora were seen through fog. At $3^{\mathrm{t}}$ neither arch nor streamers were seen, but spasmodic flashes of light rose, apparently from quite close at hand in the fog towards the zenith. At $3^{\mathrm{h}} 5^{\mathrm{m}}$ fog cleared off, and a cone of light with its base along horizon from N.N.E. to E.S.E., and its vertex $5^{\circ}$ east of Cassiopeia was seen. At $4^{\mathrm{b}}$ the cone was larger, reaching to within $20^{\circ}$ of zenith. The needle of $\mathrm{A} \mathrm{B} \mathrm{C}$ telegraph instrument was moved on three letters by an earth current at $3^{\mathrm{b}} 5^{\mathrm{m}}$. At $3^{\mathrm{h}} 5^{\mathrm{m}}$ bright meteor seen. Started at $30^{\circ}$ elevation, bearing E. and S., and fell vertically downwards.

April 28.-At $3^{\text {h }}$ triangular patch of sky rising from N.E. horizon as far as Cassiopeia, of a milky aspect. Very few clouds at the time. Sun did not rise till after $4^{\text {h }}$.

April 30.-At $1^{\text {h }}$ doorway was almost choked with drifted snow. At $10^{\text {h }} 30^{\text {m }}$ a heavy shower of very large

Red

Green

Reddish

Yellow

D

May 4.-The hills round Ben Nevis were seen to be covered with fresh snow for a great part of their height.
At $14^{\mathrm{h}} 45^{\mathrm{m}}$ leavy hailstorm with thunder. The needle of $A B C$ telegraph indicator moved on three letters.

May 6.-Box shifted after noon observation. Badly defined lunar corona seen at midnight. Radius of red ring $3^{\circ} 45^{\prime}$; of blue $2^{\circ}$.

May 7.-At $8^{\text {h }}$ a solar halo observed, red inside, bluish colour outside. Fog was passing at the time, and when it came on, the halo disappeared; but a corona was seen formed on the fog. At noon snow came on and drifted heavily. At $15^{\text {h }}$ the doorway was blocked at the upper end, and no temperature observation was taken then or at $16^{\mathrm{h}}$; but at $17^{\mathrm{h}}$ a hole was made vertically upwards. By this means the observations were continued, the hole being covered, when not in use, by sacking and boards to keep out drift.

May 11.-Solar halo observed at $10^{\mathrm{h}}$. Well defined; red inside. Radius by stephanome $22^{\circ} 30^{\prime}$. Thermometer box shifted at $19^{\mathrm{h}}$.

May 13. - Faint solar halo, red inside, at $10^{\mathrm{h}}$.

May 18.-At $20^{\text {h }}$ thermometer box was covered with feathery snow crystals, particularly on the upper edge at the west side.

May 19.-At $9^{\text {la }}$ huge masses of cumulus cloud above southern hills. At $14^{\mathrm{b}} 30^{\mathrm{m}}$ thermometer box shifted.

May 22.- In the afternoon a tourist with a horse visited the observatory. 'This was the first horse up this year.

May 23.-At $11^{\text {th }}$ the higher clouds to northward were observed to he whirling round and getting torn to bits. At $13^{\mathrm{h}}$ solar halo observed. Radius about $20^{\circ}$. Colours very brilliant, red inside, blue ontside, yellowish in centre. Horizon hazy, with cumulus above it all day. A robin redbreast seen, singing near the second gorge, from observatory in afternoon. At $19^{\mathrm{h}}$ the N.W. horizon was brownishyellow in colour; and the sea near the Isle of Rum ficry red.

May 24.-Very fine; sky almost clondless, but thick haze all round horizon. Before sunrise and after sunset a dense fog filled the valleys among the more distant hills to north and east.

May 25.-Very fine; but more for hanging about the surrounding hills than yesterday.

I Iay 27. -At $3^{\text {h }}$ the north-eastern sky Green was coloured as in margin. At $10^{\mathrm{h}}$ a green Red belt was seen above the horizon from Haze S.W. to N.W., with dark objects appearing and disappearing in it. Hardly any snow to be seen, except on Ben Nevis, on the flat-topped hill to the eastward, and on the Cairngorms.

Mity 28.-A level sheet of fog filled all the northern valleys, coming as far south as the head of Loch Lochy, from $3^{\mathrm{h}}$ to $9^{\mathrm{h}}$.

Nay 29.-At $9^{\mathbf{h}}$ the large bulb of black bulb was covered with a film of moisture to windward. The readings of dry and wet were 39.7 and 39.1 ; clouds were passing overhead, almost touching the hill.

June 3.-Solar corona at $9^{\mathrm{h}} 5^{\mathrm{m}}$. Red inside, blue outside. After $15^{\mathrm{h}}$ the thermometer box was removed from ladder and placed on wooden stand, 13 inches above snow, while the upper joint of the ladder was taken off. At $16^{\mathrm{h}}$ a fresh box was fixed on remaining part of ladder, 45 inches above snow. At $11^{\mathrm{h}}$ the sky was overcast with stratus, and the clouds were observed to be thinner just above the top of Ben Nevis than elsewhere. 
June 8.-At $23^{\text {h }}$ snow crystals began to form on thermometer box. At midnight lunar corona seen, red outside, with blue margin beyond. Radius of red $2^{\circ} \cdot 30$. Very misty; size apparently varying. N.B. This arrangement of colours probably explains the entry, on June 3 , of a solar corona with blue outside red.

June 9.-At $1^{\text {b }}$ double lunar corona observed. Colours Red ${ }^{2}$ as in margin. The inner one had all the $\begin{array}{ll}\text { Red }^{2} & \text { gradations of spectroscopic colours, the } \\ \text { Blue }^{3} & \text { outer onl bluo and }\end{array}$ Red ${ }^{1} \quad$ outer only blue and faint red. Radius of Yellow inner red ring $2^{\circ}$, outer $4^{\circ}$. When scud Blue ${ }^{1}$ passed over the hill top the corona was 1 hidden. At $2^{\mathrm{h}}$ the inner rings observed as before; lut the outer blue and red were not visible. During the afternoon the whole sky was covered with a pallium of cum.-str. clouds. The horizon was clear, and the sun was seen to be shining on the western sea and islands. Rum, Canna, north-west of MIull, and the Outer Hebrides looked as if they were slightly raised by refraction.

June 10.-At $7^{\mathrm{b}}$ all the surrounding hills were buried in white fog. Cir.-str. seen at $8^{\text {h }} 10^{\mathrm{m}}$ moving from N.W. Mist came on at $13^{\mathrm{h}}$, and lasted till near midnight, when the air suddenly became very dry, with a strong S.W. wind.

June 11.-Short period of cold and drought, with strong south-westerly wind up to $3^{\mathrm{h}}$. Dry and wet at $2^{\mathrm{h}}$ beyond Glaisher's tables. In afternoon James Miller found a flower growing on the rocks at the edge of the north cliff opposite the large cairn.

June 12.-All night the thermometer box was covered with glazing of ice. At $16^{\text {h }}$ the cage for instruments (5 feet high) was seen for the first time this year.

June 13.- Thermometer box shifted at $3^{\mathrm{h}}$.

June 14.-All night the thermometer box was covered with ice crystals.

June 16.-Very misty ; the mist being thicker on sides of hill, but wetter on top.

June 17.-Foggy till $17^{\mathrm{l}} 30^{\mathrm{m}}$, when top cleared, and mist sank below 3000 feet line. All the evening nothing was to be seen except a few hill tops rising through the clouds. This cloud was very level as a whole on its upper surface, but broken into many small billowy ridges. After sunset the sky just above this cloud to N.W. was blood-red, with yellow, green, and blue above. These colours continued all night, following the sun round from N.W. to N.E., and only disappeared at sunrise. At $19^{\mathrm{h}}$ double or triple glories seen at east end of hill top. Colours as in fig. 2. No. 1 was very indistinct, a mere blotch of colour. No. 2 was the brightest of them. No. 3 was not so bright as No. 2, and sometimes was not seen; but, when visible, was quite sharp and distinct.

The following measurements were taken by stephanome.

$\begin{array}{llccc} & & \operatorname{Red}(2) & \text { Blue (2) } & \operatorname{Red}(3) \\ \text { R.T.O. } & 1^{\circ} 55^{\prime} & 1^{\circ} 50^{\prime} & 3^{\circ} 10^{\prime} \\ \text { A.R. . } & 1^{\circ} 55^{\prime} & - & 3^{\circ} 30^{\prime}\end{array}$

The glories were formed on the upper surface of the cloud layer mentioned above.

June 18.- The upper surface of the cloud layer surrounding hill was very level, and it came flush up against the sides of the hill without rising or falling, just like a sheet of water. About $7^{\text {h }}$ this cloud was rising bodily, and just before it reached the level of the hill top a thin wet mist came over the top from the north. At the same time glories were seen. At $8^{\text {h }}$ double fog-bow with faint glory round shadow of observer in centre seen. About $\frac{3}{4}$ of the circles were visible $\left(270^{\circ}\right)$, the rest being cut off by the shadow of the hill. Colours as noted in fig. 3 . The inner (fog) bow was narrower, and not so distiuctly coloured as the outermost. These bows were too large to measure by stephanome; they looked about the size of rainbows.

June 20.-At $15^{\text {h }}$ the hill was surrounded by fog, standing high above the top, but not resting on the sides of the hill. At $23^{\mathrm{b}}$ the sky cleared overhead, the clouds apparently thinning away gradually without moving. June 21.- - Heavy dew and hoarfrost in early morning. June 23 .-At $4^{\mathrm{h}} 15^{\mathrm{m}}$ a 5 -inch rain gauge was put out about 700 inches E.N.E. from cage-- to be read hourly.

June 25.-All the early morning the wind was northerly and pretty strong. Coming up over the cliff it broke into eddies, the back-swirls of which, though not as strong as the true wind, were very distinct.

June 26. - At $20^{\mathrm{h}} 20^{\mathrm{m}}$ top cleared, leaving sky with cum.-str. (10) over it. Dense white fog covered western hills, and filled valleys to $\mathrm{E}$. The sky gradually cleared, but fog came on again at midnight.

June 27.-At sunset the sky was Purple coloured as in margin, with rays shooting Green upwards of pinkish colour to about $20^{\circ}$. Red At midnight the northern sky was still red, Horizon yellow, and green, above the haze. No fog in valleys.

June 28.- Thick haze all round. At midnight the sky was scarcely coloured to the north at all.

June 29.-Though the sky was clear, the sunrise colours were very faint. In afternoon wind blowing up from Glen Nevis formed fog a little below Wragge's well.

June 30.-At midnight observed very low-lying white fog in Glen Nevis.

July 2.-At midnight long streamers radiating from the zenith were observed. They seemed to be composed of filmy cirrus, but looked almost like an auroral arch. They were about $45^{\circ}$ long, and reached from N.E. to W.

July 5.-Lightning at $2^{\mathrm{h}} 25^{\mathrm{m}}$. Needle of indicator moved. Thunder at $2^{\mathrm{h}} 45^{\mathrm{m}}$, and rain at $2^{\mathrm{h}} 48^{\mathrm{m}}$. Lightning again at $22^{\mathrm{h}} 25^{\mathrm{m}}$.

July 11.- Thunder heard at $16^{\mathrm{h}} 15^{\mathrm{m}}$. Hail at $17^{\mathrm{h}} 15^{\mathrm{m}}$, and fog came on for a short time at $17^{\mathrm{h}} 20^{\mathrm{m}}$. Faint badly defined corona at midnight.

July 19. - Small fragment of raiubow seen at $17^{\mathrm{h}}$. This is one of the very few occasions on which a rainbow has been seen from Ben Nevis as yet.

July 20.- Very fine morning, with clear views. The sea below dead calm-detached cumulus above other hill tops. At $9^{\mathrm{h}}$ the formation of this cumulus from fog rising perpendicularly out of the valleys was noted. At $18^{\mathrm{h}}$ rain was seen to be falling at the moor of Rannoch. At $21^{\mathrm{b}}$ ugly heavy cumulus seen to the S.W., and at midnight snow came on.

July 26.-At $10^{\mathrm{h}}$ solar halo observed, colours quite distinct, red inside. Radius of red by stephanome.

$$
\text { Mean, } 22^{\circ} 54^{\prime} \quad . \quad\left\{\begin{array}{lll}
\text { 1st measurement, } & 22^{\circ} 45^{\prime} \\
2 \mathrm{~d} & " & 22^{\circ} 30^{\prime} \\
3 \mathrm{~d} & " & 23^{\circ} 0^{\prime} \\
4 \text { th } & ", & 23^{\circ} 20^{\prime}
\end{array}\right.
$$

July 27.-Fine all day; fog rising from valleys, and forming cumulus above hills. Sea below quite calm. 
$J u l y 28$ - At $21^{\text {h }}$ the sky was covered with a pallium of stratus, and the valleys filled with fog, but to the west there was a distinct edge of light shining between the two layers.

July 31 .-At $23^{\mathrm{h}}$ and midnight rain in curiously large isolated drops.

August 1.-At $2^{\mathrm{h}}$ the top and surrounding hills were clear, but fog lay over the moor of Rannoch. At $4^{\mathrm{b}}$ fog hung in patches on the southern hills, and the clouds seemed to be closing down on Ben Nevis. At $6^{\mathrm{h}}$ light fog was passing over the top, and for the rest of the day it was covered with dense fog or mist.

August 6.-From $22^{\mathrm{h}}$ to midnight the moon shone brightly; the sky under it, down to the haze that hid the horizon, was of a brown colour, similar to the hazy brown colour seen round the sun.

August 7.-At $18^{\mathrm{h}}$ a few drops of "thunder rain" fell.

August 8.-At $20^{\mathrm{h}}$ thermometers 50852 and 50850 were put out in large box (old clock-box), as dry and wet, with max. 117293 and $\min .116918$. At $9^{\mathrm{h}} 45^{\mathrm{m}}$ max. 138590 and $\mathrm{min}$. 138533 were taken in from small box on ladder. At midnight badly defined corona. Faint lightning seen from $23^{\text {h }}$ to $1^{\mathrm{h}}$ on 9 th.

August 9.-Heavy cumulus and haze round horizon all day. At $19^{\mathrm{h}}$ fog came up from Glen Nevis and covered the top.

Greenish August 10. - At $2^{\mathrm{h}}$ a dim lunar corona White observed. Colours as in margin. Cum. Yellow fog at horizon and over lower hills all day.

Red August 12.-At $3^{\text {h }}$ badly defined lunar D corona, red outside. Radius of red $=2^{\circ} 50^{\prime}$.

August 13.-Faint sheet lightning at $1^{\text {h. }}$.

August 17.-In early morning dense fog in valleys; at $8^{\mathrm{h}}$ this fog was observed to be rising and covering the hill tops.

August 20.-At $6^{\text {h }}$ the sky was clear except for some light cirrus; the lower hills almost completely buried in cumulus fog; and the sky, below the sun, of a purple hue.

Aucgust 25.-The two following extra observations were made :-

$\begin{array}{ccccccc} & \text { Bar. } & \text { Dry. } & \text { Wet. } & \text { Wind. } & \text { Force. } & \text { Clond. } \\ 22^{\mathrm{h}} 30^{\mathrm{m}} & 25 \cdot 573 & 32 \cdot 0 & 32.0 & \text { S. E. } & 1 & \text { Mist. }\end{array}$

$\begin{array}{llllll}23^{\mathrm{h}} 30^{\mathrm{m}} & 25.567 & 31.9 & 32.0 & \text { N.NE. var. } 0-1 & \text { Mist. }\end{array}$

At $23^{\mathrm{h}} 30^{\mathrm{m}}$ heavy gusts were heard at the east end of the hill, not coincident with and evidently much stronger than those passing the observatory.

August 27. - At $2^{\mathrm{h}}$ faint aurora observed about $30^{\circ}$ above horizon to westward. At $3^{\mathrm{h}}$ the aurora was flashing all over the western sky. Meteors observed at $2^{\mathrm{h}} 19^{\mathrm{m}}, 2^{\mathrm{h}}$ $23^{\mathrm{m}}$, and at $2^{\mathrm{h}} 12^{\mathrm{m}}$.

$\begin{array}{ll}\text { White } & \text { August } 31 \text { - At } 21^{\mathrm{h}} 12^{\mathrm{m}} \text { a double lunar } \\ \text { Yellow } & \text { Corona and a lunar fog-bow were observed. } \\ & \text { Colours of corona as in margin. Radius }\end{array}$

Red

Blue

Green

Yellow of outer red $=4^{\circ} 32^{\prime}$, inner $=2^{\circ} 15^{\prime}$

Sept. 3.-At $23^{\mathrm{h}}$ a large double lunar corona was observed.

Red Sept. 4.-Thunder was heard at $14^{\mathrm{h}} 4^{\mathrm{m}}$, at $18^{\mathrm{h}} 2^{\mathrm{m}}$, and below in valley to S.E. at $18^{\mathrm{h}} 7^{\mathrm{m}}$. Heavy hail fell at $18^{\mathrm{h}} 32^{\mathrm{m}}$. Meteor seen at midnight.

Sept. 11.-At $1^{\mathrm{h}}$ corona observed. Radius of red ring $3^{\circ} 22^{\prime}$, yellow inside the red ring, and having outside the red a blue margin. This corona was formed on thin scud passing over the hill; the margin was only seen when the scud was very thin.

TRANS. ROY. SOC. EDIN. VOL. XXXIV.
Sept. 13.-At $19^{\mathrm{h}} 20^{\mathrm{m}}$ the sky after sunset was crossed by streamers radiating upwarls, of a mauve colour, and extending to about $30^{\circ}$. Before this there had been merely red, green, and violet above the haze to westward, and a mauve glow to eastward. At $21^{\mathrm{h}}$ aurora observed; siugle arch, no streamers, giving green band in spectrum distinctly. At $22^{\text {h }}$ the aurora had no streamers, but had two pendants hanging from it, sloping westwards. At midnight the lower edge had greatly lost its sharpness of definition, but streamers were rising from the western part of it, to a height of about $60^{\circ}$. 'These streamers appeared to be very long and thin.

Sept. 14.-At $1^{\text {h }}$ the aurora was well defined, with a wavy lower edge. No stieamers, but waves or pulsations of light at intervals. This. continued till $4{ }^{\mathrm{h}}$, after which hour it gradually faded away. Very fine and clear all morning, but with a reddish-brown haze round and under sun, forming a rude corona at times. Beautiful sunset, but no streamers or distinct glow observed. Aurora again visible-at $22^{\mathrm{h}}$ it formed a single well-defined arch, without streamers, but with two bright patches below it in the dark space. For the rest of the night it was seen dimly through fog, and apparently did not alter in character.

Sept. 17.- Meteor seen at $1^{\mathrm{h}} 7^{\mathrm{m}}$, about $40^{\circ}$ above horizon to the S.S.E. In the afternoon glories were seen on the fog in the valley to north. Red outside, with yellow, green, blue, inwards. At times, a faint outer one seen; but they all were too evanescent for measurement.

Sept. 18.-At $1^{\mathrm{h}} 3^{\mathrm{m}}$ A B C telegraph indicator was moved forward four letters. At $10^{\mathrm{h}}$ solar halo with colours observed. Radius roughly about $20^{\circ}$.

Sept. 19.--At $5^{\text {h }}$ the eastern horizon was coloured as indicated in margin. Sun rose at $5^{\mathrm{h}} 55^{\mathrm{m}}$. At $8^{\mathrm{h}}$ red haze round sun of about $20^{\circ}$ diameter. At $9^{\text {h }}$ sky hazy round
Blue

Greenish

Yellow

Dark red

Horizon sun, pale dirty white at horizon, and deep blue at zenith.

Sept. 20.-At $15^{\text {h }}$ glories seen on fog, very similar to those observed on Sept. 17. At about $22^{\mathrm{h}} 5^{\mathrm{m}}$ a large round black cumulus cloud came up from the S.W., with velocity 5, and went almost directly over the top of the hill, spread itself out forming a pallium.

Sept. 22.-Began to experiment with new rain-gauges with opening in side.

Oct. 4.- Fine morning; red and purple colours in sky between sun and horizon. While the moon was partially eclipsed, a strong double corona appeared round it.

Oct. 5.-At $1^{\mathrm{h}} 15^{\mathrm{m}}$ fog-bow, double, observed. Radii approximately $36^{\circ}$ and $32^{\circ}$. At $1^{\mathrm{h}} 30^{\mathrm{m}}$ triple corona observed. Radius of 1 st ring, $2^{\circ} 0^{\prime} ; 2$ nd, $3^{\circ} 5^{\prime} ; 3 \mathrm{rd}, 4^{\circ} 20^{\prime}$. These numbers are only rough. All day the lower hills were buried in a level sheet of fog. Reddish haze under sun and moon. Beautiful sunset. Meteor seen to S.E. at midnight.

Oct. 6.-At $6^{\mathrm{h}}$ eastern sky colnured as Pink indicated on margin. Day very quiet and Pink streamers warm. After sunset, at $18^{\text {h }}$, orange, yellow, Pale green green, and pink colours to westward. Some Red-orange-red streamers in the pink. At $19^{\mathbf{b}}$ dark red and pale green showing. Apparently no afterglow. At $14^{\mathrm{h}}$ a wasp was seen on the top.

Oct. 12.-Lunar corona at $5^{\text {h }}$ Colours Blue as in margin. The outer blue in coronas of Red this type forms a distinct margin or glare. D

$3 \mathrm{R}$ 
This corona was formed on passing fog and scud; its size appeared to vary.

Oct. 16.-At $1^{\text {b }}$ bright light seen low down to northward; might be aurora, but no green line was visible in spectrum.

Oct. 24.-At noon sky to N.W. dirty yellow, at $13^{\text {h }}$ greenish and brown, and at $14^{\mathrm{h}}$ bright red. At $19^{\mathrm{h}}$ faint lunar corona visible.

Nov. 1. - At midnight the clouds above the lill had a very misty look, and seemed to hang down clear of the hill on each side.

Nov. 3.-At $11^{\mathrm{h}}$ fog-bow observed with colours, red inside.

Nov. 7.-At midnight faint misty corona observed ; red outside. Diameter of red $=5^{\circ}$.

Nov. 10.-At $15^{\mathrm{h}}$ there was heavy cumulus round horizon, but no fog in valleys. Near the sun the sky showed a brown glare, while the northern sky was pale green. At $22^{\mathrm{h}} 10^{\mathrm{m}}$ clouds were observed blowing across from the southern hills, but vanishing before they reached Ben Nevis.

Nov. 13.-At $6^{\text {h }}$ faint corona seen, no distinct colours, but a faint red ring with white inside and blue out. At noon glory and fog-bow seen in valley to northward. Sky beneath sun at noon bright yellow. At $19^{\text {h }}$ dark belt all round horizon about $5^{\circ} \mathrm{high}$, darkest to westward; the rest of the sky milky looking.

Nov. 14. - At $7^{\text {h }}$ the eastern horizon was brightly coloured; the order of colours being, red and yellow to about $3^{\circ}$ above horzion, green $11^{\circ}$, blue $50^{\circ}$. The sky to the west being of a faint purple hue. Among these colours were streaks of filmy cloud; sky otherwise clear. Three times, at intervals of about 5 minutes, a very small cloud shot up from the horizon to E.S.E. like a puff of smoke from an engine chimney, and then fell and disappeared. At $7^{\mathrm{h}} 40^{\mathrm{m}}$ the colours to E.S.E. got watery looking, the streaky clouds increased, and the sky for about $8^{\circ}$ above the yellow part was almost white. At $7^{\mathrm{h}} 44^{\mathrm{m}}$ a purplish-pink arch appeared to the W.N.W. The arch was about $7^{\circ}$ broad, and clear space underneath, some $5^{\circ}$, was pale sea-green in colour. It lasted till the sun

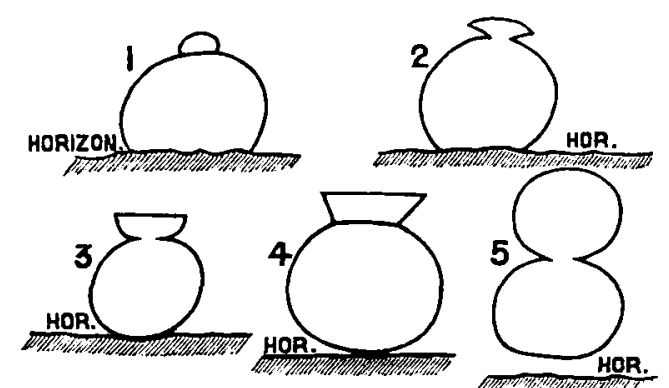

rose. As the sun rose, it took the above forms in succession, as it passed through the streaks of cloud. The streaks of cloud were invisible, except when brought out by the sun and the colours in the sky. At $8^{\mathrm{h}}$ the sky under the sun was brick-red in colour, in the forenoon the sun was surrounded by a dusty looking red corona, the inside radius of which was about $11^{\circ}$. At $11^{\mathrm{h}}$ this corona had a white watery look inside between the reddishband and the sun. The haze under the sun was brickred. At sunset the sun had a flat-topped look while passing under the horizon, the northern limb being slightly higher than the other. A distinct pink afterglow was observed on cirrus clouds. At $18^{\text {h }}$ there was still a white glow to W. At $19^{\text {h }}$ fog was on hill top, and sky obscured.

Nov. 15.-Light fog on hill top in early morning, clearing off about sunrise, but leaving detached patches on hills round. At $7^{\mathrm{h}} 20^{\mathrm{m}}$, before sunrise, pink streamers appeared to S.E. Just above a heavy cloud bank there was, first a narrow belt of red, then a patch of yellow and orange, above that dirty green colour. The streamers shot up through this, apparently sloping towards the observer. The sky at zenith was deep blue, while to westwards there was a watery pink glow. As the sun rose it assumed these forms. These figures are copied from tracings

made by focussing the sun's image on a sheet of paper from a telescope, and pencilling the outline.

Nov. 21.-At noon the sky was pretty clear (cum.-str. 4), but fog low down all round. The movements of this fog showed a descending current on the south side of Ben Nevis, and an ascending to westward out of Glen Nevis. Wind, $N$. and E., force 4 to 5 . At $19^{\mathrm{h}}$ the moon was shining through haze to S.W., looking very red, and with a glare like what surrounded the sun during the day.

Nov. 23.-At $6^{\text {b }}$ faint glow to S.E. near horizon. At $7^{\mathrm{h}}$ yellow, green, blue, and violet coluurs at S.E. horizon. At $8^{\text {h }}$ still bright colours to S.E., and splendid sunrise. At $9^{\text {h }}$ glories observed on fog to N., apparently about 2 miles distant, showing five red rings. These continued all day, the number of rings varying from 3 to 5 (see fig. 4). At $14^{\mathrm{h}}$ measurements were taken-1st red, too small to measure ; $2 \mathrm{nd}, 2^{\circ} ; 3 \mathrm{rd}, 3^{\circ} 15^{\prime} ; 4$ th, $4^{\circ} 50^{\prime} ; 5$ th, too faint to measure. The 1st ring was blurred and indistinct-looking. The 5th ring was incomplete, and very faint. In each ring red outside and blue inside. At $8^{\text {h }}$ church bells (? Fort William) were heard from top of tower. At noon the red haze under the sun to the form of a crude partial halo. Radius of inner side, $10^{\circ} 40^{\prime}$; of outer, $23^{\circ} 30^{\prime}$. At $14^{\mathrm{b}}$ the level top of the fog round the hill was at about 3000 feet. By $15^{\mathrm{h}}$ it had risen almost the height of Ben Nevis. Very little colour in western sky at sunset, and no afterglow. A faint light observed to $\mathrm{N}$. at night, which might be auroral ; but no green line was visible in spectroscope.

Nov. 24.-At $6^{\text {h }}$ faint glow to ES.T Purple At $7^{\mathrm{h}}$ colours above cloud bank at horizon Green as in margin. At $8^{\mathrm{h}}$ sky and clouds to Yellowish N.W. pink. At $7^{\mathbf{b}} 14^{\mathrm{m}}$ while Mr Rankin green was looking out of the tower door with a Yellowish red telescope, and steadying it by holding it up Horizon against the wooden framework of the tower, he felt several distinct shocks or tremors, more intense than and of a different character from the vibrations caused by wind. No noise was heard outside, but a faint rumbling in the 
wood-work of the tower. It seems to have been due either to earthquake or to the tower settling a little.

Nov. 26.-Thermometer box shifted at $17^{\mathrm{h}}$. At $23^{\mathrm{h}}$ the snow post near rain-gauge (A) was found to be thickened by snow crystals to a size of about 20 inches by 12. [The size of the post is 7 inches by 3.]

Nov. 29.-At $2^{\mathrm{h}}$ small corona seen. Very yellow looking, inside red, with blue margin outside. Radius of red $1^{\circ} 55^{\prime}$. At $16^{\text {h }}$ fog all over northern hills, but visibility to southward. Sky faintly red to S.S.W., yellow and pale green to S.W., and dark to E., which might be earth shadow. No afterglow. At $17^{\mathrm{h}}$ moon was shining brightly, with under it a reddish-brown haze. At $18^{\mathrm{h}}$ faint blue corona round moon. At $22^{\mathrm{h}}$ corona with bluo margin, colours inside red, not distinct. Radius of red, $1^{\circ} 55^{\prime}$. The outer blue not always seen. At midnight very faint halo.

Nov. 30.-At $1^{\text {h }}$ faint halo, no colours, inside radius roughly $18^{\circ} 20^{\prime}$ by stephanome-probably halo of $22^{\circ}$ radius. White snow crystals forming rapidly all afternoon.

Dec. 1.-Corona with red outside, but blue margin, formed on scud passing over hill. Radius of red, $4^{\circ}$; space inside red blue looking. When the scud clears off, this corona disappears, but the moon is seen surrounded by a very much smaller one, very yellow looking inside the red. At $3^{\mathrm{h}}$ misty corona formed on scud. Red outside. Radius of red, $2^{\circ} 52^{\prime}$.

Dec. 4.- At $1^{\text {h }}$ corona. Red outside. Radius of red $2^{\circ}$. Blue margin seen at times.

Dec. 5.-At noon sky watery-looking round sun, and red and yellow in colour under it. Horizon dark blue to N.W. At $15^{\text {h }}$ thermometer box shifted.

Dec. 11.-The snow post at Wragge's hut, after being covered with snow crystals, got glazed over by rain falling while the temperature was below $32^{\circ}$. The top was covered by an umbrella of snow about 15 inches thick by 40 to 50 inches across. The diameter of the shaft was about 20 inches, and the height 100 inches; the post itself measures only about 6 inches by $2 \frac{1}{2}$.

Dec. 17.-The suow near the Observatory was observed to be lying in waves with some 50 or 60 inches between the crest, the line of crests running perpendicular to the wind.

Dec. 20.-At $3^{\mathrm{b}}$ thermometer box shifted.

Dec. 21 .-At $16^{\mathrm{h}}$ a heavy bank of cumulus hid the afterglow, but some cirrus clouds to N.E. had a pale red glow on them. At $16^{\mathrm{h}} 25^{\mathrm{m}}$ the cumulus cloud was almost gone, and a glow visible, extending downwards till it met the ordinary sunset colours. The moon was pale green in colour. The glow lasted till shortly after $17^{\mathrm{h}}$.

Dec. 22. - Fine sunrise. At $7^{\text {h }}$ a pale green band appeared just above S.E. horizon. At $8^{\text {h }}$ sky to W. purple, with dirty sea-green under it, while to E. and S.E. it showed bright red, yellow, and purplish pink. After $8^{\mathrm{h}}$ this red and yellow extended in both directions, forming a coloured horizon all round; above this the sky was whitish green, and above that again was a band of pink, showing all round, but most brightly to N.W. These belts extended to about $15^{\circ}$ above the horizon all round. The zenith was blue. The sun rose at $8^{\mathrm{h}} 42^{\mathrm{m}}$, and these colours faded away, leaving a hazy red and yellow all round horizon. Before the sun rose the snow on the hills to $\mathrm{N}$. and N.W. was smoky green in colour, when contrasted with the snow on Ben Nevis. The sky was cloudless down to the horizon. At $10^{\mathrm{h}}$ hazy red corona round sun. This continued most of the afternoon. At $16^{\mathrm{h}} 30^{\mathrm{m}}$ there was a very faint pink glow to N.W. on cirri clouds, the sky below being bright red and yellow. At $20^{\mathrm{h}}$ and $21^{\mathrm{h}}$ aurora observed, single arch, stretching from W.N.W. to N.N.E. No streamers; height of top of arch about $20^{\circ}$. At $22^{\mathrm{h}}$ the eastern part of the arch had a wavy or toothed structure below.

Dec. 23.-To-day the feathery snow crystals, forming on exposed surfaces, were grey-brown in colour.

Dec. 24.-The snow crystals forming to-day are white in colour, and contrast strongly with those of yesterday.

Dec. 25.-Before sunrise (at $8^{\text {h}}$ ) sky dirty green to S., with pale yellow above, and a faint pink tint on cirrus clouds. At $10^{\text {h }}$ the sky below the sun was red. At $11^{\text {h }}$ triple glories seen to northward. Very faint rosy corona round sun at noon. At $16^{\mathrm{h}}$ very thin scud was passing across the hill, which "glowed" with the same colour as the usual sky afterglow. At $16^{\mathrm{h}} 25^{\mathrm{m}}$ distinct patch $^{\text {to }}$ of afterglow. Other colours as indicated in margin. At $16^{\mathrm{h}} 40^{\mathrm{m}}$ the glow was gone, and the sky coloured orange Pog were hid in level-topped fog, rising to about 3000 feet. At $17^{\text {h }}$ lunar corona observed. Very misty. Radius of red, $2^{\circ}$ to $3^{\circ}$. Very green and yellow in appearance. No blue, and red faint. At $20^{\mathrm{h}}$ very faint blue corona round moon. No other colour visible; the radius of blue about $2^{\circ} 5^{\prime}$. At $22^{\mathrm{h}}$ small corona. Red, too small to measure, with yellow inside it. Blue extending to about $3^{\circ} 10^{\prime}$ radius. At $23^{\mathrm{h}}$ there was no corona, but a slight darkening of tho sky under the moon. At midnight corona without blue margin. Radius of red, $2^{\circ}$.

Dec. 26.-At $8^{\text {h }}$ the S.E. horizon was of a bright golden colour. The valleys were filled with fog, not rising higher than 2000 feet. At $9^{\mathrm{h}}$ a raven was seen near the second gorge. At $13^{\mathrm{h}}$ solar fog-bow, and at $22^{\mathrm{h}}$ lunar fog-bow, observed ; too large for stephanome.

Dec. 27. - In the middle of the day dense fog over all the lower hills, rising nearly to the height of Ben Nevis, say about 4000 feet. Also brown colour under sun. Sunset colours faint. No afterglow. At $18^{\mathrm{h}}$ luuar corona ubserved. Colours as in margin. Radius of blue $1^{\circ} 50^{\prime}$; radius of $\operatorname{red}^{2}, 2^{\circ} 25^{\prime}$; radius of $\mathrm{red}^{3}, 4^{\circ} 30^{\prime}$. At $17^{\mathrm{b}}$ very faint lunar halo seen. At $20^{\mathrm{h}}$ lunar corona with colours as in $\operatorname{Red}^{3}$ margin. Outer red, rather faint. Radius Blue of red $^{1}, 2^{\circ} 2^{\prime}$; radius of red $^{2}, 4^{\circ} 5^{\prime}$. At Red $^{1}$ $21^{\mathrm{h}}$ double corona still seen. Its size Yellow appeared to vary, being small when the

Red $^{3}$

Blue ${ }^{3}$

Red ${ }^{2}$

Blue ${ }^{2}$

Whitish

$D$ sky was clear of low clouds, and enlarging as the scud passing over the hill thickened.

Dec. 28.-At $10^{\mathrm{h}}$ lower hills buried in fog to about 3000 feet. By noon the fog was broken up into detached pieces in the valleys, and mixed with haze-copper colour under sun all afternoon. At sunset sky was orange and yellow to S.W., and blue-black to N.E. No afterglow. At $21^{\mathrm{h}}$ the moon was surrounded by a white glare of about $5^{\circ}$ radius. No halo or corona. This glare lasted all night, but at $23^{\mathrm{h}}$ and midnight there was also a faint blue corona. 
No other colours visible. Outside radius, $3^{\circ} 25^{\prime}$. The glare at the same time had increased to about $15^{\circ}$ radius.

Dec. 29. -At $3^{\text {h }}$ the sky under the moon was copper coloured. Corona at $20^{\mathrm{h}}$ red outside. Radius of red, $3^{\circ} 28^{\prime}$.
At $23^{\text {h }}$ double corona, colours as in margin. Outer red very faint. Rather misty looking, the size appeared to vary. Radii of inner red, by stephanome, $3^{\circ} 40^{\prime}$ and $3^{\circ} 55^{\prime}$.

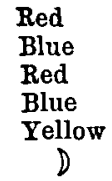

\section{5 .}

Jan. 1.-Snow crystals forming all day at from 1 to 2 inches per hour. The tower chimney was several times choked by crystals forming under the small inside cowl.

Jan. 2.-Very wild sunrise. At $8^{\text {th }}$ the S.E. horizon bright red and yellow, with cir.-str. above tinged with brown-red on lower surface. At $9^{\text {h }}$ this colour or glow had disappeared, except to N.W. ; the sun was about $5^{\circ}$ above horizon, clouds dense and watery.

Jan. 8.-At $2^{\text {h }}$ rain-gauge not found, probably blown over the north cliff.

Jan. 11.-At $9^{\text {h }}$ rain-gauge blown away. At $11^{\text {h }}$ thermometer box shifted. The snow drift blown up the cliff near the plateau of storms was seen to rise from 100 to 200 feet in the air, and pass away to leeward in clouds, resembling ordinary small scud clouds.

Jan. 12. -Thermometer box shifted at $14^{\mathrm{h}}$.

Jan. 14.-Bright sunrise colours, but no upper glow in sky. At $10^{\text {h }}$ hazy rosy corona at sun. At $16^{\text {h }}$ E. sky showed colour like afterglow. At $18^{\text {b }}$, however, there was a faint red and pale green glow above western horizon.

Jan. 15.-Besan to use new pattern rain-gauges. No upper glow at sunrise. During the day brown haze round sun, strongest below it. At $16^{\mathrm{h}} 30^{\mathrm{m}}$ no afterglow to W., but faint glow to E.N.E. At $6^{\mathrm{h}} 40^{\mathrm{m}}$ the western afterglow began, and the eastern glow disappeared. At $6^{\mathrm{h}}$ $50^{\mathrm{m}}$ the afterglow was distinct to westward. At $7^{\mathrm{h}}$ it was fading.

Jan. 19.-At $17^{\mathrm{b}}$ (after sunset) red, yellow, and green to westward. No upper glow. At $18^{\mathrm{h}}$ pale blue glow to westward. At $19^{\mathrm{h}}$ pale blue glare round moon.

Jan. 20. - In morning, fog all over lower hills. At $8^{\text {h }}$ bright pink upper glow above red, and yellow colours to S.E. At $10^{\mathrm{h}}$ and $11^{\mathrm{h}}$ red haze below sun, and white glare round it. At $12^{\mathrm{h}}$ hazy red corona round sun, with white watery looking core. The red or copper colour under the sun got fainter in the afternoon. No afterglow atsunset.

Jan. 21.-Sunrise colours very bright, but no upper glow. Copper haze at sun all day. Passing fog prevented sunset from being observed, but apparently there was no afterglow.

Jan. 23.-Valleys filled with haze, rising to a definite level. At $18^{\mathrm{h}}$ lunar corona observed, red outside. Radius of red, $2^{\circ} 36^{\prime}$. Again at $23^{\text {h }}$ faint misty blue look round moon, no other colours.

Jan. 24.-At $22^{\text {b }}$ faint misty corona, red outside. Radius of red, $2^{\circ} 30^{\prime}$.

Jan. 29.-At $1^{\text {h }}$ and $2^{\text {h }}$ very small misty corona. At Red $\quad 4^{\text {b }}$ misty corona. Colours as in margin. Blue Outer red very faint, making the blue look Red

Yellow more like the margin often seen, than a

D part of corona proper. Radius of inner red bluish corona formed on scud.
Jan. 31.-Both to-day and yesterday thermometer box badly choked with fine drift.

Feb. 2.-Thermometer box shifted at $14^{\mathrm{h}}$. At $22^{\mathrm{h}} \mathrm{St}$ Elmo's fire observed on tips of lightning rod; each ti ${ }^{\prime}$ having a spark like a match when just struck on it.

Feb. 4.-At $7^{\mathrm{h}} 5^{\mathrm{m}}$ double corona observed. Colours as in margin. Radius of inner red $=2^{\circ} 36^{\prime}$, onter red $=5^{\circ} 10^{\prime}$. At $8^{\mathrm{h}}$ upper glow to S.E., forming an arch with a watery core; the arch measuring about $14^{\circ}$ inside radius, and $30^{\circ}$ outside, by stephanome, and being Red Blue Red White space D coloured the usual pinkish brown hue. At $10^{\mathrm{h}}$ rosy corona round sun.

Feb. 6.-Drift very bad all day. At $14^{\text {h }}$ a wave of drift had formed between the thermometer box and the tower-the box was half buried, although at $13^{\mathrm{h}}$ it had been 30 or 40 inches clear of the snow. The front of the wave formed a steep bank, almost vertical, about 30 inches high, which in the afternoon gradually advanced almost to the tower. At $14^{\mathrm{h}}$ the rain-gange was also buried with 6 or 7 inches of snow over it.

$F e b .7$.-As the thermometer box was on the highest joint of the ladder stand it could not be shifted till $17^{\mathrm{h}}$ to-day, when the wind having moderated, an extra joint was fixed to ladder, and the box set 50 inches above snow. Feb. 8. -At $14^{\text {h }}$ barometer pumping with long slow motion, falling during gusts.

$F e b .9 .-$ At $7^{\text {h }}$ double corona in cloudless sky. Inner ring too small for stephanome, and outer too faint. At $9^{\text {lh }}$ thermometer box shifted.

Feb. 10.-In morning snow crystals white, but at $17^{\mathrm{h}}$ brown ones began to form.

Feb. 16. - At $5^{\text {b }}$ four lighthouses seen; probably Barra Head, Dhuheartach, Fladda, and one to the east of Jura, not identified. At $6^{\mathrm{h}}$ a cone or triangle of green light was seen to eastward, rising to about $30^{\circ}$ from a base reaching from N.E. to S.E. Air very clear all morning. At $9^{\mathrm{h}}$ copper colour under sun. At $10^{\mathrm{h}}$ Beauly Firth seen distinctly. The copper colour at the sun formed a rude corona. Sun set at about $17^{\mathrm{h}} 34^{\mathrm{m}}$; the sunset colours were weak, but the sky above them was smoky green, while to eastward it was deep blue. No afterglow, except at $20^{\mathrm{h}}$, when a faint white glow was seen to westward, possibly the zodiacal light. Faint badly defined aurora at night.

Fel. 17. - Sky very hazy and watery in early morning. No upper glow before sunrise. Fog came on during the day, occasionally rising and forming a pallium overhead.

Feb. 18. - Faint copper colour below sun all day. At $23^{\mathrm{h}}$ and midnight faint auroral arch from N.E. to W.N.W., badly defined, no streamers.

Feb. 19.-At $21^{\text {h }}$ lunar corona observed. Blue Colours as in margin. Radius of red, Yellowish $2^{\circ} 30^{\prime}$. 
Feb. 20.-Sunrise colours rising to about $10^{\circ}$ at $7^{\mathrm{h}}$, with purplish band above them. The snow drift to-day formed waves or rolls. At $21^{\mathrm{h}}$ small yellow corona, with blue margin, the margin being faintly tinged with red. Radius of this red, $4^{\circ} 3^{\prime}$.

$F e b .21$.-At $13^{\text {h }}$ rain-gauge found blown away to near the edge of the cliff, not put out again to-day. At $16^{\mathrm{h}}$ the note-book for the observation was torn in two and blown away. After $17^{\mathrm{h}}$ no temperature readings were taken, as the lamps could not be kept alight, and the observers could not stand against the wind. At $18^{\mathrm{h}}, 19^{\mathrm{h}}$, and $20^{\mathrm{h}}, \mathrm{Mr}$ Omond or Mr Rankin went out at the tower door with a long rope and had to be hauled back. After that the observer did not go out. At $22^{\mathrm{h}}$ the outer glass of south window in tower was seen to be broken, probably by a flying piece of ice, many of which were heard rattling on the tower like stones.

$F e b$. 22.-First temperature reading taken at $8^{\text {h }}$. Box found badly choked with drift, and with about half its back outer louvres smashed. The top joint of snow post A was also broken. The snow was much blown away by the wind, the general height being lowered several inches - even the moderately hard crust on top was broken up. The fog crystals, formed during the storm, were very long and somewhat hard and icy in texture.

Feb. 23.-Thermometer box shifted at $14^{\mathrm{h}}$. At $19^{\mathrm{h}}$ Bluish pink faint corona formed on upper clouds. One
Yellow

$\begin{array}{ll}\text { Yellow } & \text { red ring, rather broad. Radius inside, } \\ \text { Pink to violet } 1^{\circ} \mathbf{4 5 ^ { \prime }} \text {; outside, } 2^{\circ} 40^{\prime} \text {. }\end{array}$

Blue Feb. 28.-Thermometer box shifted at

Yellow (pale) $14^{\mathrm{h}}$. Solar corona seen by Mr Rankin

Whitish yellow from plateau of storms at about $16^{\mathrm{h}} 15^{\mathrm{m}}$. Formed on scud. Colours as on margin.

Mar. 1.-At $3^{\mathrm{h}}$ lunar corona. Colours as in margin. Red 2 Formed on scud. Radius of inner red, Orange $\quad 3^{\circ} 18^{\prime}$; outer red, $4^{\circ} 49^{\prime}$. At $4^{\mathrm{h}}$ brown Greenish blue glare under moon, and very faint blue Red $^{1}$ corona. At $7^{\mathrm{h}}$ the sunrise colours appeared Yellow very dusty looking. Sky hazy all morning. White Solar halo at $14^{\mathrm{h}} 23^{\mathrm{m}}$, faint red inside, radius Dabout $18^{\circ}$. No sunset colours observed.

Mar. 2. - Snow crystals to-day, greyish in colour.

Mar. 3.-Snow crystals, still grey in colour.

Mar. 4.-Snow crystals, usual white colour.

Mar. 5.-All afternoon canopy of cloud over hill top, but sun shining on lower hills round. Snow line distinct at about 2000 feet. At $22^{\text {h }}$ thermometer box shifted. sky.

Mar. 6.-Clear views round all day. Copper colour in

Mar. 8.-At $11^{\mathrm{h}}$, when sun was behind large cumulus cloud, strong copper-coloured glare round it, in sky, not on the clond itself.

Mar. 9.-Horizon very clear in middle of day; no fog in valleys; hazy glare round sun, and faint copper colour in sky.

Mar. 13.-At $10^{\text {h }}$ columns of cloud observed ascending from above the valleys to southward, and mixing with the cloud above. Lochiel dead calm all morning. In afternoon haze at horizon, but no fog in valleys. At $16^{\mathrm{h}}$ haze was dark brown to $\mathrm{E}$. and N., but milk-white, like cloudy milk and water, under the sun to S.W. It was cut off by a sharp line on its upper surface all round; above this line to S.W. the clouds were of a faint brown colour. At $18^{\mathrm{h}}$ smoke of burning heather, near upper Lochiel, showed N.W.

TRANS. ROY. SOC. EDIN. VOL. XXXIV. wind. No afterglow at sunset; only dirty yellow, and faint red above haze. From $9^{\text {h }}$ to midnight faint whitish light to northward, not auroral, apparently.

Mfar. 14.-At $6^{\text {h }}$ thick haze all round horizon, the eastern sky a blaze of red, scarlet, and yellow. The sun rising through the haze was much elongated horizontally. During the forenoon the haze had a distinct sharp upper edge; under the sun it was whitish blue in colour, but elsewhere dark. Copper coloured corona round sun. At $10^{\mathrm{h}}$ the haze was mixed with fog. By $12^{\mathrm{h}}$ it had risen to the level of the top of Ben Nevis, and all afternoon the hill top was covered with fog.

Mar. 15. - In forenoon grey snow crystals forming on exposed surfaces. In afternoon thick haze, mixed with cumulus fog, at horizon; dark in colour, except to S.W., under the sun, where it was blue-white.

Mar. 18. - All yesterday and this morning the thermometer box was badly choked with hard ice. It was shifted at $14^{\mathrm{h}}$.

Mar. 20.-Wind very gusty all day, blowing in great swirls, especially at night. At $10^{\text {h }}$ straws and pieces of fern observed flying about on the hill top. Ice forming all day on all exposed surfaces, but not in regular definite crystals.

Mar. 21.-At $17^{\mathrm{h}}$ a large bird, probably a kite, was seen flying above the hill top. At $20^{\mathrm{h}}$ lunar halo observed. Radius by stephanome, $23^{\circ} 15^{\prime}$.

Mar. 22.-Faint brown colour in sky near sun in afternoon; clear views, except where clouds hung lower than the hill top. At $18^{\text {h }}$ the str. and cum. clouds were of a dusky yellow hue. At $19^{\mathrm{h}}$ sky cloudy to westward, but under it horizon yellow with pale green above. The under edges of the clouds purple, and Lochs Eil and Red Linnhe green in colour. At $20^{\mathbf{h}}$ still faint Blue red to westward. Double corona round Red moon. Colours as in margin. Radius, Watery yellow inner red, $1^{\circ} 53^{\prime}$; outer red, $4^{\circ} 40^{\prime}$. It $D$ was formed on passing cloud, but when the sky was clear a faint blue glare surrounded the moon. Thermometer box shifted at $22^{\text {h }}$.

Mar. 23.-At $6^{\mathrm{L}}$ no upper glow, but cirrus clouds all of reddish purple in colour. The sun as it rose was greatly distorted. Brown haze in sky under sun all forenoon, v. to N. and E., but haze gradually coming up from S.W. At $11^{\mathrm{h}}$ cirrus clouds lying W.S.W. and E.N.E., but moving from $W$. to $E$. In the afternoon, while sun was obscured by clouds, ice formed on the cardboard of sunshine recorder in the focus of the lens.

Mar. 24.-At $23^{\mathrm{h}}$ sky cloudless, but fog still covering the east end of the hill. Thermometer box shifted at $23^{\mathrm{h}}$ $18^{\mathrm{m}}$.

Mar. 25.-Haze, mixed with increasing amount of fog, came on from western horizon in early morning. At $6^{\mathrm{h}}$ eastern horizon red and bright yellow; under surfaces of upper clouds of a soft reddish hue. At $14^{\mathrm{h}}$ the paper of notes for the hour was torn in two by the wind, half of it being blown clean away out of the book.

Mar. 26.-At $21^{\mathrm{h}} 15^{\mathrm{m}}$, when preparing daily report for newspapers, found that communication by the cable was broken. Tested the wires inside the Observatory, and found them all right, but no signals could be got from Fort William all night.

Mar. 27. - At about $6^{\mathrm{h}} 50^{\mathrm{m}}$ telegraph cable tested, and found to be working all right; the signals to and from 
Fort William being perfect. Thermometer box shifted after $18^{\mathrm{h}}$ observation.

Mar. 29.-From $21^{\mathrm{h}}$ yesterday to $7^{\mathrm{h}}$ to-day no gauge was out, the quantity of drift flying about making its indications useless. At $21^{\mathrm{h}}$ to-day the door of thermometer box was found standing open. At $23^{\text {h }}$ the sky to northward broke a little, showing blue sky.

Mar. 30.-Haze round horizon, and in valleys all day, but without any definite marked upper limit. Brownish colour near sun, getting fainter in afternoon. Thermometer box shifted after $9^{\mathrm{h}}$. Lunar halo at $22^{\mathrm{h}}$ on cirrus clouds. Radius by stephanome, $18^{\circ}$. At $23^{\mathrm{h}}$ very faint brown colour under moon.

April 1.-After $9^{\mathrm{h}}$ observation thermometer box was shifted. At $10^{\mathrm{h}}$ faint purple corona round sun.

April 4.-At $8^{\mathrm{h}}$ the sunshine recorder was found buried in drift. Ice formed, in focus, on cardboard all day. Thermometer box shifted at $14^{\mathrm{h}}$. Light dry drift, rising to some 5 or 6 feet only, was blowing about thickly all day. Faint copper colour in sky near sun in afternoon: dense haze mixed with cumulus at horizon, and filling valleys. No sunset colours, except a faint dirty yellow at western horizon.

April 5.-No rain-gauge was out to-day, as the high wind cutting away the surface of the snow made it dangerous to expose it, but no snow was observed falling. In the morning the fog-crystals were grey, but later were of the usual white colour, and very loose in texture.

April 6.-Fog crystals white, forming freely all day. No gauge was out, but no snow was observed falling.

April 7.-All the daytime great masses of cumulus hung about the hill, and at the horizon. At $18^{\text {h }}$ red haze to westward; radiating beams from sun coming out under cloud. Wind on Locheil, N.E.

April 8.-At $2^{\mathrm{h}}$ pillars of white light observed to N.W., rising above dark haze or cloud bank. At $4^{\text {h }}$ horizon to E.N.E. faintly red, with pale green sky above. Solar halo at 10 and $11^{\mathrm{h}}$. Red inside. Radius by stephanome (doubtful observation), $25^{\circ} 50^{\prime}$. At $11^{\mathrm{h}}$ the top and bottom of the halo were brighter than the sides. Haze at horizon in afternoon; copper coloured to westward, but bluish looking elsewhere. At $23^{\mathrm{b}}$ faint white light to northward, seen through fog.

April 13.-At $4^{\mathrm{h}}$ very clear, with delicate sunrise (Cloud) colours, to N.E. At $5^{\text {h }}$ colours of eastern Green sky as in margin. At $8^{\text {h }}$ faint copper Yellow colour in sky under sun. At $20^{\text {h }}$ thin Red greenish haze over Loch Linnbe, blood-red Horizon streak under clouds to W.N.W.

April 14.-Pallium of cum.-str. all day, not extending far to eastward, however. Horizon and valleys got very hazy in afternoon.

April 15.-Sky completely overcast with pallium of cum.-str. till $20^{\mathrm{h}}$, when an easterly breeze sprang up, and the sky cleared; heavy densely packed clouds all round to westwards.

April 16.-At $14^{\text {h }}$ Robinson anemometer was cleared of snow. Readings were taken between $17^{\mathrm{h}}$ and $19^{\mathrm{h}}$. At $20^{\mathrm{h}}$ the instrument was very stiff, and could not be moved by the light winds which prevailed.

April 17.-Sky remained cloudless till just before sunrise. At $4^{\mathrm{h}}$ sky was dark red on eastern horizon, with greenish tints above. 'Two long shafts of stratus cloud stretched from about N.E. to S.E. pretty low down, and filmy cirrus clouds appeared. At $6^{\text {h }}$ faint solar halo was observed, which vanished at $6^{\text {h }} 10^{\mathrm{m}}$, except two very bright spots with red towards sun, one on each side of sun, and at the same height above the horizon. Stephanome gave radius of $24^{\circ}$. At $7^{\text {h }}$ faint halo was again observed ; at $8^{\mathbf{h}}$ the highest part appeared brightest, and at $9^{\mathbf{h}}$ only that part remained visible. At $11^{\mathrm{h}}$ the balo had entirely disappeared. At $13^{\text {h }}$ the halo was again visible, and five observations gave $22^{\circ} 45^{\prime}$ (doubtful), $23^{\circ}$ $40^{\prime}, 22^{\circ} 15^{\prime}, 23^{\circ}, 22^{\circ} 15^{\prime}$, of red ring (inside) as radius. Thick haze lay on the surrounding hills nearly all day. At $18^{\text {h }}$ this was of a blue colour, except to westwards, where it was yellowish. At $19^{\text {h }}$ the western horizon presented a very wild appearance, the lower clouds moving very fast, and having very ragged edges. Robinson anemometer was cleared again at $8^{h}$, and continued working throughout the day.

April 19.-Wind strong at night, with considerable drift. Rain-gange taken in at $21^{\mathrm{h}}$, being filled with drift. Put out at midnight, when rain began to fall.

April 20.-At $15^{\text {h }}$ it was found that the solder of the connecting wire, joining the Robiuson anemometer with the revolution counter, had given way. As the weather looked rather threatening, it was not repaired.

April 21.-Rain till $16^{\mathrm{h}}$. Snow thawing fast. Roof of Observatory was visible near tower in the morning.

April 23.--Robinson anemometer repaired. Hills very clear in the afternoon. Cumulus clouds hanging only a shor't distance above top of Ben Nevis, and spreading in level sheet all round. Thermometer box shifted at noon.

A pril 28.-Thermometers changed at $5^{\mathrm{h}}$. Sky very wild at sunrise, fiery red to eastwards low down, with dense black cumulus to westward. In afternoon the ice crystals, forming from the fog, were at times of a very dark grey colour, occasionally almost black. These were overlaid with pure white.

April 29.--Robinson gave way again in same way as before. Not repaired.

May 4.-At $20^{\mathrm{h}} \mathrm{v}^{2}$ to northwards and north-westwards below heavy cumulus clouds. Sun set behind Skye Hills. Single streamer, rising almost vertically up above cumulus, visible against some thin cirrus which began to form about $20^{\mathrm{h}} 10^{\mathrm{m}}$. At $21^{\mathrm{h}}$ dark fiery-red band, extending from about W.N.W. to N.N.W. Sky of sickly green colour above this. At $22^{\mathrm{h}}$ this red band was still visible.

May 5.-At $7^{\mathbf{h}}$ a sudden fall of temperature was followed immediately by a shower of snow. A fall of snow was reported from Fort William about the same time.

May 6. -At $3^{\mathrm{h}}$ small quantity of cirrus was seen almost directly over hill top, apparently coming from W.N.W., but disappearing shortly after passing zenith. At $4^{\mathrm{h}}$ quantity of cirrus had increased, and formed a tolerably compact flaky mass, still directly over hill top, but being blown about in all directions for short distances without moving away much fron its place. At $5^{\text {h }}$ direction was N.E.

May 7. --Thermometers shifted at $9^{\text {h }}$.

May 10.-At $10^{\mathrm{h}}$ strong copper-coloured corona round sun.

May 11.-At $13^{\text {h }}$ halo, red inside, seen on blue sky, where no cloudiness was apparent. Horizon clear in afternoon, but no strong sunset colours seen.

May 13.-At $1^{\text {h }}$ and $2^{\text {h }}$ fog crystals forming, though 
the fog was not very thick. At $7^{\mathrm{h}}$ copper colour under $/$ seen, both arcs very perfect at times. No rain fell here sun. Very clear views in afternoon, but at $16^{\mathrm{h}}$ dark shower over upper Locheil and Banavie. Telegraph instrument affected by earth currents from $21^{\mathrm{h}}$ to $22^{\mathrm{h}}$. Apparently a continuous current in cable, varying in strength rapidly, but constant in direction. Aurora seen at $23^{\mathrm{h}}$, faint light to N.N.E., and waves of light passing across zenith. Telegraph instrument worked quite well after $22^{\mathrm{h}}$. Earth currents were felt in all the wires at Fort William office.

May 18.-Thermometer box shifted at $11^{\mathrm{h}}$. In afternoon heavy cum.-str. pallium over all the mainland, lying just higher than the hill tops; to the west, over the sea, greenish-yellow hazy light.

May 20.- Fog crystals forming freely all day, rather icy in texture.

May 22.-At $22^{\text {h }}$ fog breaking to N. At $23^{\text {h }}$ light fog passing; sky half clear; misty corona (red outside), with blue margin. At midnight sky cloudless. Double corona, inner one a greenish-yellow look inside the red; outer one very blue inside red, no yellow. No margin. Northern sky coloured orange and yellow at horizon, green and blue above all night.

May 23. - Shifted thermometer box at $0^{\text {h }} 20^{\mathrm{m}}$. All night the northern horizon was tinged with orange and green. Fog and haze in valleys till $4^{\text {h. }}$. Heavy cloudbank to E. at sunrise. At $7^{\mathbf{h}}$ copper-coloured hazy corona round sun, at the lower edge of which was a bright red spot. Up to $10^{\mathrm{h}}$ dense cumulus hanging about lower hills. Fog came on at $13^{\mathrm{h}} 5^{\mathrm{m}}$.

May 25.-At $21^{\text {h }}$ sun just set; N.W. horizon red, with yellow above it. No afterglow. At $22^{\mathrm{h}}$ and $23^{\mathrm{h}}$ double misty lunar corona formed on scud, inner one yellow inside the red, outer one blue. Fog driving past all the time, but sky clear, except for cirrus.

May 26.-Misty lunar corona observed in early morning, and again at night.

May 30.--Shifted thermometer box at $0^{\mathbf{h}} 10^{\mathrm{m}}$. Icy fog crystals forming out of mist in early morning; none at night.

June 6.-At $12^{\mathrm{h}}$ a bird, species not determined, seen on roof of office. At $14^{\mathrm{h}} 10^{\mathrm{m}}$ thermometer box shifted. No unusual colours in sky, except faint dusty-red corona round sun. No afterglow at sunset. Northern horizon orange coloured all night.

June 7.-At $1^{\mathrm{h}}$ and $2^{\mathrm{h}}$ the sky to N.N.E. above where the sun was, was covered with very thin cirrus clouds, coloured pearly grey and pale green. Dull orange at horizon. From $5^{\mathrm{h}}$ to $9^{\mathrm{h}}$ fog observed coming over the southern hills from the S.E. At $8^{\mathrm{h}}$ sun surrounded by usual dusty-red corona, but a cloud seen for a few minutes in the corona was coloured red, blue, and pink. Dense haze at horizon all day, rising above level of hill top, and cutting off sunset view. No afterglow.

June 8.-No unusual colours in sky at sunrise, sunset, nor during the day. The usual dusty-red corona at sun was almost absent. At $18^{\mathbf{b}}$ and $19^{\mathbf{b}}$ rain and hail fell, but in very small quantities; rapidly ascending columns of cloud or fog observed to E. and N.E. of summit.

June 9.- In evening loose detached fog in valleys. Dark blue haze and heavy clouds to westward at $21^{\mathrm{h}}$, with loose fog blowing past the Ben.

June 13.-At $20^{\mathrm{h}} 10^{\mathrm{m}}$ hail shower, which lasted some $15^{\mathrm{m}}$. At the same time, and till $20^{\mathrm{h}} 45^{\mathrm{m}}$, double rainbow

At $21^{\mathbf{h}}$ fog in valleys, especially to westward. Heavy pallium of cum.-str. The sky to N.W., between the fog and the clouds, orange coloured. At $22^{\mathrm{h}}$ rather gloomy to S.W., the cloud and fog mixing over Loch Linnhe.

June 14.-Air dry in early morning, but rain falling in large or moderately large drops up to $2^{\mathrm{h}}$.

June 15.-To-day Stewart came up with two horses. They were unable to get further than the second gorge. June 17.-At $0^{\mathrm{h}} 15^{\mathrm{m}}$ box shifted to admit of muslin on wet bulb being renewed. At $2^{\text {h }} 10^{\text {m }}$ box shifted again.

June 20.-Very squally at night, the top almost clear of fog between the gusts.

June 24.-Thermometer box shifted at Blue, with $10^{\mathrm{h}} 10^{\mathrm{m}}$. At $10^{\mathrm{h}}$ huge masses of cumulus small cirrus rising from valleys all round Ben. At $14^{\mathrm{h}}$ White heavy showers to westward. At $23^{\text {h }}$ horizon Thin cloud to N.N.W. coloured as in margin above Dull orange haze or cloudbank. At midnight faint Horizon brown colour in sky under moon. No distinct edge to it.

June 25. - At $8^{\text {h }}$ rosy corona round sun. At $19^{\text {h }}$ pinkish colour above sun, and dirty yellow below it. Almost no colour in northern sky at night. Very fine, with clear views all afternoon.

June 26. - At $4^{\mathrm{h}}$, the sun being very low, double ringed glories were observed on the thin fog blowing across the hill top. From the top of the tower complete circles, except where cut by the observer's shadow, were seen. Too evanescent to measure. Colours rather blurred. At $11^{\mathrm{h}}$ a cloud descended vertically just above the Ben with great velocity. It did not, however, reach the hill. At $22^{\mathrm{h}}$ hills round deep blue in colour. Sudden rise of temperature at $22^{\mathrm{h}}$.

June 27.-Thin fog on hill top in early morning, detached fog in valleys all day, and denser fog over Atlantic from Skye to Mull. Air very clear, except for this fog. In afternoon thin fog hanging about the hill sides and rising vertically from Glen Nevis. Dense cumulus palliunı above all the land, but apparently sky clear above the fog on western sea. At night clear red or orange streak under this cloud to northward. Thermometer box shifted at $11^{\mathrm{h}} 10^{\mathrm{m}}$. Mended Robinson anemometer in afternoon, soldering flexible shaft where broken.

June 28.-Up to $4^{\mathrm{h}}$ dense low-lying fog in valleys north of the head of Loch Lochy. Haze and detached cumulus fog on other hills all day, also over Atlantic.

June 30.-At $5^{\text {b }}$ ice forming on all exposed surfaces. After $21^{\mathbf{h}}$ dense level-topped fog filling all valleys. At $23^{\text {h }}$ cirrus cloud bank to N.W. gradually approaching.

July 1.-Fog in valleys same as yesterday. No unusual colours in sky all day. Beautiful pearly coloured cirrus to northward at $23^{\mathrm{h}}$ and midnight.

July 2.-Dense fog in valleys all day. At $3^{\text {h }}$ faint upper glow in sky to N.E. No unusual colours in sky during the day nor at sunset. Haze above fog to W. and N.W. all afternoon.

July 3.-At $1^{\mathrm{h}}$ and $2^{\mathrm{h}}$ small misty $\begin{aligned} & \text { Red } \\ & \text { Red }\end{aligned}$ corona observed. Colours as in margin, Greenish with a very faint blue margin outside red. yellow Radius of red ring by stephanome, $1^{\circ} 52^{\prime}$.

July 10 .- At $3^{\mathrm{h}}$ rain-gange found leaning over about $20^{\circ}$ to windward, no correction applied to readings.

Juiy 13. - Detached fog in valleys and over distant 
hills all day, that in the glens around Ben Nevis occasionally rising and enveloping the top.

July 17.-Top clear at intervals, and sky visible for a short time, overcast with stratus or cum.-str.

July 18. - At $6^{\text {h }}$ solar halo observed. Radius by stepha. Faint white nome, $22^{\circ} 49^{\prime}$. Rather indistinct.

Strong white July 19.-At $9^{\mathrm{h}}$ solar corona" coloured as Faint red in margin. Loose thin fog hanging about Pink the Ben all day, but no dense fog in D valleys, and no haze at horizon.

July 20.-Low fog in valleys to E. and N. in early morning. Frost on roof till $4^{\mathrm{h}}$. During the day and at night no fog in valleys, but rolling masses of cumulus fog about the hill sides.

July 21.-Fog both in valleys and on hills to eastward in early morning.

July 23. - Dense fog in valleys in early morning, rising and covering the hill top for a short time at sunrise. In afternoon no fog in valleys, but very thick looking fog over Atlantic. At $23^{\text {h }}$ faint brown colour under moon.

July 24. - All morning dense level-topped fog in valleys, rising to about 2000 feet. Solar halo observed at $17^{\mathrm{b}}$. Radius by stephanome (mean of six readings), $22^{\circ} 27^{\prime}$. Dry fog came on at $23^{\text {h }}$.

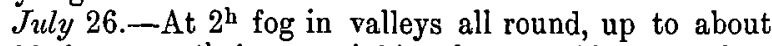
3500 feet; at $4^{\text {h }}$ it was sinking lower. Air very clear above the fog. At $8^{\mathrm{h}}$ this fog was breaking up. By $12^{\mathrm{h}}$ the valleys were clear, and the hill tops in some parts capped with cumulus fog. At $14^{\text {h }}$ the valleys to westward began to fill with fog again, and it came over the hills to the west of Loch Jinnhe, in the evening all the valleys were full again up to about 3500 feet. At midnight faint brown colour under moon.

July 27.-Thick fog in valleys till $4^{\text {h }}$, rising to about 4000 feet. At $6^{\mathrm{h}}$ and $7^{\mathrm{h}}$ broken fog or cumulus over hills, Jen clear. Loose fog hanging about the sides of Ben Nevis all afternoon.

July 28. -At $1^{\mathbf{h}}$ faint brown colour under moon. Dense fog over Moor of Rannoch all morning. At $3^{\text {h }}$ $30^{\mathrm{m}}$ violet foreglow in N.E. sky. At $4^{\mathrm{h}}$, just before sunrise, reddish glow above horizon to S.W. Violet glow to N.W. at $21^{\mathrm{h}}$. At $23^{\mathrm{h}}$ very faint brown colour under moon.

July 29.-At $3^{\text {h }}$ heavy dew on all wood outside, not on stones; this continued till $6^{\mathrm{h}}$. No upper glows before sunrise, or after sunset. Horizon very hazy in early morning, and again at night. During the afternoon several sudden and apparently rotary gusts of wind crossed the hill top ; force about 2, very local in action.

July $30 .-$ At $1^{\text {h }}$ the whole sky was dull blue above the thick haze that covered the horizon, except to the N. and N.N.E. where a distinct path of light, coloured red and pearly grey, and bounded by a sharp well-marked line, was observed. This light was probably due to the sun, and was not auroral. At $3^{\text {h }}$ very low-lying fog over Caledonian Canal valley. At $4^{\mathrm{h}}$, just before sunrise, reddish glow to $\mathrm{S}$.W. above haze. At $21^{\mathrm{h}}$ faint purple or violet afterglow observed in sky to N.W. Thick haze all round all day, quite shutting out the distant view.

July 31.-At $2^{\text {h }}$ it was observed that the dew was lying heavily on the top of the thermometer box, but not on stones, nor on either lead or wood of roof.

Aug. 1.-Before sunrise, at $4^{\text {h }}$, low fog in valleys to N. and E. Thick haze all round all day. At $20^{\mathrm{h}} 50^{\mathrm{m}}$

Mr Rankin heard several peals of thunder when standing at Maclean's steep, none heard at Observatory. Faint afterglow at $21^{\mathrm{h}}$. Heavy dew at night.

Aug. 2.-At $1^{\mathrm{h}}$ and $2^{\mathrm{h}}$ dense fog in valleys to S.E., rising to about 4000 feet. At these hours misty corona round moon. Colours rather blurred, red outside. Radius of red, $3^{\circ} 16^{\prime}$. At $4^{\text {h }}$ faint violet foreglow to N.E. At $11^{\mathrm{h}}$ glories on fog in valley to N. Radius by stephanome, $3^{\circ} 36^{\prime}$.

Aug. 4.-In early morning, all exposed surfaces, including bulbs and stems of exposed thermometers, thickly coated with ice. Robinson anemometer working stiffly from the same cause. Fog distinctly sank under hill top at night.

Aug. 5.-Faint afterglow at sunset. At midnight, northern horizon bright, but scarcely coloured.

Aug. 12.-High wind at night, northerly and very squally. Back swirls distinctly marked. Thermometer box louvres badly choked with snow all the afternoon and night.

Aug. 14.-Aurora seen for a very short time about $22^{\text {h }}$ $35^{\mathrm{m}}$. Stars very clear and bright at night.

Aug. 15.-Sky ugly at $20^{\mathrm{h}}$ and $21^{\mathrm{h}}$, and low fog over Loch Linnhe.

Aug. 17.- No unusual colours in sky in afternoon, but at sunset the clouds all over the sky were crimson and yellow.

Aug. 18.-Fog in valleys till $3^{\mathrm{h}}$, clear at $4^{\mathrm{h}}$, but level. topped cloud or fog on hills to north at $5^{\mathrm{h}}$. Very little fog in valleys all day, but at $17^{\mathrm{h}}$ cloud-fog over hills to westward, and later, fog on Atlantic. At $20^{\mathrm{h}} 20^{\mathrm{m}}$ afterglow with pinkish streamers. Very clear sky at night.

Aug. 19.-At $4^{\mathrm{h}}$ fog in valleys far to northward. Blue haze on hills round all morning, no fog in valleys after $6^{\mathrm{b}}$. Very faint afterglow at $20^{\mathrm{h}}$. Haze in valleys getting thicker at night.

Aug. 20. - At $4^{\mathrm{h}}$ the haze in valleys was mixed with detached pieces of fog. In the forenoon fog from the hills to eastward came rolling all round Ben Nevis, occasionally even brushing the top. At $20^{\mathrm{h}}$ violet or pink afterglow, well marked. At same hour the sound of the waterfall in Glen Nevis distinctly heard at Wragge's well. In afternoon faint brown colour in sky near sun, and at night below moon.

Aug. 21.-At $2^{\text {h }}$ bright light to northward, possibly auroral. Hazy all day; but no fog in valleys or on hills round till $22^{\mathrm{h}}$, when it gathered on the hills to eastward, and afterwards sank into the valleys, mixing with the haze.

Aug. 22.- - Haze and low fog in valleys all morning. Fog passing over hill top all afternoon, but about $23^{\mathrm{h}} 30^{\mathrm{m}}$ it sank below into the valleys, forming a dense billowy sheet over almost all the surrounding hills. Misty corona at $23^{\mathrm{h}}$. Colours as in margin; the blue margin being

Blue Yellow ) well marked. Radius of red by stephanome about $1^{\circ} 50^{\prime}$. Faint brown colour under moon at midnight.

Aug. 23.-Faint brown colour under moon at $1^{\text {th }}$. Dense level-topped fog or cloud over all the hills round all night, up to about 4000 feet. Faint upper glow at $4^{\text {h }}$ $30^{\mathrm{m}}$. About $14^{\mathrm{h}}$ the fog rose and covered the hill top. At 16 and $17^{\mathrm{h}}$ the fog had cleared to northward, but was still hanging above Glen Nevis to southward. Fog or cloud on hills to westward at $20^{\mathrm{h}}$. At midnight low fog 

Red
Blue-green
Red to southward. Double corona at $21^{\mathrm{h}}$.
Yellow $\quad$ Colours as in margin. Heavy dew at
nugh. 24.- - Fog, level-topped, to 4000 feet all round, till
A hours; rain and fog reported from Fort William. At
noon fog covered the hill top and lasted till $22^{\mathrm{h}}$, getting
gradually wetter. Slight drizzle at times. At $22^{\mathrm{h}}$ fog
began to sink, and top was clear about midnight. Double
lunar corona from $22^{\mathrm{h}}$ to midnight. Rather misty looking
colours, same as last night.

Red Aug. 25.-Double lunar corona observed

Blue at $1^{\mathrm{h}}$. Colours as in margin. Radius of

Red ouw outer red about $9^{\circ} 4^{\prime}$; of inner red about

Whitish $\quad 5^{\circ} 14^{\prime}$; of yellow about $3^{\circ} 36^{\prime}$. Rather D too misty looking to measure accurately.

Aug. 26.-At $23^{\mathrm{h}}$ tied Robinson anemometer up. Today water was carried up from Buchan's well.

Aug. 27.-Robinson anemometer set agoing at $13^{\mathrm{h}}$, but tied up again at $20^{\mathrm{h}}$. At $20^{\mathrm{h}}$ black bulb radiometer taken in. White fog crystals forming at night.

Aug. 28 -Robinson set agoing at $14^{\text {h }}$, but tied up again at $20^{\mathrm{h}}$. At $15^{\mathrm{h}}$ and $16^{\mathrm{h}}$ heavy cloud bank over Mill.

Aug. 29.-Very slight showers of snow in afternoon and evening.

Aug. 30.- Robinson anemometer set agoing at $13^{\mathrm{h}}$. Thick haze, mixed with fog, in valleys all round at night.

Aug. 31.-Thick haze all round in forenoon, fog on hills to $\mathrm{S}$. and $\mathrm{W}$. at times, clearer in afternoon, but thick haze again at night.

Sept. 1.-Thick haze in valleys all morning, and fog on hills round in forenoon. Faint upper glow at $5^{\mathrm{h}}$; before sunrise.

Sept. 4.-At $20^{\text {h }}$ earth currents observed on telegraph (needle) instrument. Constant in direction, keeping the needle over to right.

Sept. 7.- In the afternoon a sharp shower of rain fell, the hill top remaining clear. At $17^{\mathrm{h}} 30^{\mathrm{m}}$ a rainbow was seen over the east end of the hill; about $250^{\circ}$ of arc being visible. The colours of the primary bow were intensely bright, and inside was one strong spurious bow, and a second distinctly marked. The secondary bow was also bright. What appeared to be faint traces of an outer secondary bow were seen on the north side, but these are doubtful.

Sept. 9. -At $22^{\text {h }}$ a very heavy shorrer of hail fell, the hailstones being of considerable size. During the shower, the tips of the lightning conductor, and the point of the vane of Chrystal's anemometers, were tipped with St Elmo's fire. At $22^{\mathrm{h}} 15^{\mathrm{m}}$ the shower was over, and the fire had disappeared.

Sept. 17.-Hill top clear. After $10^{\mathrm{h}}$ thick fog all round, and sky covered with cum.-str., which cleared off gradually in afternoon. Fog sank after $18^{\mathrm{h}}$. Sky pale yellow to westwards at sunset, with rosy afterglow high up. Greenish blue colour to southwards, and faint lunar corona formed by very thin almost invisible scud. At $22^{\mathrm{b}}$ $7^{\mathrm{m}}$ a meteor was observed to eastwards, described about $10^{\circ}$ of arc. Not very bright.

Sept. 24.- Snow fell nearly all day, drifting slightly. Exposed (radiation) thermometers could not be read or set. Snow about 4 inches deep at night.

Sept. 25.-Showers of snow occasionally, about 6 inches

TRANS. ROY. SOC. EDIN. VOL. XXXIV. deep at night. Exposed thermometers still immovable. Top clear in afternoon, and after $22^{\mathrm{h}}$. Ross-shire hills seen coated down to about 2500 feet level.

Sept. 26.-Readings of rain-gauge doubtful all day, as snow was drifting considerably.

Sept. 27. - Sun rose above a heavy bank of stratus at $6^{\mathrm{h}} 15^{\mathrm{m}}$. At $5^{\mathrm{h}} 40^{\mathrm{m}}$ rosy coloured streamers were seen. These disappeared at $5^{\mathrm{h}} 50^{\mathrm{m}}$ leaving rosy glow all over eastern sky. At $6^{\mathrm{h}} 5^{\mathrm{m}}$ rosy colour disappeared from eastern sky, and was seen to westwards, lower edge being sharply defined by dark earth-shadow.

Sept. 30.-Very stormy after $4^{\text {h }}$. Barometer pumping heavily, and mercury surfaces much disturbed owing to shaking of the house.

Oct. 1.-At $5^{\text {h }}$ St Elmo's fire seen on tips of lightning conductor, and on Chrystal and Robinson anemometers. It was accompanied by a sound similar to that of an electrical machine, which continued after $5^{\mathrm{h}} 3^{\mathrm{m}}$, when fire ceased. This sound was again heard on lightning conductor, \&c., and also on top of snow post (A), at $14^{\mathrm{h}}$.

Oct. 4. - At $12^{\text {h }}$ the rain-gauge was found almost buried in drift. At $15^{\text {h }}$ it was found with the snow cut away from under it by the wind, and lying over about $20^{\circ}$ to windward. All the measurements are vitiated by drift.

Oct. 6. - New small thermometer box put on ladderstand at $15^{\mathrm{h}} 20^{\mathrm{m}}$. The dry and wet in large box were so hard frozen that they could not be got in.

Oct. 11.-Thermometer box shifted at $13^{\mathrm{h}} 10^{\mathrm{m}}$.

Oct. 12. - At $5^{\mathrm{h}}$ glow in sky to eastward about $15^{\circ}$ high. At $9^{\mathrm{h}}$ needle-shaped crystals of snow falling.

Oct. 15. - Thermometer box shifted at $13^{\mathrm{h}} 10^{\mathrm{m}}$. Top clear in afternoon, no fog in valleys. The increase in depth of snow as measured at gauge (31" at $10^{11}$ and $33^{\prime \prime}$ at $22^{\mathrm{h}}$ ) is due to the fog crystals on the post falling off with the thaw.

Oct. 16.-At $2^{\mathrm{h}}$ and $3^{\mathrm{h}}$ faint white glare at northern horizon, possibly auroral. At $6^{\mathrm{h}}$ bright sunrise colours ; fog on bills and haze in valleys. The haze remained all day in the valleys, but the fog cleared off the hills as the day went on, except to S.W., it looked dark and gloomy all day over Mull. Blood-red streak at W. and N.W. horizon at sunset.

Oct. 17.-At $9^{\text {h }}$ faint white solar holo, no colours seen. At same hour thin flat sheets of cloud observed forming and vanishing over adjacent hills, and on west end of top of Ben Nevis.

Oct. 18.- In afternoon level-topped fog all round, rising to about 4000 feet. Sky very blue and clear, with no unusual colours. Afterglow broken by curious gaps observed at $18^{\mathrm{h}}$

Oct. 19.-At $6^{\text {h }}$ eastern horizon red below and intensely green above, faint pink glow at about $20^{\circ}$ altitude. At $8^{\mathbf{h}}$ the fog had risen to the level of the hill top, threeringed glory seen. At $10^{\mathrm{h}}$ no trace of rain-band visible from zenith to horizon. Dry white fog crystals forming all afternoon and evening.

Oct. 20.-At $7^{\mathrm{h}}$ fog on hills to 3000 feet. At $10^{\mathrm{h}}$ broken fog rising from valleys everywhere. During the afternoon and evening fog all round, coming over the top of Ben Nevis at intervals. At $22^{\mathrm{h}}$ double Red lunar corona, with faint traces of outer blue Green margin, formed on this fog. Colours as in Red margin. Radius of inner red, $1^{\circ} 45^{\prime}$; outer Yellowish white red, $3^{\circ} 52^{\prime}$.

D 
Oct. 21.-At $1^{\text {lh }}$ fog in valleys, thickest to eastward. No fog in valleys all day, but cumulus fog on distant hills in morning, which lifted and cleared away about noon. Very little colour in the eastern sky at sunrise. Thermometer box shifted at $14^{\mathrm{h}} 15^{\mathrm{m}}$.

Oct. 22.-At $3^{\text {h }}$ very faint brown colour Red Preen and Blue rise faint. No fog in valleys all day. Yellowish-red Double corona observed at $19^{\mathrm{h}}$. Colours White as in margin. Radius-Outer red, $10^{\circ} 5.3^{\prime}$; green and blue, $6^{\circ} 55^{\prime}$; purple, $4^{\circ} 40^{\prime}$; inner red, $3^{\circ} 42^{\prime}$; white, $2^{\circ} 25^{\prime}$. Similar corona seen at Red midnight. Colours as in margin. The Yellow Green Red Yellowishwhite white Oct. 23.-Double corona at $2^{\mathrm{h}}$, with at times faint third ring. Colours as in margin. No blue or green inside the Red inner red. Yellow, both outer and inner, Yellow only a thin strip; reds and green broader, Green and not so sharp. Radius of inner red, $2^{\circ}$ Red $29^{\prime}$; outer red, $4^{\circ} 43^{\prime}$; inner yellow, $2^{\circ} 4^{\prime}$; Yellow-whitish outer yellow, $4^{\circ} 8^{\prime}$. I Iunar halo (colourless) D seen at $3^{\text {h }}$. Radius to inside of halo, $21^{\circ} 48^{\prime}$ by stephanome; outside of halo, $25^{\circ} 13^{\prime}$. The halo was somewhat indistinct, and the measurements are rather rough. It was again seen at $4^{\mathrm{h}}$. At $3^{\mathrm{h}}$ the cirrus

Red

Yellow

Bluish-green

Red

Bluish-white D)

size varied according to the sort of cloud or fog it was formed on. The following measurements were taken within $3^{\mathrm{m}}$ of each other. First, radius of inner red, $2^{\circ} 14^{\prime}$; outer red, $4^{\circ} 18^{\prime}$. Second, radius of inner red, $2^{\circ} 50^{\prime}$; outer red, $4^{\circ} 49^{\prime}$.

Oct. 24 . - At $2^{\text {h }}$ sky cloudless, and a faint white glow all round horizon. No fog in valleys, except over Loch Lochy, in early morning, but loose fog on hills round in afternoon. Yellow, green, and blue colours in western sky after sunset, and faint brown colour under moon at night.

Oct. 25.-At $2^{\mathrm{h}}$ sky cloudless, except for a patch of cumulus over Loch Linnhe, below Ardgour, apparently at

Red

Yellow

Green

Red

Yellow

Watery-white

D 4000 or 5000 feet elevation, and approaching Ben Nevis. Fog blowing across top at $3^{\text {h }}$. At $4^{\text {h }}$ double corona, with traces of third ring. As before, the yellows were narrow, and the green broad. Colours as in margin. Radius of inner red, $2^{\circ} 10^{\prime}$; outer red, $4^{\circ} 20^{\prime}$; inner yellow, $1^{\circ} 45^{\prime}$; outer yellow, $3^{\circ} 50^{\prime}$. White feathery fog crystals forming in forenoon.

Oct, 27.-Thermometer box shifted at $0^{\mathbf{h}} 20^{\mathrm{m}}$. St Elmo's fire observed on lightning conductor at $19^{\mathrm{h}}$. No sounds heard.

Oct. 28. - Thermometer box shifted at $0^{\mathrm{h}} 20^{\mathrm{m}}$.

Oct, 29.-Rain-gauge measurements in early morning quite untrustworthy through drift. Thermometer box shifted at $9^{\mathrm{h}} 10^{\mathrm{m}}$. At $14^{\mathrm{h}}$ brown colour in sky under sun. At $17^{\mathrm{h}}$ sky very watery to westward. At $19^{\mathrm{h}}$ faint glow to north ward, apparently auroral. At $23^{\mathrm{h}}$ cir.-str. to eastward, on which dim lunar halo was observed.

Oct. 30.-.Top clear at times in early morning, showing very ugly sky above. Very great drift during the day, the whole surface of the hill top being cut up into great trenches wherever the skin of the last fall of snow got broken. At $15^{\mathrm{h}}$ rain-gauge was taken in, and not put out again till $22^{\mathrm{h}}$, as it was only getting filled with drift, and was in danger of being blown away. No snow fell, apparently, till after $20^{\mathrm{h}}$.

Nov. 1.-Thermometer box shifted at $12^{\mathrm{h}} 10^{\mathrm{m}}$. At $23^{\mathrm{h}}$ $10^{\mathrm{m}}$ set Robinson going.

Nov. 3.-At $20^{\mathrm{h}} 10^{\mathrm{m}}$ tied up Robinson.

Nov. 5.-Thermometer box shifted at $2^{\mathrm{h}} 15^{\mathrm{m}}$.

Nov. 6.-Started Robinson anemometer at $22^{\mathrm{L}}$.

Nov. 8.- Robinson anemometer tied up at $19^{\mathrm{h}}$. Fog crystals forming freely at night.

Nov. 9. - At $7^{\text {h }}$ fog very thick, but of a faint red colour. Fog cleared suddenly at $13^{\mathrm{h}} 10^{\mathrm{m}}$ sinking below Ben Nevis, but still covering all the other hills. It continued blowing across the top at times all afternoon, but was quite below Ben Nevis at night. Faint white light, possibly auroral, to N. and N.N.W. at horizon all night.

Nov. 10.-At $7^{\text {b }}$ bright yellow and orange colours at eastern horizon, and faint glow on cirri clouds above. log covering the hills to 3000 or 4000 feet all day; quite level topped. No unusual colours in sky. Started Robinson anemometer at $14^{\mathrm{h}} 5^{\mathrm{m}}$. Aurora at night. It got gradually fainter as the night went on; no streamers were observed except one at $21^{\mathrm{h}}$.

Nov. 11.-At $6^{\text {h }}$ deep scarlet colour at eastern horizon. At $7^{\mathrm{h}}$ broad orange band fringed with faint purple above to eastward. Also very faint upper glow. From sights taken during the night it was determined the aurora of last night extended from $2^{\circ}$ above horizon to from $10^{\circ}$ to $15^{\circ}$. At $9^{\text {h }}$ glory with one ring observed. Radius to outside of the red, $2^{\circ} 21^{\prime}$; inside, $1^{\circ} 44^{\prime}$. At $15^{\text {h }}$ glory with 3 reds observed. The inner a mere blotch, the next well-marked ring with most of the colours; outermost the same, but much fainter. Radius of $\operatorname{red}^{1}=3^{\circ} 46^{\prime}$; $\operatorname{red}^{2}$ $=1^{\circ} 52^{\prime}-$ (red outside in both rings). At $16^{\mathrm{b}} 30^{\mathrm{m}}$ pink band above E. and N.E. horizon; no sunset colours except faint afterglow. Aurora with streamers at night. At $22^{\mathrm{h}}$ the fog, which had stood at about 4000 feet all day, rose suddenly higher than, and enveloped, the top. The temperature fell at once, and the wind lulled gradually. After the midnight observation the Robinson anemometer was tied up.

Nov. 13.--Very icy fog crystals on exposed surfaces. Thermometer box shifted at $22^{\mathrm{h}} 20^{\mathrm{m}}$.

Nov. 14.-New 5-inch rain-gauges with slightly rounded bottoms came up to-day. One was put out at $15^{h}$ instead of the old pattern with stop-cock.

Nov. 15.- Haze and detached cumulus at horizon all morning. At $8^{h}$ reddish look all round horizon above the haze. No fog in valleys. Red or brown colour under sun all day. At $14^{\mathrm{h}}$ whitish-green colour all round horizon. At $15^{\text {h }}$ cloud or fog-bank on Atlantic beyond Mull. At $19^{\mathrm{b}}$ faint corona observed. Colours hardly distinguishable. Outside radius, $3^{\circ} 46^{\prime}$. At $22^{\mathrm{h}}$ low fog bank to S.W. and faint brown colour under moon.

Nov. 16.-At $9^{\mathrm{h}}$ large glory on passing fog; colours as in fig. 6 ; the inner red being close to the shadow of the observer's head. Radius of $\operatorname{red}^{2}, 7^{\circ} 38^{\prime}$. Third red 
too faint to measure. During the day whitish glare all round horizon above the haze that filled the valleys; this turned brown at sunset, but was white again at night. Faint brown colour under moon again to-night.

Nov. 17. - Thick haze in valleys all day, but thinning a little at night. At $7^{\text {h }}$ bright red. Yellow and green colours at eastern horizon. Brown colour under sun all day, and more faintly under moon at night. At $16^{\mathrm{h}}$, just before sunset, red look all round horizon. At $16^{\text {h }} 35^{\mathrm{m}}$ red, orange, and yellow at western horizon, and pink upper glow reaching to about $30^{\circ}$ altitude. At $17^{\mathrm{h}}$ fog on Mull, and at night fog all up Loch Linnhe. At midnight white belt round horizon from W.N.W. to N.N.E., and more faintly as far as $\mathrm{E}$. About $3^{\circ} \mathrm{high}$, apparently very thin cirro-stratus.

Nov. 18.-At $1^{\text {h }}$ fog low down on Loch Linnhe and Locheil, and haze in valleys to northward. At $3^{\text {h }}$ fog on Loch Lochy. Fog on Locheil continued till $10^{\mathrm{h}}$. At sunrise fog on Moor of Rannoch, and haze over Atlantic and Moray Firth. Brown colour under sun all afternoon. At $19^{\mathrm{h}}, 20^{\mathrm{h}}$, and $21^{\mathrm{h}}$ aurora seen ;-several arches, the lowest being composed of vertical wavy streamers, the higher ones of simple streaks of light. Height to bottom of first arch, $6^{\circ} 12^{\prime}$; top, $17^{\circ} 30^{\prime}$. Green band in spectroscope very distinct. Shortly before $22^{\mathrm{h}}$ thin fog began to blow over the top of Ben Nevis. At $23^{\mathrm{h}}$ double lunar corona, red outside. The size varied very much; at times the two sets of colours merged into one misty corona, a second forming gradually outside as these shrank into one.

Nov. 19.-Lunar fog-bow (no colours), seen in early morning. Loose feathery white fog crystals forming freely all afternoon and night.

Nov. 20.-Dense fog blowing in waves over the hill top till $18^{\text {h }}$, very thick, but not reaching high up. Dark roll-cum, at horizon at night. Thermometer box shifted at $22^{\mathrm{h}} 15^{\mathrm{m}}$.

Nov. 21.-Detached patches of fog on hills to southward all morning. The surface of the snow on the hill top was found to-day to be all roughened by the for crystals on it. They were 2 to 6 inches in length, and quite dry.

Nov. 22.-At $8^{\text {h }}$ it was observed that the fields near the sea-level were white with hoar frost. Sun much enlarged and elongated when rising; the vertical and horizontal diameters appearing as 3 to 5 . At $14^{\text {h }}$ brown colour under sun. Haze and fog on Locheil and in Caledonian Valley, risins higher at night and getting thicker to north ward. Earth shadow observed at sunset. Sunset colours weak, and little or no afterglow. At $18^{\mathrm{h}}$ brown colour under moon. Sky covered more or less with cirro-cumulus till midnight. On this a faint, badlydefined lunar corona was observed at $19^{\mathrm{h}}$ and $20^{\mathrm{h}}$. At Pale red $20^{\mathrm{h}}$, colours somewhat as in margin, but $\begin{array}{ll}\text { Yellow } & \text { very badly defined. At } 19^{\mathrm{h}} \text { only one red- } \\ \text { Bluish-white dish ring. Radius to inside, } 1^{\circ} 54^{\prime} \text {; out- }\end{array}$ D side, $4^{\circ} 18^{\prime}$. At $20^{\mathrm{h}}$, radius of red, $2^{\circ} 54^{\prime}$; yellow, $2^{\circ} 35^{\prime}$; outside of blue, $1^{\circ} 42^{\prime}$. Blue much broader than the red or yellow, and with no defined inner margin. Nov. 23.-Double corona on cir.-cum. at $4^{\mathrm{h}}$. Badly Red

Green

Yellow

Bluish defined, but of normal form. Radius of outer red, $6^{\circ} 48^{\prime}$; inner red, $3^{\circ} 7^{\prime}$; yellow, $2^{\circ} 42^{\prime}$. Yellow, a narrow line; green, a broad belt. White fog crystals forming freely all day.
Nov. 26. - At $9^{\text {h }}$, as it was blowing very hard, one of the old rain-gauges of heavier make was put out. The gauge was taken in at $14^{\mathrm{h}}$, and not put out again to-day, as it was impossible to manage it in the strong wind. At $17^{\text {th }}$ began to use lantern fitted inside an oilskin coat. At $22^{\mathrm{h}}$ note-book blown away when re-entering tower door. At $14^{\mathrm{h}}$ it was observed that the upper part of the snowpost $A$ had been blown away.

Nov. 27.-Thermometer box shifted at $22^{\mathrm{h}} 20^{\mathrm{m}}$.

Nov. 30.-At $6^{\text {h }}$ St Elmo's fire observed on lightning conductor, both anemometers, and on top of ladder leading up tower outside. No sounds heard, even when quite close to the conductor.

Dec. 1.-Heavy showers of snow, sleet, and hail all day. Lourres of thermometer box badly choked.

Dec. 2.-At $13^{\text {h }}$ the rain-gauge was taken in, as it was getting choked with drift. It was put out again at $15^{\mathrm{h}}$. Thermometer box shifted at $17^{\mathrm{h}} 15^{\mathrm{m}}$.

Dec. 3.-At $20^{\mathrm{h}}$ the rain-gauge was found leaning over to windward, having been under-cut by the wind, and full of drift.

Dec. 5.-Thermometer box shifted at $2^{\mathrm{h}} 25^{\mathrm{m}}$.

Dec. 6. - At $8^{\text {h }}$ bright pink upper glow to E., horizon yellow; no red colour visible. Snow down to about 600 feet. Sunset colours at $16^{\text {h }}$ weak. No afterglow. Wellmarked auroral arch all night; no streamers. Height of top of arch above horizon at $19^{\mathrm{h}}, 12^{\circ}$. The dry-bulb readings at $15^{\mathrm{h}}$ and $17^{\mathrm{b}}$ being below $10^{\circ}$ - the limit of Glaisher's Tables-the factor was assumed to be 8.8 , and the dew points calculated by that.

Dec. 7.-Faint aurora similar to last night, visible from $19^{\mathrm{h}}$ to midnight.

Dec. 9.-Thermometer box shifted at $15^{\mathrm{h}} 20^{\mathrm{m}}$.

Dec. 10.-At $0^{\mathrm{h}} 8^{\mathrm{m}}$ thermometers shifted.

Dec. 12.-Thermometer box shifted at $15^{\mathrm{h}} 20^{\mathrm{m}}$.

Dec. 14. - Started Robinson at $16^{\mathrm{h}} 20^{\mathrm{m}}$, but tied it $\mathrm{u}_{\mathrm{p}}$ again just after midnight.

Dec. 15.-At $12^{\mathrm{h}}$ faint brown colour under sun. Dense rolling fog on hill top all round. At $17^{\mathrm{h}}$ moon shining faintly through cir.-str. clouds, but no halo visible.

Dec. 16. - Double corona at $20^{\mathrm{h}}$; colours as in margin ; Outer yellow very faint. Formed on scud; no corona when scud clears off. Radius of outer red, $3^{\circ} 48^{\prime}$; inner red, $1^{\circ} 58^{\prime}$; outer yellow, $3^{\circ} 38^{\prime}$; inner yellow, less than $1^{\circ} 40^{\prime}$. Very faint traces of third ring at times. Similar corona at $22^{\text {h }}$. When the scud got very thick, the outer part was more yellow, and less blue-looking. Radius of outer red, $3^{\circ} 33^{\prime}$; inner red, $1^{\circ} 53^{\prime}$; outer yellow, $3^{\circ} 0^{\prime}$; inner yellow, $1^{\circ} 23^{\prime} . \quad 2^{\mathrm{m}}$ afterwards, outer red, $3^{\circ} 8^{\prime}$; inner red, $1^{\circ} 42^{\prime}$. At midnight lunar fog-bow ; no colours.

Dec. 17. - Faint afterglow at $16^{\mathrm{h}}$. At $17^{\mathrm{h}}$ western horizon still coloured red, yellow, and green. Fog on hills to 3000 or 4000 feet all afternoon and night. Double lunar corona at $20^{h}$, formed on very thin mist or scud blowing over the hill, flashing into sight and disappearing again; outer ring blue, and inner yellow both reds well marked. Too fleeting to measure. Very faint lunar halo at $22^{\mathrm{h}}$.

Dec. 18.-At $7^{\text {h }}$ deep, soft, blood-red and scarlet colours at horizon to E.S.E. At $8^{\mathrm{h}} 20^{\mathrm{m}}$ upper glow to S.E. and S.S.E., the northern side having well marked long streamers. Sun rose $8^{\mathrm{h}} 45^{\mathrm{m}}$. At $8^{\mathrm{h}} 40^{\mathrm{m}}$ the upper 
glow was gone, but there was a white glare in the sky above a brick-red streak at horizon. Sun rose egg-shaped, long axis horizontal, and took $4^{\text {in }} 20^{\text {s }}$ to rise. At $9^{\mathrm{h}}$ the shadow of Ben Nevis was seen on pink-coloured haze above the horizon to N.W. At $10^{\text {h }}$ brown colour under sun, and misty looking glare round it. At $11^{\mathrm{h}}$ faint solar halo, white. One bright spot horizontally to eastward of sun. Brown colour under sun, and faint pinkish hue above sun inside the halo. Radius of halo by stephanome $23^{\circ} 3^{\prime}$. Brown colour under sun all afternoon. Halo faintly seen till $13^{\mathrm{h}}$. At $16^{\mathrm{h}}$ faint glow all round horizon from about $5^{\circ}$ to $15^{\circ}$. Eastern horizon dirty green under this. At $16^{\mathrm{h}} 20^{\mathrm{m}}$ distinct upper glow ; it had the appearance of a cloud of very loose texture lit up from below. Trace of this upper glow at $17^{\mathrm{h}}$, and red and yellow sunset colours. Sun set about $15^{\text {h }} 50^{\mathrm{m}}$. No unusual colours in sky at night.

Dec. 19.--Dense fog above Loch Linnhe and in Caledonian Valley to about 4000 feet in early morning. At $3^{\text {h }}$ faint blue corona $3^{\circ} 4^{\prime}$, radius round moon. The edge of the corona was the brightest part; but the whole space was blue, and no other colour was visible. At $4^{\mathrm{h}}$ similar corona, $3^{\circ} 20^{\prime}$ radius, but with very faint red edge to it outside. At same hour brown colour in sky under moon. $\Lambda \mathrm{t} 8^{\mathrm{h}}$ faint upper glow. At $8^{\mathrm{h}} 16^{\mathrm{m}}$ this glow formed a pyramid, height about $20^{\circ}$, base $45^{\circ}$, the base line being $6^{\circ}$ above horizon. At $8^{\mathrm{h}} 25^{\mathrm{m}}$ this glow was almost gone. At $8^{\text {h }} 40^{\mathrm{m}}$ a white glare had taken its place. At $9^{\mathrm{h}}$ dense haze and fog in valleys, with the shadow of Ben Nevis distinctly seen on it. At $10^{\text {h }}$ and during the rest of the day, brown colour under sun. Sunset colours weak, and afterglow very faint. The haze and fog rose higher at night and gradually covered the hill top.

Note.-The sun when rising was much elongated horizontally; it took 6 minutes to rise. At $17^{\mathrm{h}}$ lunar corona, red outside. Radius to outside of red, $4^{\circ} 13^{\prime}$; inside of blue, $2^{\circ} 55^{\prime}$. After midnight Robinson anemometer was tied up.

Dec. 20.- In early morning fog crystals were brown in colour and loose in texture. During the forenoon these were overlaid by white ones considerably harder and Red more icy. The former ones came with $\mathrm{S}$. Yellow wind and fog, the latter with S.S.W. or Blue S.W. and mist. Double corona at midRed

night; colours as in margin, but ver pale and faint. Radius of inner red, $3^{\circ} 3^{\prime}$. Fog to 4000 feet all round. Thermometer box shifted at $23^{\mathrm{h}} 15^{\mathrm{m}}$

Dec. 21. - At $5^{\text {h }}$ triple lunar corona, reds outside. Radius of inner red, $1^{\circ} 5^{\prime}$; middle red, $1^{\circ} 55^{\prime}$; outer red, $2^{\circ} 55^{\prime}$. Also lunar fog-bow. Very soft snow falling all afternoon.

Dec. 22.-Thermometer box shifted at $15^{\mathrm{h}} 15^{\mathrm{m}}$. Lunar Red balo, white, at $23^{\mathrm{h}}$. Radius to inside, Yellow $20^{\circ} 41^{\prime}$ and $20^{\circ} 16^{\prime}$; outside, $27^{\circ} 29^{\prime}$ and

Blue $27^{\circ} 23^{\prime}$. Two measurements.

Red

Pellow

Red

Yellow

Bluish-yellow

8
Dec. 24.-Robinson anemometer was started at $15^{\text {h }}$, but was tied up again after midnight. Fog (or mist) in valleys to at least 4000 feet all evening.

Dec. 25.-All exposed surfaces and the louvres of the thermometer box heavily covered with solid ice all day.

Dec. 26. -Thermometer box shifted at $8^{\mathrm{h}} 10^{\mathrm{m}}$. Ice forming on exposed surfaces at night, but not so freely as yesterday. Drizzling rain fell in the evening, though the sky was clear, and the mist hardly rose higher than the hill top.

Dec. 27.- Tce on everything, and louvres of thermometer box badly choked; ladder outside tower impassable. Thermometer box shifted at $22^{\mathrm{h}} 30^{\mathrm{m}}$.

Dec. 28.--Thermometer box shifted at $10^{\mathrm{h}} 30^{\mathrm{m}}$.

Dec. 29.-Thermometer box shifted at $17^{\mathrm{h}} 15^{\mathrm{m}}$. Very squally at night.

Dec. 31.-Robinson anemometer started at $22^{\mathrm{h}} 10^{\mathrm{mu}}$.

Notes of Irstruments In USE DURING 1885.

Fortin Barometer 1385, Negretti and Zambra.

Dry and Wet Bulbs 192,660 and 192,672, Adie and Wedderburn; also 192,677, Adie and Wedderburn, and 50,852 , Negretti and Zambra; and occasionally 50,945, 50,851 or 50,850 , Negretti and Zambra.

Maximum Thermometer 117,293 , Adie and Wedderburn, from July 25 to Oct. 6 .

Mininum Thermometer 138,533 or 138,545 , Adie and Wedderburn, Jan. 1 to July 24 , and Oct. 7 to Dec. 31 ; 116,918, Adie and Wedderburn, July 25 to Oct. 6.

Small size of louvred Thermometer Box on ladder stand, Jan. 1 to July 24, and Oct. 7 to Dec. 31 . Large louvred box (old clock box), July 25 to Oct. 6 .

Solar Radiation Thermometer (black bulb in vacuo) 186, Hicks.

Radiation Minimum (T-hollow cylindrical bulb) 46,309, Hicks.

Sunshine Recorder, Casella (made specially).

Ozone test papers surplied by Casella.

Anemometers, Robinson (velocity) and Chrystal (direction) by Frazer, Edinburgh.

Rain Gauges. Jan. 1-Jan. 8, gauges with side screw plug. Till Jan. 14, various. Jan. 15-Nov. 14, gauges with rounded bottoms and stopcock. Nov. 14-Dec. 31, gauge with slightly rounded bottoms and screw plug.

The rain gauge measurements were interrupted several times by drift.

From Feb. $21,8^{\mathrm{h}}$, to Feb. $22,7^{\mathrm{h}}$, no temperature observations could be taken.

With the above exceptions, barometer, dry bulb, wet bulb, rain, wind, cloud and sunshine records are continuous.

The Radiation Thermometers could only be used in moderately fine weather. The anemometers were often frozen up, or out of repair.

The ozone tests were read twice daily for twelve hours each, but the usual saturated condition of the atmosphere made their indications very unreliable. The papers were occasionally blown away in strong gales, and the observation thus lost. 


\section{6.}

Jan. 1.-Robinson anemometer tied up at $23^{\mathrm{h}} 10^{\mathrm{m}}$.

Jan. 3.-Robinson anemometer started at $13^{\mathrm{h}} 10^{\mathrm{m}}$, but tied up again at $14^{\mathrm{h}} 5^{\mathrm{m}}$.

Jan. 4.-Thermometer box shifted at $12^{\mathrm{h}} 10^{\mathrm{m}}$.

Jan. 5.-At $6^{\text {b }}$ tips of lightning rod, vane, and cups of anemometers and kitchen chimney glowing with St Elmo's fire; heavy hail falling at the time.

Jan. 6. - Haze at horizon and in valleys all day. At $11^{\mathrm{h}}$ great white glare round sun, and brown colour under it. This brown colour was under the sun all day. At $16^{\mathrm{h}}$ pink glow to E. No afterglow to westward till $16^{\mathrm{h}}$ $10^{\mathrm{m}}$. Earth shadow observed at $16^{\mathrm{h}} 10^{\mathrm{m}}$.

Jan. 9.-At $10^{\mathrm{h}}$ columns of fog rising out of Glen Nevis. A white ray or beam from sun observed passing vertically down over Glen Nevis. It was not caused by the sun shining through a rift in the clouds; and it was seen passing over or into Glen Nevis between the observer and the opposite hills. No corresponding ray observed above sun. At $10^{\mathrm{h}} 10^{\mathrm{m}}$ pink colour on clouds to northward close over Ben Nevis. At $12^{\mathrm{h}} 10^{\mathrm{m}}$ thermometer box shifted.

Jan 11 - Thermometer box shifted at $12^{\mathrm{h}} 10^{\mathrm{m}}$.

Jan. 13.-Thermometer box shifted at $12^{\mathrm{h}} 30^{\mathrm{m}}$.

Jan. 14. - Thermometer box shifted at $7^{\mathrm{h}} 10^{\mathrm{m}}$. After $9^{\mathrm{h}}$ the following additional observations were made :- $9^{\mathrm{h}}$ $11^{\mathrm{m}}$, dry 22.0 ; wet 25.0 -fog crossing bill at second gorge; $9^{\mathrm{h}} 17^{\mathrm{m}}$, dry 206 ; wet 21.0 -fog passing at Observatory. At $8^{\text {h }}$ under surface of pallium of a dark brown red colour.

Jan. 15.-Wind very unsteady, with back swirls all day. Louvres of thermometer box badly choked.

Jan. 16. - Thermometer box shifted at $3^{\mathrm{h}} 20^{\mathrm{m}}$.

Jan. 18.-Brown colour under moon at $5^{\mathrm{h}}$, and similar Red

Yellow

Yellowish colour under sun during day. At $17^{\text {}}$ double lunar corona; colours as in margin. Radius of red, $1^{\circ} 41^{\prime}$; yellow, $0^{\circ} 58^{\prime}$. Similar corona seen at $21^{\mathrm{h}}$.

Jan. 19.-Brown colour under moon in early morning. No usual pink foreglow at sunrise; but the under surfaces of cirrus clouds were coloured vermilion-red about 10 minutes before sunrise. Dark blue band across sky from N.E. to W. At $9^{\text {h }}$ double solar corona, consisting of two pinkish red rings; radius of inner ring about $2^{\circ} 8^{\prime}$. At $14^{\mathrm{h}}$ gauge found buried in drift up to the rim. The drift has blown away round the stand for the thermometer box, so that although the bulbs are only about 20 inches above the general surface, they are 40 or 45 inches above the surface immediately under them. This hole is about 2 yards diameter, and has steep sides.

Jan. 20.-Double lunar corona observed at $2^{\text {n }}$. Formed

Red

Yellow

Blue-green

Red on scud; colours as in margin. Very fleet-

Orange

Yellow

Whitish ing, and size varying. Two measurements within one minute gave for radius of inner red, $3^{\circ} 33^{\prime}$ and $3^{\circ} 7^{\prime}$. The colours were always the same, though the size varied. Thermometer box shifted at $3^{\mathrm{h}} 20^{\mathrm{m}}$. Brown colour under moon all morning. Same brown colour under sun in afternoon. At $17^{\mathrm{h}}$ dark red and dirty yellow at S.W., W., and N.W. horizon; under surfaces of cumulus to westward red, and under surfaces of cirrus pinkish.

TRANS. ROY. SOC. EDIN. VOL. XXXIV.
Jan. 22.-A light was observed in the north at $17^{\mathrm{h}}$ which might be auroral. Thermometer box shifted at $22^{\mathrm{h}}$ $15^{\mathrm{n}}$.

Jan. 23.-At $17^{\text {h }}$ brownish-pink colour in sky to westward above low-lying clouds. Sky green to S.S.W. Fog on hills to E. and S.

Jan. 25.-In morning fog crystals smoky brown in colour. Fog passing in waves in afternoon and at night. Very squally at night, with intervals of almost perfect calm.

Jan. 27.-Fog crystals on exposed surfaces brown. In the afternoon the fog, though very thick, was dazzling to the eyes.

Jan. 28.-Fog crystals of their usual white colour in morning, but possibly slightly brown in afternoon.

Jan. 29.- Fog crystals brown in morning. Louvres of box badly choked with snow all day.

Jan. 30.-Oue flash of lightning seen at $7^{\mathrm{h}}$. Some hail in rain-gauge at $8^{\mathrm{h}} . \quad$ At $12^{\mathrm{h}}, 13^{\mathrm{h}}$, and $14^{\mathrm{h}}$ gauge full of drift.

$F e b, 1$. - At $1^{\text {h }}$ rain-gauge found leaning over to windward, and full of drift. At $2^{\mathrm{b}}$ gauge buried almost to the rim, and full of drift. At $21^{\mathrm{h}}$ the gauge was again found almost buried. None was put out again till midnight, when it was put out as usual. Thermometer box shifted at $9^{\mathrm{b}}$ $10^{\mathrm{m}}$. At $9^{\mathrm{h}}$ fog on hills round in patches. At $11^{\mathrm{h}}$ fog joining with upper clouds over Glencoe and Loch Linnhe; very ngly. At $13^{\text {h }}$ white glare, with pink or brown edges. Between $14^{\mathrm{h}}$ and $15^{\mathrm{h}}$ brown colour under sun, and haze and cum. to S.W.

Feb. 2.-Thermometer box shifted at $23^{\mathrm{h}} 25^{\mathrm{m}}$.

Feb. 3.-No fog in valleys, but horizon bazy, especially to S.W. all day. At $8^{\mathrm{h}}$ yellowish, watery glare in sky to south-eastward $20^{\circ}$ to $30^{\circ}$ high. Pale glare, with brownish red edges round sun all day. At $17^{\mathrm{h}}$ red streak along western horizon, and above it triangle of yellowish green in sky about $60^{\circ}$ wide at base and $30^{\circ}$ high. At $19^{\mathrm{h}}$ long bluish-white glimmer in sky to westward leaning at an angle of $45^{\circ}$ to southward. Haze or fog seemed to rise up on to the hill top at night, the stars remaining bright as long as they were visible. Snow down to sea-level.

Feb. 4.-Low fog on Locheil and Loch Rannoch at $8^{\text {h }}$, which gradually passed away during the day. Brown colour under sun at $11^{\mathrm{h}}$ and all the rest of the day; pale brownish glare round sun in afternoon. Haze over Firth of Lorne all afternoon. After sunset red light all round horizon, which gradually rose to eastward, leaving an earthshadow underneath. At $19^{\mathrm{h}}$ and $20^{\mathrm{h}}$ faint triangular white glimmer in western sky similar to last night. Faint aurora seen at night.

$F e b .5$.-At $8^{\mathrm{h}}$, just before and just after sunrise, under surface of clouds blood-red. Haze thickening in valleys to $S$. and W. all morning. The clond layer seemed to come gradually down on to Ben Nevis in afternoon.

Feb. 6. - Fog crystals forming most of the day, but of their usual white colour.

Feb. 7.-Thermometer box shifted at $16^{\mathrm{h}} 10^{\mathrm{m}}$.

Feb. 8.-Robinson anemometer started after $12^{\text {h }}$.

Feb. 9.-Robinson anemometer tied up at $8^{\mathrm{h}}$. Thick crust of ice on louvres of thermometer box and all exposed 
surfaces all afternoon. Thermometer box shifted at $23^{\mathrm{h}}$ $20^{\mathrm{m}}$.

Feb. 10.-Thermometer box shifted at $10^{\mathrm{h}} 15^{\mathrm{m}}$. Double solar fog-bow seen at $11^{\mathrm{h}}$ to northward. Traces of red on outside of outer ring, and on inside of inner. Radius of outer bow, $42^{\circ} 4^{\prime}$; inner, $33^{\circ} 0^{\prime}$. Moon gleaming at night, but no corona observed.

Feb. 12.-At $12^{\mathrm{h}}$ rain-gauge found full of drift. At $18^{\mathrm{h}}$ rain-gauge undercut, and leaning over to one side.

Feb. 13.- Thermometer box shifted at $21^{\mathrm{h}} 20^{\mathrm{m}}$.

Feb. 14.-At $11^{\mathrm{h}}$ glory and fog-bow (see fig. 7). Outer radius of fog-bow, $45^{\circ} 12^{\prime}$; inner, $40^{\circ} 0^{\prime}$; radius of red of glory, $1^{\circ} 6^{\prime}$. Fog-bow tinged with red outside. Outside of glory red also. Seen on fog in northern valley.

$F e b .15$. - At $9^{\text {h }}$ solar halo, with portion of reverse halo on upper side of it. Large halo red inside, and blue outside; portion above red next sun and blue inside curvature. This upper arc overlapped on the main circle, bringing their reds together. The following measurements from centre of sun to the point where the two reds overlapped were made :-Radius, $21^{\circ} 42^{\prime} ; 21^{\circ} 49^{\prime} ; 22^{\circ} 0^{\prime}$; $22^{\circ} 0^{\prime} ; 22^{\circ} 0 ; 22^{\circ} 0^{\prime}$. The upper arc was very distinct, but the blue in it was fainter than in the main halo. Double solar corona at $11^{\mathrm{h}}$. Radius of outer red, $4^{\circ} 53^{\prime}$; inner red, $2^{\circ} 55^{\prime}$. Brown colour round and under sun all day. At $18^{\mathrm{h}}$ pinkish haze in air below the upper clouds and above the fog in the surrounding hills. From $19^{\mathrm{h}}$ to $23^{\mathrm{h}}$ lunar halo on cirrus, and for most of the time misty corona, also on cirrus. At $19^{\mathrm{b}}$ the following measurements were made.

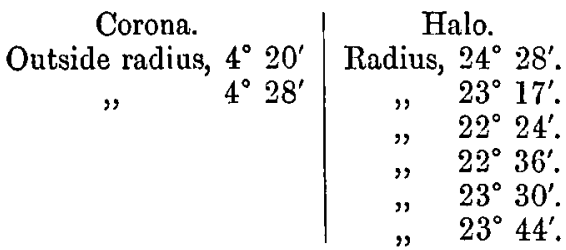

At $20^{\mathrm{h}}$ the measurements got were:-Radius of corona, $2^{\circ} 59^{\prime}$; halo, $21^{\circ} 13^{\prime}$. The corona was a mere bluish space with a red rim. No fog in valleys all day, but haze at horizon, especially to southward, and detached cumulus on hills.

$F e b .16$. - At $2^{\text {h }}$ misty corona on cirro-cumulus; colours Faint blue as in margin. Radius of red, $1^{\circ} 43^{\prime}$. Red Yellow D) Brown colour under moon at $4^{\mathrm{h}} 10^{\mathrm{m}}$. Similar colour at $5^{\mathrm{h}}$. At $7^{\mathrm{h}}$ watery glare in eastward sky, and purple colour to westward about $15^{\circ}$ to $30^{\circ}$ above horizon. Brown colour round sun all day, strongest on lower side. Dense haze in valleys to southward from S.E. to W. all afternoon. Earth shadow under rosy glow to eastward after sunset at $17^{\mathrm{h}} 30^{\mathrm{m}}$. Sun shone red through the haze as it sank into it. Upper glow began at $17^{\mathrm{h}} 40^{\mathrm{m}}$ and lasted till $18^{\mathrm{h}}$. Faint blue colour round moon at night. Long thin auroral arch at $23^{\mathrm{h}}$ and midnight. Height by stephanome $61^{\circ}$.

Feb. 17.-At $3^{\mathbf{h}}$ blue corona round moon. Brown colour under sun very faint to-day. Misty corona on cumulus at night. No measurements made.

$F e b .18$. White fog crystals forming all day.

Feb. 20.-Fog crystals brown in morning.

Feb. 21.-Fog crystals brown in morning, but white and more icy in texture at night.

Feb. 25.-Lunar corona at $5^{\text {h }}$, colours in following order out from moon:-White, yellow, red, violet, green, yellow, red. Pale reddish, or brown glare round sun all day, getting stronger near the horizon. Faint light to westward observed at $8^{\mathbf{h}}$; probably zodiacal light. Horizon hazy all day, especially to S.W. and W. Detached cumulus above haze to $S$. and $W$. in afternoon.

Feb. 26. - Solar corona observed at $12^{\mathrm{h}}$. Double rings varying in size. Radius of outer red, $8^{\circ} 22^{\prime}$; inner red, $4^{\circ} 34^{\prime} ; 4^{\circ} 23^{\prime} ; 3^{\circ} 38^{\prime}$. Similar corona at $13^{\mathrm{h}}$; the outer ring was only seen occasionally, and was too faint and fleeting to measure accurately, but was about $5^{\circ} 30^{\prime}$. Six measurements of the inner red gave as radius, $3^{\circ} 3^{\prime}$; $2^{\circ} 47^{\prime} ; 3^{\circ} 25^{\prime} ; 3^{\circ} 10^{\prime} ; 3^{\circ} 2^{\prime} ; 2^{\circ} 24^{\prime}$. Fog crystals white this morning.

$F e b .27 .-$ Top clearing of fog at times in afternoon. Fog crystals white, and very loose in texture and dry.

Feb. 28.-Fog crystals to-day pure white.

Mar. 4.-White glare in western sky at $18^{\mathrm{h}}$ and $19^{\mathrm{h}}$. Zodiacal light seen at $20^{\mathbf{h}}$; nothing seen in spectroscope. Thermometer box shifted at $18^{\mathrm{h}} 15^{\mathrm{m}}$.

Mar. 5.-At $8^{\mathrm{h}}$ fog-bow, corona (3, 4, and 5 rings), and glory ( 2 and 3 rings), on passing fog,-all too fleeting to measure. Thermometer shifted at $20^{\mathrm{h}} 5^{\mathrm{m}}$. Aurora seen at $22^{\mathrm{h}}$. To-day Wm. Stewart started to come up to the Observatory, but had to turn back, having lost his way in the dense fog before he got to Buchan's well. Mr Omond, Mr Rankin, and Mr Miller went down in search of him in afternoon. In consequence of this the $15^{b}$ observation was not taken till $15^{\mathrm{h}} 3^{\mathrm{m}} ;$ no corrections were applied to the various readings.

Mar. 6.-Double solar corona at $12^{\mathrm{h}}$. Faint aurora with a few streamers at night.

Mar. 7.-At $7^{\text {h }}$ thin pallium over sky to horizon, hills just clear under it. In the valleys to eastward there was an under glow of the same colour, and exactly similar to the upper glow seen before sunrise and after sunset. In this glow between Schehallion and Ben Nevis streamers were visible, which gradually receded and faded away as the sun rose higher. At $7^{\mathrm{h}} 13^{\mathrm{m}}$ the sun broke through the clouds, and at $7^{\mathrm{h}} 16^{\mathrm{m}}$ a white beam was seen stretch. ing vertically downwards from sun to the edge of Ben Nevis. It passed through a thin stratus cloud. Corcna observed at same time. The pallium broke up into detached masses like cumulus, but descending and settling over the bills round. At $7^{\mathrm{h}} 24^{\mathrm{m}}$ the beam was again seen

Double solar corona observed at $10^{\mathrm{h}}$

Radius of inner red, $3^{\circ} 46^{\prime}$. $\quad$ Outer red, . $\quad 7^{\circ} 30^{\prime}$.

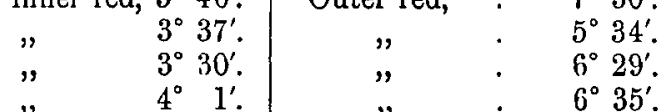

" $\quad 3^{\circ} 42^{\prime}$

, $\quad 3^{\circ} 42^{\prime}$.

" $\quad 2^{\circ} 50^{\prime}$.

The last measurement of the inner red, and the second measurement of the outer, were taken about the same time.

Halo observed at $11^{\mathrm{h}}$. The following measurements were made :-

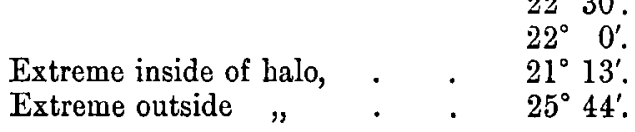


Same halo observed at $12^{\mathrm{h}}$.

Radius, $23^{\circ} 44^{\prime} ; 21^{\circ} 13^{\prime} ; 22^{\circ} 12^{\prime}$.

Dense haze coming up from S.W. beyond Mull in afternoon.

Solar halo at $13^{\mathrm{h}}$ also :-

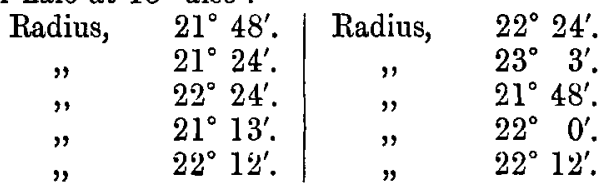

Horizon very dark, and sky mirky at night.

Mar. 8.-Brown crystals forming out of passing fog in afternoon.

Mar. 9.-Dense haze round horizon all day. At $17^{\mathrm{h}}$ three layers of upper clouds were observed. The highest was moving from W.N.W., the middle from S.W., and the lowest from S.E. The lowest appeared to be fed from above. The clouds came lower down in the evening, and then disappeared.

Mar. 10.-Thermometers shifted at $2^{\mathrm{h}} 8^{\mathrm{m}}$ and again at $3^{\text {h }} 8^{\mathrm{m}}$. At $6^{\text {h }}$, before sunrise, eastern horizon very red and reddish-brown glow on under surface of thin cirrus clouds. At $17^{\mathrm{h}}$ fog crystals slightly brown in colour were forming.

Mar. 11.-No brown colour under sun in forenoon, but faint colour in afternoon, and pale glare round sun.

Mar. 12.-At $12^{\mathrm{h}}$ bird (? raven) seen flying over hill. Distinct brown colour above haze under sun in afternoon. Sunset colours bright and very beautiful. Afterglow from $18^{\mathrm{h}} 30^{\mathrm{m}}$ to $18^{\mathrm{h}} 40^{\mathrm{m}}$. Sun sank into haze at $8^{\mathrm{h}} 23^{\mathrm{m}}$. For the last two days there has been dense haze all round, but especially to westward, rising to about 3000 feet, and very flat topped. When taking compass bearings along the path down the hill to-day Mr Rankin found that one of the large stones on the south side of the hill near the first gorge was strongly magnetic. It attracted the south end of the compass.

Mar. 13.- Fog crystals white to-day. Fleeting corona, sometimes single, sometimes double, formed on scud at night.

Mar. 15.-Fog crystals in morning very slightly grey in colour. Lunar corona on scud at night, too fleeting to nieasure.

Mar. 17.-Fog crystals rather hard and icy in early morning and during the day, but looser in texture at night. All pure white. Louvres of thermometer box a good deal choked.

Mar. 18. - Fog crystals brown in the afternoon.

Mar. 19. - Fog crystals brown in forenoon. Thermometer box shifted at $8^{\mathrm{h}} 10^{\mathrm{m}}$. The increase ( 1 inch) in the depth of snow to-day is probably due to fog crystals forming on the old roughened surface.

Mar. 20.-At 12h Robinson anemometer started.

Mar. 22.-Sky very ugly, both in clouds and colour, to S.W. all afternoon. At $13^{\text {b }}$ beams observed radiating from sun in every direction; some $20^{\circ}$ in length. Detached cumulus fog hanging about hills round all afternoon. Snow almost gone off the hills to north and north-east, and very streaky on the others. At $18^{\mathrm{h}}$ dark fog with haze below it advancing over hills to S.W. At $18^{\mathrm{h}}$ a ptarmigan, pure white, flew across the hill top. At $19^{\text {b }}$ green haze to N.E. The fog and haze to S.W. had reached Loch Leven. Fog on Ben Nevis at $20^{\text {h }}$; heavy rain and hail began shortly afterwards.

Mar. 23.-At $10^{\mathrm{h}}$ (wind S.S.W.) thin mist rising up from north valley close to cliff, but getting brushed back by the wind. At $15^{\mathrm{h}} 10^{\mathrm{m}}$ thermometer box shifted one stage down on ladder-stand.

Mar. 26.-Robinson anemometer tied up at $10^{\mathrm{h}} 5^{\mathrm{m}}$. Snow at night at first soft and in large flakes, but later on hard and icy.

Mar. 27.-At $13^{\text {h }}$ snow bunting seen on top. Thermometer box shifted at $22^{\mathrm{h}} 23^{\mathrm{m}}$.

Mar. 28. - At $10^{\mathrm{h}}$ three layers of cloud were observed, the lowest cum. from S.W., middle cir.-cum. from W. by N., and highest cir. and cir.-cum. from W.S.W. At $10^{\mathrm{h}} 15^{\mathrm{m}}$ vertical ascending columns of fog observed rising from Glen Nevis, and forming cum. clouds at about the level of the hill top.

Mar. 30.-No rain-gauge was out from $12^{\mathrm{h}}$ to $17^{\mathrm{h}}$, as the drift made it useless. Thermometer box shifted at $23^{\text {h }} 20^{\mathrm{m}}$.

Mar. 31.-Shower of hail between $16^{\mathrm{h}}$ and $17^{\mathrm{h}}$. The hailstones were hard and conical in shape, with spherical bottoms.

April 1.-At $16^{\text {h }}$ brown haze to S.W. very ugly looking, and cumulus above hills at N.W. horizon. Thermometer box shifted at $16^{\mathrm{h}} 15^{\mathrm{m}}$. At $18^{\mathrm{h}}$ rain-gauge buried out of sight in drift; none put out for the rest of the day. At $21^{\mathrm{h}}$ stars seen for a moment. The freshly fallen and drifted snow was much cut up by the wind at night.

April 2.-Short but very heavy hail shower at $8^{\text {h }}$. Rain-gauge was put out for the first time to-day at $9^{\text {h }}$.

April 3.-At $10^{\mathrm{h}}$ and several times during the afternoon rain-gauge was buried in drift. No gauge was put out at $21 \mathrm{~h}$. Thermometer box badly choked with drift all afternoon and night.

April 4.--Rain-gauge put out for first time at $4^{\mathrm{b}}$. Thermometer box badly choked with drift all day; the ozone papers were enclosed in a mass of snow over one inch thick.

April 5. - Thermometer box shifted at $11^{\mathrm{h}} 10^{\mathrm{m}}$.

A pril 6.-Top covered with deep soft, rather heavy snow.

April 7.-When the wind rose this afternoon, the soft snow blew about in blinding drift. At $13^{\mathrm{h}}$ the raingauge was buried so deeply that it could not be found. No gauge was put out after this. At $14^{\text {h }}$ it was impossible to see three yards for drift. Thermometer box considerably choked with drift at night.

April 8.-Rain gauge put out for the first time at $3^{\text {b }}$. At $11^{\mathrm{h}} 10^{\mathrm{m}}$ therunometer box shifted one stage higher on ladder-stand. Thermometer box shifted at $22^{\mathrm{h}} 15^{\mathrm{m}}$. This afternoon it was found that a drift about 10 or 12 feet high had gathered along the face of the cliff to N.W. during the recent storm. It did not overhang, but sloped back from the edge.

April 9.-At $17^{\mathrm{h}}$ top clearing at times; sunshine seen on southern hills.

A pril 10. - Thermometer box shifted at $10^{\mathrm{h}} 20^{\mathrm{m}}$. In the forenoon and middle of the day the fog rose gradually from the hills and formed cumulus over them. No fog in valleys all day. Loch Linnhe and Locheil calm all day, but surf breaking upon Eig. No unusual colours in sky.

April 11.-Loose cumulus floating about all day, but clearing entirely at night. At $19^{\mathrm{b}}$ yellow colour above sun and pink underneath. Aurora seen at $22^{\mathrm{h}}, 23^{\mathrm{l}}$, and midnight. Single arch, greatest height about $9^{\circ}$ by stephanome. 
April 12.-Aurora described yesterday was observed till $2^{\mathrm{h}}$. At $5^{\mathrm{h}}$ dark shadow observed to westward rising to about $14^{\circ}$; and at the same time faint glow in eastern sky. Brown colour round sun in forenoon, strongest underneath; none in afternoon, but only a faint glare round sun.

April 13.-Icy fog crystals forming in early morning. At $20^{\mathrm{h}}$ dense bank of cum.-fog in northern valley, rising to over 4000 feet, but standing clear of the hill side.

A pril 14.-At $10^{\mathrm{h}}$ fog-bow seen to northward rather broal and indistinct. At $17^{\mathrm{h}}$ glimpses of blue sky overhead. All afternoon icy fog crystals were forming.

A pril 15.-Misty corona at night.

April 16.-Thermometer box shifted at $0^{\mathrm{h}} 12^{\mathrm{m}}$. Misty coroua seen at times in early morning and at night. At $3^{\text {h }}$ very faint brown colour under moon. No brown haze round sun all day. At $8^{\mathrm{h}}$ bank of fog at $\mathrm{E}$. end of Ben Nevis, flowing down and vanishing. At $10^{\mathrm{h}}$ clouds over Glen Nevis at about 4000 feet above top, with a rotatory motion round horizontal axis, the southern or south-eastern side rising and the north or north-western side sinking. At $19^{\text {h }}$ haze in north-western valleys coloured yellow by sun shining down on it from behind clouds. After $23^{\mathrm{h}}$ clouds opened showing blue sky above the scud that was driving across the hill top.

A pril 17.-Great masses of cumulus fog all round Ben Nevis in forenoon. When the top cleared at $20^{\mathrm{h}}$ the southern hills were capped with dense cumulus, which gradually disappeared. Fragments of lunar halo seen at night, and faint brown colour under moon.

April 18.-At $19^{\mathrm{b}}$ the wind was E.S.E., but the fog was rushing up from northern valley, and passing overhead from N. to S., while above it and below it were eastsouth-eastern currents.

April 19.- Icy fog crystals forming in afternoon.

April 20.-At $19^{\mathrm{h}}$ solar halo observed. Radius of inner edge, horizontally, $23^{\circ} 17^{\prime}$; vertically, $22^{\circ} 0^{\prime}$. Faint brown colour under moon at night.

A pril 21.- In early morning fragment of lunar lialo observed several times. Sunrise colours are visible at $3^{\mathrm{h}}$. Faint solar halo observed in forenoon. Seven ravens seen at $13^{\mathrm{h}}$. No unusual colours round sun. Faint auroral arch at night. Meteor as bright as first mag.-star seen at $23^{\mathrm{h}} 5^{\mathrm{m}}$. It went from Pole-star toward W.N.W. horizon, and left a train about $10^{\circ}$ long at a height of about $50^{\circ}$, which remained visible for a second. No sounds heard.

April 22.-Faint brown colour under moon in early morning, and under sun at $7^{\text {h }}$. At $7^{\text {h }}$ fog low down about Loch Ness and Strathglass. At $14^{\mathrm{h}}$ pale glare round sun; sky very blue. This afternoon a new flexible shaft was put on the Robinson anemometer, and the instrument got a general overhaul. It was set agoing at $19^{\mathrm{h}} 30^{\mathrm{m}}$.

April 23.-Black bulb (old) was put out to-day on bracket stand at post A, 58 inches above snow. Double solar corona observed at $11^{\mathrm{b}}$. The following measurements were made :-

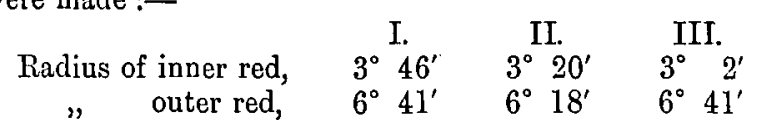

April 24.-At $8^{\mathrm{h}}$ spot of light forming part of solar halo was observed, coloured red, yellow, green, and blue, on north side of sun. Radius of red, $24^{\circ} 20^{\prime}$. At $9^{\text {h }}$ a complete halo, red inside, blue outside. Radius of red, $23^{\circ} 30^{\prime} ; 23^{\circ} 3^{\prime} ; 23^{\circ} 30^{\prime}$. Also double corona. Radius of inner red, $3^{\circ} 21^{\prime}$; outer red, $7^{\circ} 22^{\prime}$. At $10^{\mathrm{h}}$ it was found that the flexible shaft of the Robinson anemometer had got broken, probably owing to having been frozen fast near the top and twisted up.

April 25.-At $9^{\mathrm{h}}$ upper segment of halo seen on cirrus much higher than the general amount of cirrus at the time. At $17^{\mathrm{h}}$ solar halo seen. The following measurements were made :-Inside of red (radius), $23^{\circ} 3^{\prime} ; 23^{\circ} 3^{\prime}$; $23^{\circ} 3^{\prime}$; outside of red, $24^{\circ} 28^{\prime}$. The red colour was on the inside of the halo.

April 28.-This morning the sky under and around the sun was singularly clear and free from haze or glare.

April 29.-At $16^{\mathrm{h}}$ sun behind a cloud, but sky underneath all brown in colour. Faint auroral streamers to N.N.W. at $23^{\text {h}}$, and distinct but low auroral arch at mid. night.

April 30.-Thermometer box shifted at $23^{\mathrm{h}} 15^{\mathrm{m}}$.

May 1.-At $7^{\mathrm{h}}$ brown colour under sun. At $8^{\mathrm{h}}$ solar corona on passing fog. At $14^{\mathrm{h}}$ no brown colour or glare round sun. No fog in valleys all day, but dense haze round horizon all afternoon and night. Faint auroral light seen at $23^{\text {h }}$ and midnight.

May 2.-Portion of solar balo seen at $5^{\text {h }}$, the part above sun white and ill-defined, but bright red and blue spot to southward of sun ; radius of this red, $22^{\circ} 49^{\prime}$. At $7^{\text {h }}$ complete halo seen, red inside. Radius vertically, $23^{\circ} 3^{\prime}$; $21^{\circ} 48^{\prime} ; 22^{\circ} 49^{\prime}$; horizontally, $22^{\circ} 36^{\prime}$. Very thick dark haze all round during the day.

May 3.-Long icy fog crystals forming in early morning. May 5.-Dry and wet bulbs shifted at $3^{\mathrm{h}} 5^{\mathrm{m}}$.

May 6.-At $11^{\mathrm{h}}$ clouds passing over Ben Nevis from S., and passing down the north side into the valley.

May 7. - Solar halo in forenoon. A rough measurement at $10^{\text {h }}$ gave radius, $22^{\circ} 36^{\prime}$ (red inside). A better set of measurements at $12^{\mathrm{h}}$ gaveI.

Radius of red $(a), 22^{\circ} 36^{\prime}$.

$$
\begin{array}{lll}
\Rightarrow & (b), 22^{\circ} & 36^{\prime} \\
\prime & (c), 22^{\circ} 0^{\prime} .
\end{array}
$$

Radius of red $(a), 22^{\circ} 421^{\prime}$.

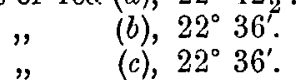

III. Radius of red $(a), 21^{\circ} 36^{\prime}$. $" \quad(b), 21^{\circ} 2^{\prime}$. IV. Radius of blue $(a), 14^{\circ} 28^{\prime}$. $\begin{array}{ll}" & (b), 24^{\circ} 28^{\prime} \\ " & (c), 24^{\circ} 13^{\prime} .\end{array}$

Measurements in II. and III. were taken alternately; II. being radius of red on upper side of halo, and III. on lower; red in III. not well defined. I. $a$ and IV.b were measurements of same portions of arc ; II. $b$ and IV. $c$ were measurements of same portions of arc. At $13^{\mathrm{h}}$ measurements got were-Radius of red upper side, $21^{\circ} 48^{\prime}$; $23^{\circ} 3^{\prime} ; 22^{\circ} 12^{\prime}$. Shortly after the measurements were made at $13^{\mathrm{h}}$, the cir.-str. clouds on which the halo was formed changed into cir--cum., and it disappeared, but soon came into view again on some filmy cir.-str. This afternoon the flexible shaft of the Robinson anemometer was repaired, and the instrument set going.

May 8.-Robinson anemometer was tied up at $7^{\mathrm{h}}$, but set going again at $10^{\mathrm{h}}$. At $17^{\mathrm{h}}$, however, it was found that the flexible shaft had broken again.

May 9.-Snow flakes at $7^{\text {h }}$ were very large-from $\frac{3}{4}$ inch to 1 inch in diameter.

May 10.-Thermometer box shifted at $1^{\mathrm{h}} 12^{\mathrm{m}}$. At $9^{\mathrm{h}}$ small bird, not a bunting, seen on roof.

May 11.-Dense rolling cumulus all round in after- 
May 12.--Thermometer box shifted at $1^{\mathrm{h}} 20^{\mathrm{m}}$. Faint upper are of halo seen at $5^{\mathrm{h}}$. $\mathrm{No}_{0}$ fog in valleys, but cumulus on hills round most of the day.

May 14.-Thermometer box shifted at $10^{\mathrm{h}} 30^{\mathrm{m}}$. At $17^{\text {h }}$ the wind was easterly $(2-3)$; but the sky was covered with cumulus at no great height, moving from N.N.W.

May 15.-Thermometer box shifted at $14^{\mathrm{h}} 15^{\mathrm{m}}$.

May 16.-Double lunar corona at $2^{\mathrm{h}}$ on low clouds, too fleeting to measure. At $3^{\mathrm{h}}$ cum.-fog on hills all round. At $4^{\text {h }}$ level-topped all over western hills. On this fog the shadow of Ben Nevis was clearly seen at $4^{\mathrm{h}} 10^{\mathrm{m}}$. Fog also on hills far to E. and N.E. Fragments of solar halo at $5^{\mathrm{h}}$. The snow which fell at night was small and hard.

May 18.-The snow that fell at night was hard and icy in texture.

May 19.-Thermometer box shifted at $22^{\mathrm{h}} 20^{\mathrm{m}}$. At midnight the northern horizon was faintly tinged with red by the sun.

May 20.- Faint brown colour under moon at $2^{\mathrm{h}}$. Brown colour under sun at $5^{\mathrm{h}}$. Solar halo at $7^{\mathrm{h}}$; colours faint, red inside. At $10^{\mathrm{h}}$ triple solar corona on scud; too fleeting to measure. Air very clear to S.W. in early morning.

May 21.-Dark, but not thick, haze in valleys at night. May 22.-Faint brown colour under moon at $1^{\text {h }}$. Brown colour under sun at $6^{\text {h }}$, and low fog on Loch Lochy. At $7^{\mathrm{h}}$ cloud above sun coloured red and blue in patches (about $5 \frac{1}{2}^{\circ}$ above the sun). When it came nearer

to the sun the colours vanished. There Red was no trace of arrangement in the colours. Blue The cloud of the cir.-cum. type. At $8^{\mathrm{h}} 3^{\mathrm{m}}$

Ber

Yellow

Green

Blue

Violet

Red

Yellow

White a similar cloud showed the same colours, but as this cloud approached the sun the colours formed a more regular corona, being arranged as in margin. Another cloud passed at $8^{\mathrm{h}} 6^{\mathrm{m}}$, giving similar colours; the violet and blue in this one were very bright. A third cloud passed at $8^{\mathrm{h}} 10^{\mathrm{m}}$, also with bright violet, blue, and green. A measurement of the inner red of this last gave for radius $3^{\circ} 31^{\prime}$. At $10^{\mathrm{h}}$ Ben Wyvis seen distinctly, and looking very high.

May 23.-At $4^{\text {h }}$ the sun was behind a thick bank of haze, and its disc scarcely discernible. A faint upper glow at about $45^{\circ}$ above the sun was seen. Solar corona at Red $12^{\mathrm{h}}$; colours as in diagram. Inner and Red and blue outer red distinct, but space between very mixed mixed in colour. Radius of inner red, mixed mixed in colour. Radius of inner red, - $\quad 6^{\circ} 41^{\prime} ; 6^{\circ} 35^{\prime} ; 6^{\circ} 41^{\prime} ; 6^{\circ} 41^{\prime}$ Very large haze all round last night and all to-day. At $16^{\text {h }}$ both cir.-cum. and cir.-str. were observed. The cir.-str. was distinctly below the cir.-cum., but was apparently moving in the same direction, S.S.W. At $20^{\mathrm{h}}$ the high cumulus appeared to meet the haze all round, leaving no clear sky. The rainfall at $21^{\mathrm{h}}$ is filled in by interpolation. The rain came on in short sharp showers, while the air was dry.

May 24.-At $18^{\mathrm{h}} 10^{\mathrm{m}}$ dry and wet shifted. During the dry fog to-day the air felt very close and warm.

May 26. - Thermometer box shifted at $16^{\mathrm{h}} 10^{\mathrm{m}}$.

May 27. - At $6^{\mathrm{h}}$ faint brown colour under sun. At $9^{\mathrm{h}}$ ascending currents from Glen Nevis forming cumulus clouds. At $13^{\text {ll }}$ bright halo seen; red inside, then yellow and blue outside. The following measurements were made :Radius of 1st, Red.

Yellow.

Blue. 2nd, $21^{\circ} 24^{\prime}$ $23^{\circ} 44^{\prime}$ $24^{\circ} 43^{\prime} k^{\prime}$ $3 \mathrm{rd}$, $22^{\circ} 0^{\prime}$ $22^{\circ} 49^{\prime}$ $24^{\circ} 43^{\prime} \longleftrightarrow$ 4 th, $22^{\circ} 12^{\prime}$ $23^{\circ} 30^{\prime}$ $24^{\circ} 13^{\prime} \uparrow$ $22^{\circ} 0^{\prime}$

$23^{\circ} 0^{\prime}$ $24^{\circ} 43^{\prime}$

The double arrows represent the diameters along which the four measurements were made.

May 24. - Thermometer box shifted at $4^{\mathrm{h}} 12^{\mathrm{m}}$. Fog rising from Glen Nevis in forenoon. Huge masses of cumulus all round at $13^{\mathrm{h}}$. Snow at $14^{\mathrm{h}}$ hard and dry. Air may have been dry.

May 21.-No colour round sun in forenoon, but at $15^{\mathrm{h}}$ a faint brownish glare was observed. A very faint afterglow was seen at $21^{\mathrm{h}}$. The door and windows were a good deal blocked up with drifted snow during the last week of May. They were dug out on 31st May, after being closed for four days.

June 1.-Brown colour under sun at $5^{\mathrm{h}}$ and $6^{\mathrm{h}}$. Fragment of halo, red inside, seen at $13^{\mathrm{h}}$. Haze to northward of a curious green colour at $22^{\mathrm{h}}$

June 3.- At midnight the higher cirrus clouds to northward were bright, apparently with sunlight; but the lower ones were quite dark.

June 4.-At $5^{\mathrm{h}} 10^{\mathrm{m}}$ halo and mock suns observed, halo red inside and blue outside. Mock suns at each side so bright as to be dazzling, the right hand one the briglitest. Radius from centre of sun to centre of mock suns, $23^{\circ} 17^{\prime}$. Vertical white segment below sun, and horizontal segment passing through mock sun. This horizontal segment was $12^{\circ} 32^{\prime}$ above the level-topped haze. At the right mock sun, the red of the halo was not broken, the white mock sun being outside it. The following measurements of the halo were made:-Radius of red, $22^{\circ} 36^{\prime} ; 22^{\circ} 36^{\prime}$ : yellow, $23^{\circ} 3^{\prime} ; 23^{\circ} 30^{\prime}$; blue, $23^{\circ} 44^{\prime} ; 23^{\circ} 44^{\prime}$. The mock sun to the left was coloured red, yellow, and blue in same order as the halo. At $8^{\text {b }}$ halo seen again, rather faint. Radius of inside of red, $22^{\circ} 0^{\prime}$; outside of red, $23^{\circ} 17^{\prime}$; outside of blue, $24^{\circ} 43^{\prime}$-measured on lower segment of halo. At $8^{\mathrm{h}}$ a corona was also observed on cir.-cum. Radius of inside of inner red, $2^{\circ} 50^{\prime}$; outside of inner red and inside of blue, $3^{\circ} 46^{\prime}$; outside of blue and inside outer red, $5^{\circ} 52^{\prime}$. Corona was faintly seen again at $13^{\mathrm{h}}$. No unusual colours round sun when clear of clouds.

June 5.-At $13^{\text {h }}$ the rain-gauge, which was buried out of sight on 7 th April, was found and taken in.

June 7 .-At $0^{\mathrm{h}} 10^{\mathrm{m}}$ thermometer box shifted one stage lower on ladder-stand. No glare round sun all day, but brown colour at western horizon at $16^{\mathrm{h}}$. Halo at $8^{\mathrm{b}}$. June 8.-Fog on hills to S.E. in early morning, which gradually spread over to Ben Nevis.

June $10 .-$ At $17^{\mathrm{h}}$ raven heard croaking, but not seen.

To-day Wm. Stewart, J. Macdonald, and one horse came up. The horse got right up to the Observatory, the snow being hard. This the first horse up this year.

June 11.-At midnight the dry and wet read $36^{\circ} \cdot 1$ and $35^{\circ} \cdot 2$, though the dry had a large drop of water hanging from it.

June 12.-At $14^{\mathrm{h}} 10^{\mathrm{m}}$ thermometer box shifted one stage lower on ladder-stand.

TRANS. ROY. SOC. EDIN, VOL. XXXIV. 
June 17.-At $22^{\mathrm{h}}$ a dark purple belt was observed to southward, rising from horizon to eastward, to $15^{\circ}$ above horizon to south-south-eastward, and sinking again to horizon to south-westward. At same time ordinary sunset colours were observed at north-western horizon. At $23^{\mathrm{h}}$ and at midnight the cirri clouds to northward shone with a bright silvery light (not auroral); the brightest parts were about $15^{\circ}$ above the borizon.

June 18. - From $21^{\text {b }}$ tillmidnight the roof of Observatory was quite wet with water blown by wind from face of precipice to north wards.

June 19.-Haze at horizon and over hills to-day till $22^{\mathrm{h}}$, when it cleared away.

June 20.-At $20^{\mathrm{h}}$ fog, which was observed during the afternoon to westward and north-westward, reached the Ben and began to drive over summit. At the same hour part of a solar halo, a fog-bow, and "glories" were observed. Part of a solar halo was also observed at $15^{\mathrm{h}}$; no measurements were obtained.

June 23. - At $0^{\mathrm{h}} 10^{\mathrm{m}}$ the thermometer box was lowered one step on ladder-stand.

June 28. - The $3^{\mathrm{h}}$ observation was not taken till $3^{\mathrm{h}}$ $11^{\mathrm{m}}$. No corrections applied to readings.

June 29.-At $12^{\mathrm{h}}$ the greater part of the clouds was evidently below the level of the top of Ben Nevis. In the afternoon, though there was fog on the hill top, the air was distinctly dry. To-day new rain-gauges, screw plug pattern, but higher in the rim than the last set, arrived at the Observatory.

June 30. -At $23^{\mathrm{h}} 5^{\mathrm{m}}$ dry and wet bulbs shifted.

$J u l y$ 1.-At $10^{\mathrm{b}}$ the lower clouds were distinctly of cir.-str. type. They formed to W.S.W. of Ben Nevis, and passed quickly overhead at a height of about 200 feet. There seemed to be a strong down current to eastwards of the Ben which sucked them down and made them vanish.

July 2.-At $15^{\mathrm{h}} 8^{\mathrm{m}}$ thermometer box shifted one stage down on ladder-stand.

July 3.-At $15^{\mathrm{h}}$ and $16^{\mathrm{h}}$, though the dry read higher than the wet, there was a large drop of water hanging from it.

July 4.--Dense cum.-fog over all the hills round at night, rising to over 4000 feet.

July 5.-At $22^{\mathrm{h}} 20^{\mathrm{m}}$ dry and wet bulbs put out in large thermometer box.

July 19. -The $20^{\mathrm{h}}$ observation was not taken till $20^{\mathrm{h}}$ $5^{\mathrm{m}}$. No correction applied to readings.

Aug. 3.-Very thin fog hanging round hill top, covering at times in early part of night. After $23^{\mathrm{b}}$ top was almost continuously enveloped, but fog was so thin that sky could be quite well seen.

Aug. 14.-At $13^{\mathrm{h}}$ solar halo observed; no colours visible. Measurement per stephanome of radius $=23^{\circ} 30^{\prime}$, $23^{\circ} 3^{\prime}$, and $22^{\circ} 36^{\prime}$.

Aug. 18.- In early morning sky almost completely covered with very high cumulus, which became slowly denser; a thin haze lying over the hills. At $3^{\mathrm{h}}$ the eastern sky was of a deep orange colour, there being a clear band of about $10^{\circ}$ between the horizon and the edge of the cloud. At $4^{\mathrm{h}}$ conditions were much the same, except that the clouds were tinged here and there with red. About $4^{\mathrm{h}} 15^{\mathrm{m}}$ white fog began to form on the hills. Sometimes dark strata were formed in the valleys, which thickened and became fog, and in some places detached masses of mist rose up in cumulus form, and after reaching a certain height folded in and became umbrella-shaped, with long filaments hanging down. Meanwhile the clouds above seemed to close in and descend, and at $5^{\mathrm{h}}$ they formed a thick pallium. The clear band to eastwards persisted after the sun had risen and gone above the edge of the pallium, after which it assumed a green colour.

Aug. 19.-At $3^{\text {b }}$ faint fog-bow observed, too large to measure. At $5^{\mathrm{h}} 50^{\mathrm{m}}$ two arcs of a bow were seen, centre apparently due west, on fog bank lying over west end of hill. The outer edges of these arcs were tinged with red. At $13^{\mathrm{h}}$ solar halo observed, radius $24^{\circ} 14^{\prime}$.

Aug. 20.-At $2^{\mathrm{h}}$ the surrounding hills were entirely covered with fog, which rose to a height of about $15^{\circ}$ on all sides, leaving the top of the Ben in the bottom of a sort of cup. The upper edge of the fog was almost quite level all round, and sharply defined. A faint lunar corona was observed, and appearance of stars indicated presence of a good deal of vapour. No clouds were observed except small quantity of cirrus.

Aug. 27. -At $20^{\mathrm{h}} 50^{\mathrm{m}}$ heavy hail shower commenced, changing to rain at $21^{\mathrm{h}}$. Rain continued, but air being very dry almost no record was given by gauges; stones, thermometer boxes, dc. remained quite dry till after $22^{\mathrm{h}}$.

Sept. 13.-Dense soft-looking fog in valleys to $W$. and $\mathrm{N}$. in early morning.

Sept. 14.-At $22^{\mathrm{h}}$ lunar fog-bow, white; and misty corona. Both formed on scud.

Sept. 15.-Fog in patches on hills in morning, and before sumrise dense fog over Loch Arkaig. Level sheet of fog covering eastern hills in the evening, and haze in the valleys round Ben Nevis.

Sept. 16.-Very thick haze in the valleys rising to rather above the level of Ben Nevis, all day, and blowing across the hill top as thin fog at night.

Sept. 17.-Haze similar to yesterday, but with patches of cumulus fog in it.

Sept. 18. - Dense haze and fog in valleys to about 4000 feet in early morning.

Sept. 19.-At $4^{\mathrm{b}}$ there was dense foggy-looking haze all round and below the Ben, but no corona or unusual colours at moon.

Sept. 21.-To-day the thermometer box and the black bulb were encrusted with snow and ice, the latter so much so as to render it impossible to set it at night. At $21^{\mathbf{h}}$ an aurora was observed having two arcs, from the lower of which short streamers were seen ascending. At $21^{\mathrm{h}} 5^{\mathrm{m}}$ a brilliant meteor was seen to south-westward at $45^{\circ}$ altitude, moving slowly towards S.E. It was so bright as to light up the upper room of the tower, and lasted for about 6 seconds. It made no audible noise. Its length was approximately from 12 to 15 yards. Before fading the head was yellow, the tail being of different colours, having a great amount of blue.

Sept. 22.-At $15^{\mathrm{h}} 20^{\mathrm{m}}$ the thermometers (dry and wet) were taken in, being too much encrusted with snow and ice for readingss to be satisfactory, and fresh dry bulb and wet bulb were put out.

Sept. 27. - At $5^{\text {h }}$ St Elmo's fire observed on lightning conductor. Thunder heard at $15^{\mathrm{h}} 33^{\mathrm{m}}$. Thunder and lightning at $19^{\mathrm{h}} 40^{\mathrm{m}}$. Several flashes of lightning between $20^{\mathrm{h}}$ and $21^{\mathrm{h}}$. Thunder, lightning, and earth currents about $23^{\mathrm{h}}$.

Sept. 28. - Lightning seen (one flash) at $3^{\mathrm{h}} 3^{\mathrm{m}}$; thunder heard at $5^{\mathrm{h}} 27^{\mathrm{m}}$.

Oct. 5.-Though no rain appeared to fall, the mist cou- 
tained large isolated drops of water both yesterday and to-day.

Oct. 6.-At about $18^{\text {h }}$ the hill top cleared, leaving fog over the lower hills and rather high clouds of cumulus type above. Thunder was heard at $17^{\mathrm{h}} 45^{\mathrm{m}}$, and distant thunder and lightning at $18^{\mathrm{h}} 5^{\mathrm{m}}, 18^{\mathrm{h}} 16^{\mathrm{m}}$, and several times about $21^{\mathrm{h}}$. At $19^{\mathrm{h}}$ lightning was seen in the distance to S.S.E. low down just above the fog. At $21^{\mathrm{h}}$ $38^{\mathrm{m}}$ a flash was seen, followed closely by thunder. At the time of the flash a sharp crack was heard in the tower stove-pipe, as if a discharge had gone down the lightning rod. Another flash, with a similar crack and followed closely by thunder, occurred at $21^{\mathrm{h}} 47^{\mathrm{m}}$. From $21^{\mathrm{h}} 40^{\mathrm{m}}$ to $21^{\mathrm{h}} 47^{\mathrm{m}}$ rain fell heavily, and the top was enveloped in thick mist. No thunder or lightning was observed between the flash at $21^{\mathrm{h}} 38^{\mathrm{m}}$ and that at $21^{\mathrm{h}} 47^{\mathrm{m}}$, and none after the latter; during that time the thunder-cloud seems to have been resting on, or crossing over, the hill top. No damage was done to the Observatory.

Oct. 7.-At $12^{\mathrm{h}}$ a solar fog-bow was observed. No colours, only a broad white band. Radius to inside of bow, $36^{\circ} 20^{\prime}$; outside, $43^{\circ} 36^{\prime}$. This afternoon the Robinson anemometer was taken down.

Oct. 10. - The ground to-day got all covered with dry snow about 2 inches deep.

Oct. 14.-At $23^{\mathrm{h}}$ misty lunar corona. Double ring, outer, blue inside the red, and inner yellowish. Size varying rapidly, brightest when largest. Radius of inner red, when of medium size, $2^{\circ} 26^{\prime}$.

Oct. 17. - The snow which fell early this morning was in large soft flakes, and was not hard and dry like the last.

Oct. 18.-To-day and yesterday evening the ground was all icy. Louvres of thermometer box badly choked at night, especially to windward.

Oct. 20.-At $10^{\mathrm{h}}$ the time error of the Observatory clock was found to be $+5^{\mathrm{m}} 5^{\mathrm{g}}$. It had been supposed to be only $+1^{\mathrm{m}} 30^{\mathrm{s}}$. The times since the 16 th have therefore probably a gradually increasing error, but no correction has been applied to any readings.

Oct. 21.-The fog or scud cleared overhead occasionally at $17^{\mathrm{h}}$ and $18^{\mathrm{h}}$, showing blue sky with some cirrus.

Oct. 22.-Fog-bow seen at $11^{\mathrm{h}} 25^{\mathrm{m}}$; colours as in fig. 8. The order of colours in the glory was not determinen. No measurement was got. The pink was a badly defined space, not a true band. Auroral streamers seen at $21^{\mathrm{h}}$; the arch appeared to be just about the horizon. Thick haze in the valleys and over the other hills at night.

Oct. 23.-Low fog over lochs in Caledonian canal valley at $8^{\mathrm{h}}$.

Oct. 24.-White icy fog crystals forming at night.

Oct. 25. - At $16^{\mathrm{h}}$ glory seen on fog to north-eastward. Rather misty and badly defined; four rings, inner one a mere blotch ; second, yellow and red - the brightest of the four : third, green and red; fourth only red seen clearly. The third and fourth were only seen occasionally. Radius of first red, $1^{\circ} 10^{\prime}$ (bad observation); second red, $3^{\circ} 46^{\prime}$; third red, $6^{\circ} 18^{\prime}$; fourth red, $7^{\circ} 22^{\prime}$; yellow in second ring, $2^{\circ} 55^{\prime}$; green in third ring, $4^{\circ} 31^{\prime}$.

Oct. 26.-Meteorite seen at $20^{\mathrm{h}} 2^{\mathrm{m}}$; started at about $60^{\circ}$ altitude to the E. by S., and fell almost vertically.

Oct. 28.-At $15^{\mathrm{h}} 7^{\mathrm{m}}$ dry and wet bulbs were shifted.

Nov. 2.-At $4^{\mathrm{h}} 5^{\mathrm{m}}$ St Elmo's fire seen on lightning con ductor, anemometers, and kitchen chimney. The brushes of light were broad-looking and bright. Hard dry snow was falling at the time.

Nov. 5.-At $18^{\mathrm{h}}$ lunar corona seen; colours as in margin (outer blue probably a margin). Radius of Blue red $2^{\circ} 17^{\prime}$ and of blue $4^{\circ} 43^{\prime}$. Well-defined Red halo seen all evening. The two following $D$ measurements were taken :-At $19^{\mathrm{h}}$, radius, $22^{\circ} 36^{\prime}$; at $20^{\mathrm{h}}, 22^{\circ} 0^{\prime}$. Fleeting corona also seen; colours as in margin. At $19^{\mathrm{h}}$ a light was seen to northward, possibly auroral. Heavy drift at night, making rain-gauges useless, but apparently no snow fell.

Nov. 6.-Very squally all morning, with strong back swirls in the wind. No gauge was out till $19^{\mathrm{h}}$, but probably no snow fell. At $14^{\mathrm{h}}$ the thermometers in the large thermometer box were taken in.

Nov. 7.-At $11^{\mathrm{b}}$, though the temperature was $21^{\circ}$, minute drops of rain were falling. Thermometer box shifted at $12^{\mathrm{b}} 25^{\mathrm{m}}$.

Nov. 8.- One of the Observatory horses was up for the last time this year.

Nov. 9. - The fog crystals forming to-day were slightly brown in colour. Thermometer box shifted at $15^{\mathrm{h}} 15^{\mathrm{m}}$. Fleeting misty double lunar corona, yellow inside and blue outside, seen at $21^{\mathrm{h}}$. Great masses of cumulus fog all round at night, and also over the southern hills.

Nov. 11.-At $8^{\text {h }}$ the shadow of Ben Nevis was seen on low clouds to N.W. and with it a badly-defined glory. A, portion of a solar halo was observed at $10^{\mathrm{h}}$ and also at $11^{\mathrm{h}}$. red inside. At $14^{\mathrm{b}}$ the western hills were topped with a sheet of fog reaching from about 2000 to 5000 feet in height, and extending from Mull to the extreme north. This rolled on and reached Ben Nevis at about $15^{\mathrm{h}}$. Thermometer box shifted at $8^{\mathrm{h}} 10^{\mathrm{m}}$.

Nov. 12.-Box shifted at $11^{\mathrm{h}} 30^{\mathrm{m}}$. Double fog-bow seen at $13^{\mathrm{b}}$; outer bow white, inner bow red and blue, red being inside. Faint single fog-bow (white) seen at $14^{\mathrm{h}}$. Lunar fog-bow and misty corona at $18^{\mathrm{h}}$. Triple corona at $19^{\mathrm{h}}$; colours as in margin. Radius of red, $1^{\circ}$ $2 \frac{1}{2}^{\prime}$; middle red, $2^{\circ} 29^{\prime} ;$ middle green, $2^{\circ} 3^{\prime}$. Size varying. Measurements were stopped by ice crystals from passing mist clogging stephanome. White fog-bow seen at same hour. Portion of halo seen at $21^{\mathrm{h}}$; radius,
Red Green Red Yellow Green Blue Red White D

$21^{\circ} 13^{\prime}$. Thin gauzy fog or mist filling valleys up to the level of top of Ben, and hiding hills round all night.

Nov. 13.-Fog similar to last night till $5^{\mathrm{h}}$, after which it rose and covered the hill top. The drizzling rain covered all exposed surfaces with ice.

Nov. 14.-Thermometer box shifted at $\operatorname{Red}$ $0^{\mathrm{h}} 15^{\mathrm{m}}$. Meteor seen at $5^{\mathrm{h}} 10^{\mathrm{m}}$. Triple Green lunar corona seen at $5^{\mathrm{h}}$; colours as in Blue margin. Radius of inner red, $1^{\circ} 23 \frac{1}{2}^{\prime} ; \quad$ Green middle red, $2^{\circ} 52^{\prime}$; outer red; $3^{\circ} 36^{\prime} ; \quad$ Green inner blue, $1^{\circ} 34 \frac{1}{2}^{\prime}$. At $7^{\mathrm{b}}$ red, green, and Red blue sunrise colours in eastern sky. At White $10^{\mathrm{h}}$ sky at north-eastern horizon sickly D green in colour; gloomy to N.W.

Nov. 16.-Fog-bow seen at $11^{\mathrm{h}}$, red outside and white inside. A fainter bow was seen inside this one at times. Nov. 17.-At $10^{\text {h }}$ the snow that was falling consisted of very small needle-shaped crystals.

Nov. 18.--Thermometer box shifted at $4^{\mathrm{h}} 20^{\mathrm{m}}$. Meteor 
seen at $5^{\mathrm{h}} 7^{\mathrm{m}}$ to W.S.W. Double corona (lunar) at $7^{\mathrm{h}}$; colours as in margin; too variable to Red measure. At $8^{\text {h }}$ shadow of Ben Nevis seen Blue $\quad$ as a dark gap in rosy sky to N.W. At $16^{\text {h }}$ Red distinct bank of stratus fog on hills of White Mull. Very clear to eastward and southDeastward all afternoon.

Nov. 21. - Thermometer box shifted at $3^{\mathrm{h}} 15^{\mathrm{m}}$. At $4^{\mathrm{h}}$ faint double corona and portion of lunar fog-bow seen. At $11^{\text {h }}$ portion of halo (red inside) seen. Broken bits of fog-bow down on Lochs Eil and Lochy in forenoon, but no continuous layers. Hills round almost clear of snow.

Nov. 23.-At $5^{\text {h }}$ and $6^{\text {b }}$ the dark part of the moon was clearly seen (new moon on 25th). Through a telescope the dark part looked light blue in colour, with large dark spots on the moon's surface. Though the fog lay all round up to about 4000 feet, no glories were formed on it, only patches of confused colour were seen at times. This evening the mist covered the top of the Ben, but so thinly that the stars were clearly seen through it, yet distinct drizzling rain fell. Faint aurora seen at night.

Nov. 24. - The dark part of the moon was seen again this morning similarly to yesterday. At $\tau^{\mathrm{h}} 20^{\mathrm{m}}$ long dark gaps like streamers in eastern sky. The sun rose at about $8^{\mathrm{h}} 12^{\mathrm{m}}$. Brown colour under sun at $9^{\mathrm{h}}$.

Nov. 25.-Auroral arch (low down) seen at $23^{\mathrm{h}}$, with faint streamers.

Nov. 26.-Meteorite (from Andromeda?) seen to westward at $0^{\mathrm{h}} 2^{\mathrm{m}}$.

Nov. 28. - Bright display of St Elmo's fire on lightning rod and anemometers at midnight, heavy but dry and hard snow falling at the time.

Nov. 29.-St Elmo's fire on lightning rod at $5^{\mathrm{h}}$, snow falling at the time. Thermometer box shifted at $9^{\mathrm{b}} 20^{\mathrm{m}}$. Nov. 30.-Thermometer box shifted at $12^{\mathrm{h}} 15^{\mathrm{m}}$.

Dec. 4.-Faint misty lunar corona seen several times in evening; too fleeting to measure.

Dec. 5.- Thermometer box shifted at $8^{\mathrm{h}} 20^{\mathrm{m}}$.

Dec. 6. -Thunder heard at $5^{\mathrm{h}} 44^{\mathrm{m}}$. Earth-current in telegraph cable about $10^{\mathrm{s}}$ before the peal was heard.

Dec. 7. - Thermometer box shifted at $4^{\mathrm{h}} 15^{\mathrm{m}}$. At $4^{\mathrm{h}}$ the dry (No. 192671) was below its scale, and the temperature of wet was assumed to be also that of the dry.

Dec. 8. - No rain-gauge was out from $4^{\mathbf{b}}$ to $10^{\mathrm{h}}$, as the drift made it useless, but apparently no snow fell. At $6^{\text {h }}$ and $7^{\mathrm{h}}$ the wind was so strong that it was impossible to go to the thermometer box. At $7^{\text {b }}$ Mr Rankin went out at the tower door tied with a rope, but found himself unable to stand. The fog crystals formed this morning were very slightly brown in colour. At $20^{\mathrm{h}}$ and $21^{\mathrm{h}}$ fleeting double coronas formed on scud.

Dec. 10.-T'Termometer box shifted at $22^{\mathrm{h}} 20^{\mathrm{m}}$.

Dec. 11.-Dry and wet bulbs shifted at $2^{\mathrm{h}} 10^{\mathrm{m}}$. The snow which fell at night was soft and heavy, and did not drift.

Dec. 13.-Faint afterglow observed at $16^{\text {h }}$. Bright single-arch aurora at $18^{\mathrm{h}}$. No streamers, and arch hazy at its edges. Luose cum.-fog hanging about the hill all day, and occasionally brushing the top. Sky very clear, and deep blue in colour.

Dec. 14.- - Very thin cirro-stratus in sky most of the day; the sun shone through it, though not strongly enough to record on the paper of the sunshine recorder. Portions of lunar halo seen several times at night.
Dec. 15.-Very squally, with back swirls at night. Had to use jacketed lantern. No gauge was out, but probably no snow fell.

Dec. 16.-Fleeting misty lunar corona at times in early morning; no measurements got. Glories and fog-bows at $15^{\mathrm{h}}$; too fleeting to measure. Glory double, with reds outside. Fog-bow as broad whitish band, with occasionally another bow inside it more sharply defined and coloured. Cum.fog hanging about the sides of the Ben all day.

Dec. 17. At $10^{\mathrm{h}}$ very small star-shaped snowflakes falling. At $14^{\mathrm{h}}$ air full of very fine needle-shaped crystals. The snow at night was ordinary snow-quite soft. At $14^{\mathrm{b}} 30^{\mathrm{m}}$ white vertical beam under sun, apparently stretching down into Glen Nevis. Faint misty glories seen at times in afternoon; no measurements got. Faint aurora seen at $21^{\mathrm{h}}$; no streamers, only a low irregular looking arch.

Dec. 18.-Misty faint glories seen in afternoon; too fleeting to measure. No gauge was out at night, but probably no snow fell, though there was considerable drift.

Dec. 19. - Thermometer box shifted at $10^{\mathrm{h}} 30^{\mathrm{m}}$. A faint auroral light seen to northward at night. Sky cloudless to horizon at night, but dark hazy look in the valleys below.

Dec. 20.-At $7^{\mathrm{h}}$ red, green, and blue sunrise colours at eastern horizon. Dark portion of moon clearly seen. At $9^{\text {lh }}$ two layers of cir.-cum., the higher radiating from S. by W. and the lower from S.W. Shadow of Ben Nevis seen on brownish-red clouds above the N.W. horizon; no glories or fog-bows about it. At $12^{\mathrm{h}}$ upper half of halo seen, red inside, white outside. Radius of middle of red, $21^{\circ} 54^{\prime}$; junction of red and white, $22^{\circ} 12^{\prime}$; middle of white, $23^{\circ}$ $58^{\prime}$. Distinct though small rain fell at $21^{\mathrm{b}}$, though the temperature was $18^{\circ} 0^{\prime}$. The fog crystals at night were white.

Dec. 23. - Snow at night large and soft.

Dec. 25.-The snow which fell to-day was large and soft. Measurements at night rather doubtful, owing to drift.

Dec. 26.-Thermometer box shifted at $0^{\mathrm{h}} 20^{\mathrm{m}}$. Fog on all hills to S.W., W., and N. during the day,-a level layer, but with roll-cum. top; it rose to about 3000 feet, but looked thin. At $10^{\mathrm{h}}$ a faint vertical halo stretching down from sun. At $12^{\mathrm{h}}$ a little drizzling rain and small dry snow were falling at the same time, temperature $19^{\circ} 4^{\prime}$. At $12^{\mathrm{h}} 30^{\mathrm{m}}$ misty glory and double fog-bow seen. Outside bow had red outside and inside bow red inside. No measurements got. No unusual colours near sun during the day ; sunset colours weak, and apparently no afterglow. Dark hazy look round horizon and under Ben all night. Aurora seen at night; single low arch. A few streamers (upwards) observed at $22^{\mathrm{h}}$.

Dec. 27.-At $9^{\mathrm{h}}$ shadow of Ben Nevis seen on clouds to N.W. above the horizon. Faint halo at $10^{\mathrm{h}}$. In the evening the snow was large and soft, but after midnight small and hard.

Dec. 29. - Thermometer box shifted at $17^{\mathrm{h}} 15^{\mathrm{m}}$.

Dec. 30.-At $10^{\mathrm{h}}$ small needle-shaped crystals of snow falling. Drizzling rain fell at $21^{\mathrm{h}}$, and a very little small hardish snow at $22^{\mathrm{h}}$. Fog crystals at night were white and icy. Double fog-bow seen at $11^{\mathrm{h}}$. Red outside outer bow and inside inner. The following (rough) measurements were got:-Radius of outside of outer bow, $41^{\circ} 22^{\prime}$; middle, $39^{\circ} 20^{\prime}$; inside, $36^{\circ} 36^{\prime}$; outside of inner 
bow, $34^{\circ} 44^{\prime}$; inside, $32^{\circ} 20^{\prime}$. The first and last measurements give the radii of the two reds. Misty glory seen at $15^{\mathrm{h}}$; colours as in fig. 9 ; the central part a confused mass of colour. Radius of red, $1^{\circ} 53^{\prime}$. Earth shadow seen to eastward at $16^{\mathrm{h}}$, and a very faint afterglow at $16^{\mathrm{h}} 5^{\mathrm{m}}$. Fog on hills to about 4000 feet all day.

Dec. 31.-Distinct icy hail fell in forenoon. At $13^{\mathrm{h}}$ the rain-gauge contained round icy particles like frozen rain drops. The rain covered everything with a coating of ice, three or four inches thick in some places.

\section{INSTRUMENTS IN USE DURING 1886.}

Barometer No. 1385 was in use during the whole of 1886 ; No. 1252 being occasionally read as a check.

For the Dry and Wet Bulb Thermometers, No. 192660, 192672, 192677 and 192671, all by Adie and Wedderburn; and also No. 50850 and 50852 , by Negretti and Zambra, but fitted with glass scales by Adie and Wedderburn, were used.

The Black Bulb in vacuo used was No. 186 by Hicks. Up to July 4, 5-inch rain-gauges were used, but after that date 5-inch gauges with higher rims were in use except when only rain was falling. All gauges made by Alexander Kemp, from drawings supplied by $\mathrm{Mr}$ Omond.

The Chrystal (Direction) Anemometer worked fairly well, and the Robinson (Velocity) Anemometer occasionally. On Oct. 7 it was taken down for the winter.

From July 1 to July 24 the brass-work of the Sunshine Recorder was under repair, and the papers were mounted in a temporary frame, which, however, worked well.

On Sept. 18 a new Chrystal Hygrometer arrived at the
Observatory, but there have been as yet very few opportunities of testing its working.

From July 6 to Nov. 5 inclusive, the Thermometers in use were placed in the large louvred box ; for the rest of the year in small boxes on ladder-stand. Max. 117293 and min. 116918 were used in large box ; and mins. 138533 and 138545 in small boxes. The depth of snow was always measured at post $A$.

The measurement of the rainfall was interrupted several times by drifting, and the ozone papers were occasionally blown away. Temperature readings were not got at $6^{\text {h }}$ and $7^{\text {hh }}$ on Dec. 8, owing to the high wind and dangerous drift. Otherwise the record is continuous, though once or twice the observation was a few minutes late.

Professor Ewing of Dundee sent during the summer a Seismometer, which was mounted on the stone slab in office, but which is not yet in satisfactory working order, owing, it is believed, to want of steadiness in the slab. From Aug. 14 to Sept. 4 the Cosmic Dust Collector was out.

The Barograph has worked most of the year, but its scale is seriously in error, a deflection of 2.25 inches on it corresponding to 1.00 inch on the Mercurial Barometer. It seems also to have been strained a little during the low pressure on Dec. 8.

The Thermograph has not been used.

The Hair Hygrometer has not been used.

The permanent staff of the Observatory consists as before of R. T. Omond, A. Rankin, and J. Miller.

From July 15 to Sept. $28 \mathrm{Mr}$ Gray (telegraph clerk) was also at the Observatory.

Messrs H. N. Dickson, J. T. Morrison, W. Hay, and J. Duncan took the places of some of the staff at various times.

\section{$188 \%$}

Jan. 1.-At $7^{\mathrm{h}}$ a very few large flakes of snow falling, each covering about one inch square.

Jan. 2.-At $18^{\text {h }}$ triple corona seen. Red outside in all three rings; outermost ring faint and evanescent. At times a fourth red was seen inside these surrounding white space near moon, but it was too small to measure (less than $50^{\prime}$ ). It was formed on scud; diameters seemed to vary. The following measurements were got:-Radius of innermost red, $1^{\circ} 22^{\prime}$; middle, $2^{\circ} 5^{\prime}$; outermost, $4^{\circ} 23^{\prime}$. When no scud was passing a blue corona was seen. Radius, $3^{\circ} 2^{\prime}$. Lunar fog-bow seen also at $18^{\mathrm{h}}$. Radius was about $38^{\circ} 40^{\prime}$

Jan. 3.-At $1^{\text {b }}$ rain-gauge was found undercut and leaning over. None was put out till $4^{\mathrm{h}}$. At $11^{\mathrm{h}}$ it was again found undercut, and none was ont till $17^{\mathrm{h}}$. Faint halo seen at $19^{\mathrm{h}}$; also triple corona. Red outside in all three rings. The following measurements were got:Radius of first red, $0^{\circ} 54^{\prime} ; 0^{\circ} 56^{\prime} ; 1^{\circ} 0^{\prime}$; second red, $1^{\circ}$ $48^{\prime}$; third red, $3^{\circ} 36^{\prime} ; 3^{\circ} 15^{\prime}$. Thermometer box shifted at $22^{\mathrm{h}} 20^{\mathrm{m}}$.

Jan. 4 .-At $6^{\mathrm{h}}$ narrow auroral arch seen, top about $11^{\circ}$ above horizon. No streamers. At $9^{\mathrm{h}}$ a bright goldencoloured corona round sun. No fog or haze in valleys, but a pink colour, like very thin haze, under the sun in the valleys. No gauge was out at night, but apparently no snow fell. Though the wind was high (force 7-8) there was little drift.

Jan. 5.-Solar corona seen at $13^{\mathrm{h}}$; Red $^{2}$ colours as in margin. Radius of red $^{1}$, Red ${ }^{1}$ $3^{\circ} 7^{\prime} ; \operatorname{red}^{2}, 6^{\circ} 12^{\prime}$; extreme outer edge White of red ${ }^{1}, 4^{\circ} 13^{\prime}$. Lunar corona seen at $D$ $22^{\mathrm{h}}$; colours as in margin. Radius of inner red, $3^{\circ} 20^{\prime}$; outer red, $6^{\circ} 29^{\prime}$; inner yellow, $2^{\circ} 36^{\prime}$; outer yellow, $5^{\circ} 22^{\prime}$. Yellow bands narrow, Red but green broad, and badly-defined. Jan. 6.-Thermometer box shifted at Ged $9^{\mathrm{h}} 30^{\mathrm{m}}$. Solar balo at $11^{\mathrm{h}}$ and $13^{\mathrm{h}}$. Red Yellow inside. Radius, $22^{\circ} 24^{\prime}$ and $22^{\circ} 6^{\prime}$. Misty White badly-defined lunar corona at night. Today the snow at the first gorge was measured, and found to be overhanging the cliff about 63 inches.

Jan. 8. - Halo seen at $1^{\mathrm{h}}$. Three measurements got. Radius to inside edge of halo, $21^{\circ} 36^{\prime} ; 22^{\circ} 0^{\prime} ; 20^{\circ} 51^{\prime}$. Solar corona seen at $11^{\mathrm{h}}$ (double). Radius of inner red, $3^{\circ} 31^{\prime}$; outer red, $6^{\circ} 7^{\prime}$. At same hours glory seen with four rings; larger than usual, and the colours broad and softlooking. The innermost red was only seen occasionally. Radius of second red, $4^{\circ} 46^{\prime}$; third red, $8^{\circ} 43^{\prime}$; fourth red, $12^{\circ} 6^{\prime}$. While measuring the glory a cloud passed to southward of Ben, and its shadow blotted out part of the
TRANS. ROY. SOC. EDIN. VOL. XXXIV.
$3 \mathrm{Y}$ 
three outer rings, but its shadow did not fall on the observer. At $12^{\mathrm{h}}$ portion of glory seen on clouds to north ward, though at the time the shadow of observer fell inside the edge of cliff (see fig. 10). At $14^{\mathrm{h}}$ faint brown colour under sun. At about $18^{\mathrm{h}} 3^{\mathrm{m}}$ lunar corona seen, while sky appeared cloudless. At $18^{\mathrm{h}} 6^{\mathrm{m}}$ stratus began to form to E.S.E., and at $18^{\mathrm{h}} 8^{\mathrm{m}}$ sky was overcast.

Jan. 10.- Faint brown colour under sun in afternoon. White dry fog crystals forming at night. No snow fell apparently at night during the height of the gale, as there was comparatively little drift.

$J a n$. 11.-Rain-gauge put out at $11^{\text {h }}$, as there was an icy crust on the snow, due to drizzling sleet and no drift going. The snow falling in afternoon was large, white, and rather hard.

Jan. 13.-Thermometer box shifted at $22^{\mathrm{h}} 15^{\mathrm{m}}$. Before this the louvres of box were badly choked with fog crystals and drift.

Jan. 14.-Lunar corona at $7^{\text {h }}$; colours as under-D white, yellow, red, violet, blue, green, yellow, red. Only seen occasionally; too fleeting to measure, and size apparently varying. At $13^{\mathrm{h}}$ small needle-shaped crystals of snow falling. At $17^{\mathrm{h}}$ (after sunset) faint upper glow with long streamers and purple glow to eastward from $15^{\circ}$ to $70^{\circ}$ above horizon. Bright aurora at $19^{\mathrm{h}}$; no streamers. On the upper side of the arch, a little on each side of the highest part there was a dark patch partly cutting the aurora through, and marked on the sky above; stars seen through it. At $23^{\mathrm{h}}$ the moon was just rising, very yellow. At midnight the dry bulb read $24^{\circ} \cdot 5$ and the wet $22^{\circ} \cdot 3$, yet in less than one minute after reading them very thin fog was blowing over the hill, giving a damp feeling to the air, and a double corona was formed on moon, inner very yellow, outer faint blue-green with red ring outside. Level-topped fog on hills to about 4000 feet at night, with haze above it.

Jan. 15.-Level shect of fog on all hills round, at about 4000 feet, all the early morning. Iunar corona at times formed by scud passing high up, though the air was very dry. Upper glow above a bright orange-coloured streak at eastern horizon at $8^{\text {h }}$. The fog on the hills broke up into detached bits of cumulus type in the forenoon, but haze formed round the horizon, and there was a brown colour under the sun in afternoon. At $16^{\mathrm{b}} 5^{\mathrm{m}}$ dry and wet shifted.

Jan. 16.-Thick dry fog crystals forming all day, slightly brown in colour.

Jan. 17.- No rain-gauge was out till $16^{\mathrm{h}}$, but apparently no snow fell before $11^{\mathrm{h}}$.

Jan. 18. - At $20^{\mathrm{h}}$ the rain-gauge could not be found, as it was buried in a drift. At $22^{\mathrm{h}}$, however, the snow had been so much cut away that the gauge was visible. No gauge was out after $20^{\mathrm{h}}$ till midnight.

Jan. 20.-Thermometer box louvres choked with hard ice all afternoon.

Jan. 21.-Thermometer box shifted at $18^{\mathrm{h}} 30^{\mathrm{m}}$. Before this the louvres were badly choked with ice.

$J a n$. 22,-Ice forming freely on all exposed surfaces again this afternoon.

Jan. 23.-From $20^{\mathrm{h}}$ till midnight an aurora was observed; single arch-no streamers. Louvres of thermometer box badly choked with ice all day.

Jan. 25. - Thermometer box shifted at $1^{\mathrm{h}} 30^{\mathrm{m}}$. Jan. 26.-Very heavy hail in early morning. The following order:- following measurements were got, but not entered in daily sheet, as the gauge evidently contained a large amount of drifted hail:-At $2^{\text {h }}, 1 \cdot 460$; at $3^{\text {h }}, 1 \cdot 733$; and at $4^{\text {h }}, 2 \cdot 233$. No gauge was out after $4^{\mathrm{h}}$ till $7^{\mathrm{b}}$. The squalls in early morning came in very sudden blasts.

Jan. 28.-A flash of lightning was observed at $6^{\mathrm{h}} 27^{\mathrm{m}}$. Strong earth-currents in telegraph wire at $6^{\mathrm{h}} 52^{\mathrm{m}}$ and at $7^{\mathrm{h}} 10^{\mathrm{m}}$.

Jan. 30.-The snow which fell at $16^{\mathrm{b}}$ and subsequently to-day was very small, but not hard. Thermometer box shifted at $18^{\mathrm{h}} 12^{\mathrm{m}}$.

Jan. 31.-Readings of rain-gauge very doubtful. At $11^{\text {h }}$ the gauge was found buried up to the rim, and none was put out till $21^{\mathrm{h}}$. The strong winds had blown so much of the late snowfall off that to-day the old surface hardened by the rain of last week was showing in several places. The fog crystals forming to-day were white and rather hard.

$F e b$. 2.-At $7^{\text {h }}$ the rain-gauge was found full of drift; none was put out after that till $17^{\mathrm{h}}$, but all the measurements got were unsatisfactory. Thermometer box badly choked up with fine drift during most of the day.

Feb. 3.-Thermometer box shifted at $9^{\mathrm{l}} 30^{\mathrm{m}}$.

$F e b$. 4. - At $5^{\text {h }}$ St Elmo's fire seen on lightning conductor and crystal vane, also faintly visible at $6^{\mathrm{h}}$. At $7^{\mathrm{h}} 2^{\mathrm{m}}$ bright flash of lightning, followed very closely by thunder. At $7^{\mathrm{h}} 7^{\mathrm{m}}$ earth-currents in telegraph cable, and $7^{\mathrm{h}} 25^{\mathrm{m}}$ another peal of thunder.

Feb. 5.-At $12^{\text {h }}$ the snow that was falling consisted of partly flat soft flakes and partly of hard white (haily) snow. The snow this evening was lying in waves from 20 to 50 inches long and about 2 inches high from trongh to crest.

$F e b .6$.-Lunar fog-bow and corona seen at $2^{\text {h }}$. Inside radius of fog-bow, $33^{\circ} 56^{\prime}$; outside, $40^{\circ} 20^{\prime}$-measured from shadow of head of observer. At $3^{\text {h }}$ faint brown colour under moon. Thermometer box shifted at $3^{\mathrm{h}} 20^{\mathrm{m}}$. Earth shadow seen to westward at $8^{\mathrm{h}}$ just before sunrise. Dense haze or fog hiding Mull all day. Brown colour under sun above this haze in afternoon, but no glare round sun. Earth shadow seen again after sunset.

$F e b .7$. - The drizzle from the mist this morning gave a brown colour to the snow, and the fog crystals were also brown.

$F e b$. 8. - At $7^{\text {h }}$ faint pink glow on thin cir.str. clouds $15^{\circ}$ to $20^{\circ}$ above eastern horizon. Sun rose just at $8^{\mathrm{h}}$. Dark brown colour under sun at $9^{\mathrm{h}}$. No afterglow at $17^{\mathrm{h}}$, but sky "smudgy." Double lunar corona at $23^{\mathrm{h}}$ and midnight. Rather indistinct, apparently formed on cir. clouds. Radius of inner red, $2^{\circ} 1^{\prime}$; outer red, $4^{\circ} 40^{\prime}$. No trace of a halo was observed on the cirrus. This afternoon the snow at the first gorge was found to be overhanging the edge of the cliff 172 inches.

Feb. 9.-At $6^{\text {h }}$ double lunar corona seen; colours in following order :-D, white, red, violet, blue, green, red. Radius of inner red, $1^{\circ} 45^{\prime}$; violet, $2^{\circ} 19^{\prime}$; blue, $2^{\circ} 50^{\prime}$; green, $3^{\circ} 15^{\prime}$; outer red, $4^{\circ} 0^{\prime}$. Brown colour under sun at $10^{\mathrm{h}}$, and again in afternoon. Haze, thickening into fog to W. and S., in valleys and over all lower hills to-day.

$F e b .10$. - At $4^{\text {b }}$ cum. fog was rising as high as the top of Ben out of corries to north-eastward, though dry and wet read 28.0 and $23 \cdot 2$. At $7^{\text {h }}$ the fog was rising higher than the Ben to S.E. and at $8^{\mathrm{h}}$ it covered the Ben.

$F e b$. 12.-Double lunar corona at $7^{\mathrm{h}}$; colours in 
Dhite. Red. Purple. Green. Yellow. Red. At $17^{\mathrm{h}}$ misty pinkish colour to westward below level of Ben. As the sun set the shadow of Ben was distinctly seen above the horizon to E.N.E. for a few minutes, until lost in the general earth shadow. The sun set into the sea, and as it disappeared a momentary bright green flash was observed. No afterglow was observed. At $21^{\text {h }}$ aurora, consisting of a bright single arch without streamers, was observed. Height of top of arch above horizon about $12^{\circ}$; width of bright part of arch, $2^{\circ} 15^{\prime}$. At $22^{\mathrm{h}}$ the arch was more irregular, being apparently made up of several superimposed on each other, and a few long streamers reaching nearly to the zenith were seen. The clouds which formed overhead in afternoon appeared to sink down as evening came on; though the sky was clear the air on the hill top was nearly saturated at $20^{\mathrm{h}}$, and it did not dry again till midnight.

$F e b$. 13. -Double fog-bow seen at $12^{\text {h }}$. Trace of red outside outer, and inside inner bow.

$F e b$. 15.-Bright light seen to nortliward through breaks in fog at $1^{\mathrm{h}}$, possibly auroral. A few passing glories seen at $14^{\mathrm{h}} 10^{\mathrm{m}}$. Solar corona observed on passing scud at $12^{\mathrm{h}}$, always double, sometimes triple; best seen when scud was uniform in thickness-not fibry-and thin enough to see the blue sky through.

$\begin{array}{ccccc}\text { Radius of inner red, } & 3^{\circ} 35^{\prime} & 3^{\circ} 31^{\prime} \\ , " & \text { outer red, } & 4^{\circ} 28^{\prime} & 5^{\circ} 43^{\prime}\end{array} \quad\left\{\begin{array}{ll}3^{\circ} 52^{\prime} \\ 6^{\circ} 55^{\prime}\end{array}\right\} \quad 3^{\circ} 21^{\prime} \quad\left\{\begin{array}{c}4^{\circ} 13^{\prime} \\ 7^{\circ} 38^{\prime}\end{array}\right\}$

The bracketed values were taken at as nearly as possible the same time. At $9^{\mathrm{h}} 20^{\mathrm{m}}$ the fog crystals on the stand for hygrometer were measured. Next the wood was one inch deep of white badly-defined and rather powdery crystals, then $\frac{3}{4}$ inch of brown well-defined feathery crystals, then $\frac{1}{1 \sigma}$ inch of pure white crystals, grown in last half hour. Between the $\frac{3}{4}$ layer and the $\frac{1}{10}$ inch layer was a belt of minute black specks which had apparently formed while the top was clear of fog. At $11^{\mathrm{h}}$ the cuter white layer was 0.55 inch long, showing a rate of growth of over $\frac{1}{4}$ inch per hour.

$F e b$. 16.-Brown fog crystals forming in early morning.

$F e b .17$.-Ice on all exposed surfaces in morning, but no trace of dust in it.

Feb. 18.-Thermometer box shifted at $22^{\mathrm{h}} 15^{\mathrm{m}}$.

Feb. 21.-Louvres of thermometer box choked with fog crystals and drift all yesterday and to-day.

$F e b .24$. - The snow which fell at night was dry and hard, and in rather large flakes.

$F e b .25$. - Thermometer box shifted at $19^{\mathrm{h}} 20^{\mathrm{m}}$. The measurements of amount of snow this afternoon are very doubtful, owing to drift.

Feb. 26.-Very thin film of cirrus over sky in early morning; stars showing through it. At $7^{\mathrm{h}}$ the under surface of the clouds to eastward was like sheets of flame, and the sky behind of a sickly pale green colour. At $7^{\mathrm{h}}$ $15^{\mathrm{m}}$ the colours had faded. Slight brown colour under sun at $13^{\text {h }}$. Sunset colours weak; no afterglow observed.

Feb. 27.-Dark haze mixed with small patches of cum.-fog round horizon and in valleys all day. Snow almost gone off other hills round. Dull "smoky" colours at sunset.

$F e b .28 .-$ Haze similar to yesterday in the valleys all day. Faint brown colour under sun at $16^{\circ}$.
Mar. 1.-Solar corona at $13^{\mathrm{b}} 10^{\mathrm{m}}$ on passing scud. Three rings, red outside in each. The following measurements were got :-

$\begin{array}{cccccc} & \text { I. } & \text { II. } & \text { III. } & \text { IV. } & \text { V. } \\ \text { Radius of first red, } & 1^{\circ} 46^{\prime} & \ldots & \ldots & 1^{\circ} 41^{\prime} & \ldots \\ , " \quad \text { second red, } & 2^{\circ} 26^{\prime} & 2^{\circ} 34^{\prime} & 2^{\circ} 39^{\prime} & 2^{\circ} 44^{\prime} & \ldots \\ , " \quad \text { third red, } & 4^{\circ} 8^{\prime} & \ldots & \ldots & \ldots & 4^{\circ} 40^{\prime}\end{array}$

At the same time a faint red corona seen on cirrus clouds when the scud cleared off ; radius about $0^{\circ} 56^{\prime}$. Thermometer box shifted at $15^{\mathrm{h}} 12^{\mathrm{m}}$. At $16^{\mathrm{h}}$ faint brown colour under sun. At $17^{\mathrm{h}}$ misty red colour under sun, and solar corona formed on scud. Three rings, red outside in all. The following measurements were got :-

$\begin{array}{ccccc} & & \text { I. } & \text { II. } & \text { III. } \\ \text { Radius of first red, } & . & 1^{\circ} 41^{\prime} & 1^{\circ} 25^{\prime} & 1^{\circ} 19^{\prime} \\ \prime, \quad \text { second red, } & : & 2^{\circ} 23^{\prime} & 2^{\circ} 26^{\prime} & 2^{\circ} 30^{\prime} \\ , " \quad \text { third red,. } & 3^{\circ} 54^{\prime} & \ldots & \ldots\end{array}$

At night lunar corona seen occasionally; too fleeting to measure. Fog crystals at night white and icy.

Mar. 2.-About half an inch of hard ice on all exposed surfaces this morning.

Mar. 3.-Ice forming freely on exposed surfaces all morning; no trace of dust in it. At $12^{\mathrm{h}}$ and $13^{\mathrm{h}}$ fog-bow seen, red outside; no other colours. Icy fog crystals forming in afternoon. After $18^{\mathrm{b}}$ the sky above was apparently clear, but banks of fog higher than Ben Nevis lay all round, and the hill top was of ten enveloped by this fog drifting over.

Mar. 4.-Glories seen on passing fog all day. At $11^{\mathrm{b}}$ $15^{\mathrm{m}}$ one seen from roof of Observatory, the shadow of observer falling on the snow about 10 yards away. Colours in following order :-Centre, white, red ${ }^{1}$, blue, green, red $^{2}$, blue, red ${ }^{3}$. Radius of red ${ }^{\prime}, 2^{\circ} 15^{\prime}$ and $3^{\circ} 12^{\prime}$ (inside and outside of colour). Another seen from edge of cliff at $11^{\mathrm{h}} 20^{\mathrm{m}}$; no fog-bow with it. Four rings of colours in order below. Measurements to outside edge of colour in each case. The radii appeared to vary slightly as the surface of the fog rose and fell.

$$
\begin{gathered}
\text { Radii. } \\
9^{\circ} 28^{\prime},
\end{gathered}
$$

Colours.

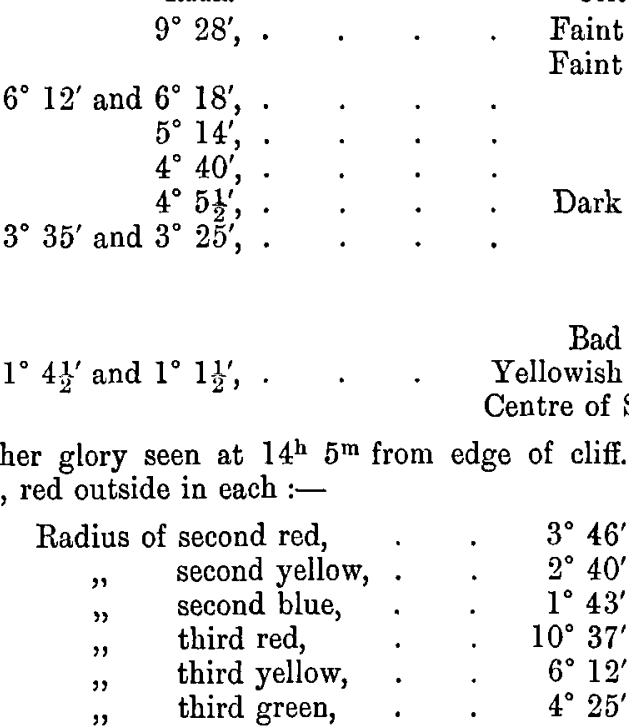

Bright glories, too fleeting to measure, were seen all afternoon on the loose fog drifting across the hill top. Solar corona seen at $11^{\mathrm{h}} 10^{\mathrm{m}}$; colours as follow :- 


$\begin{array}{cccc}\text { Radii. } & \text { Outer Edge. } & \text { Inner Edge } \\ \text { White } & & & \\ \text { Red } & 2^{\circ} 9^{\prime} & 2^{\circ} 27^{\prime} \text { and } 2^{\circ} 30^{\prime} & 1^{\circ} 40^{\prime} \\ \text { Dark } \begin{array}{l}\text { Blue } \\ \text { Green }\end{array} & 2^{\circ} 30^{\prime} & & \\ \begin{array}{l}\text { Red }{ }^{2} \\ \text { Dark }\end{array} & 3^{\circ} 54^{\prime} & 4^{\circ} 43^{\prime} \text { and } 4^{\circ} 37^{\prime} & 3^{\circ} 31^{\prime} \\ \begin{array}{l}\text { Green } \\ \text { Red }\end{array} & 6^{\circ} 48^{\prime} & & \\ \text { Dark } \begin{array}{l}\text { Blue } \\ \text { Green } \\ \text { Red }\end{array} & 7^{\circ} 59 \frac{1^{\prime}}{2} & \end{array}$

Another solar corona seen at $12^{\mathrm{h}} 10^{\mathrm{m}}$, colours and radii (outer edge of each colour) as under:-

White

Yellow

$\operatorname{Red}^{1} \quad 2^{\circ} 39^{\prime}$ and $2^{\circ} 39^{\prime}$

Dark Blue

Green

Yellow

Red ${ }^{2} \quad 4^{\circ} 46^{\prime}$

Dark Blue

Green

$\operatorname{Red}^{3} \quad 7^{\circ} 55^{\prime}$

Blue

Red ${ }^{4} \quad 9^{\circ} 41^{\prime}$

All the afternoon and evening very thick fog lay over the hills round, not a single hill top showing through till well on in the night, while the sky was cloudless, and with no trace of glare round the sun or moon and no brown colour under either. The sun set into the level-topped fog at $18^{\mathrm{h}} 2^{\mathrm{m}}$. The sunset colours at $18^{\mathrm{h}} 10^{\mathrm{m}}$ were red, pale yellow, and pale blue. No afterglow. Earth shadow distinct to east, with a red glow above it reaching to $45^{\circ}$ altitude.

Mar. 5.-At $3^{\text {h }}$ faint brown colour under moon. At $6^{\text {h }}$ $15^{\mathrm{m}}$ appearance of eastern horizon as in diagram. At $6^{\mathrm{h}}$

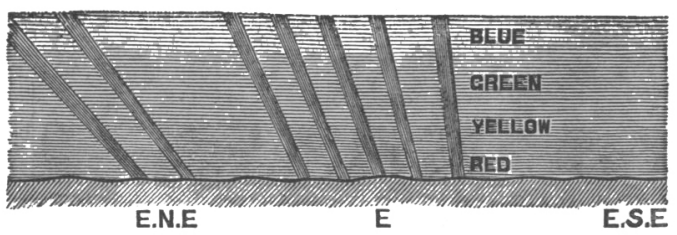

$20^{\text {nl }}$ red and orange colours rising higher, and gaps between the bright parts lengthening. At $6^{\mathrm{h}} 35^{\mathrm{m}}$ red almost gone, only faint traces of gaps left, and a faint pink glow about $12^{\mathrm{o}}$ above horizon. At $6^{\mathrm{h}} 45^{\mathrm{m}}$ only orange and yellow colours, then colourless or blue strips of sky, then pink glow; no gaps. Sun rose at $7^{\mathrm{h}} 2^{\mathrm{m}}$. Before and as it rose earth shadow $2^{\circ}$ high to west, with shadow of Ben Nevis about $22^{\circ}$ high distinctly marked in it. Brown colour under sun in morning and evening. Haze and detached cum.fog in valleys all day, but no continuous sheet of fog over hills, as there was yesterday. Earth shadow seen at sunset, and shadow of Ben Nevis still visible on cloud or haze to eastward after it had vanished. Sun sank into haze, but was seen through it down horizon. No green flash seen either when disappearing into haze or below horizon. Colour of sun above haze was yellow, and in haze red. Single arch aurora seen at night. Highest point of arch $16^{\circ}$ above horizon, breadth of arch about $4^{\circ}$ at $20^{\mathrm{h}}$. Streaks of cirrus and haze to south-west at night.

Mar. 6.-At $6^{\mathrm{h}}$ red and yellow sunrise colours seen. At $6^{\mathrm{h}} 50^{\mathrm{m}}$ a vertical beam of light starting from $5^{\circ}$ above the horizon to east and about $5^{\circ}$ long was seen; it lasted till the sun rose at $6^{\mathrm{h}} 56^{\mathrm{m}}$. One minute or so after the sun rose it appeared double. Solar halo seen between $9^{\mathbf{h}}$ and $10^{\mathrm{h}}$, as sketched (see fig. 11); colours as marked. The mock suns were red inside and blue outside; they lay distinctly on the outer edge of the halo. The following measurements were got:-

\begin{tabular}{cccc} 
& \multicolumn{2}{c}{ Left Mock Sun. } & Right Mock Sun. \\
Radius of red, . & $22^{\circ} 49^{\prime}$ & $23^{\circ} 17^{\prime}$ & $23^{\circ} 3^{\prime}$ \\
$"$ white, . $23^{\circ} 44^{\prime}$ & $24^{\circ} 13^{\prime}$ & $24^{\circ} 13^{\prime}$ \\
$"$ blue, . $24^{\circ} 28^{\prime}$ & $\ldots$ & $24^{\circ} 58^{\prime}$
\end{tabular}

Faint traces of green and yellow seen in the mock suns at $10^{\mathrm{h}} 10^{\mathrm{m}}$. The mock suns and horizontal white bar about $24^{\circ}$ above horizon at $9^{\mathrm{h}}$. The haloes, \&c., continued to be visible till $13^{\mathrm{h}}$. As the sun rose higher the horizontal bar curved upwards, and at noon the appearance of the inner halo and mock suns was more as in fig. 12. The bar also extended then inside halo. The following measurements were got at various times of the different parts :-

Sun to western mock sun, . . $23^{\circ} 46^{\prime}$

$"$ eastern $" .23^{\circ} 42^{\prime}$

" white circle E, . . . $\quad .79^{\circ} 56^{\prime}$

" $" \quad 2 \mathrm{~d}$ measurement, $\left.81^{\circ} 23^{\prime}\right\}$

"green at junction of $\mathrm{C}$ and $\mathrm{D}, 50^{\circ} 26^{\prime}$

Red of $\mathrm{C}$ to red of A, . $\quad .25^{\circ} 28^{\prime}$ and $24^{\circ} 48^{\prime}$

Blue of $\mathrm{C}$ to blue of $\mathrm{A}, \quad . \quad . \quad .25^{\circ} 13^{\prime}$ and $24^{\circ} 32^{\prime}$

Green of $\mathrm{C}$ to green of $\mathrm{A}$, . . . . $24^{\circ} 20^{\prime}$

At $12^{\mathrm{h}} 20^{\mathrm{m}}$ measurements were made of the wings between $A$ and $B$, $A$ point $P$ on one wing was taken and its distances $\mathrm{PS}=29^{\circ} 52^{\prime}$ from $Q, S$, and $Z$ (see margin) measured. $Q Z=28^{\circ} 56^{\prime}$ The wings were not arcs of same circle; $P Z=19^{\circ} 34^{\prime}$ judging by the old ring of stephanome, their centres of curvature lay about midway between the sun and the mock suns on either side. Haze with some patches of fog in valleys all day. Brown colour under sun in afternoon. Hock sun seen again at $17^{\mathrm{h}}$. Radius of red, $22^{\circ} 0^{\prime}$; of yellow, $22^{\circ} 36^{\prime}$; of blue, $23^{\circ} 17^{\prime}$. Faint lunar halo seen at $20^{\mathrm{h}}$. Single-arch aurora at $22^{\mathrm{h}} 30^{\mathrm{m}}$. At $22^{\mathrm{h}} 40^{\mathrm{m}}$ it broke up into a set of short vertical rays of rapidly varying place and brightness. At $23^{\mathrm{h}}$ it was gone. Its colour was greenish.yellow.

Mar. 7. -At $6^{\text {h }}$ sky green near horizon to eastward. At $7^{\mathrm{h}}$ faint double solar corona. Fleeting coronæ and glories were seen all day, but no measurements were got. Dense fog over the lower hills during the day, which occasionally blew across the top of Ben Nevis; but it cleared away at night, remaining longest on the hills to S.E.

Mar. 8.-Fog gathered again on the hills round in morning, and gradually rose till at about $14^{\mathrm{h}} 30^{\mathrm{m}}$ it covered Ben Nevis.

Mar. 9.-White dry fog crystals forming in early morning. At $11^{\mathrm{h}}$ thick haze with detached cum.-fog in it in valleys. The snow that fell in the afternoon was bard and dry.

Mar. 10.-The snow which fell to.day was light and dry, and drifted along the ground easily. The gauges 
were useless after $15^{\mathrm{l}}$ as they were found always either nearly buried or else undercut and lying over.

Mar. 11.-A rain-gange was put out at $8^{\text {h }}$, and they continued to be shifted till $15^{\mathrm{h}}$, but the readings were obviously worthless. No gauge was out after $15^{\mathrm{h}}$. Sky clear, but banks of cum.-fog all round higher than Ben Nevis at night. Dry and wet bulbs shifted at $22^{\mathrm{b}} 10^{\mathrm{m}}$.

Mar. 12.-Faint brown colour under sun in afternoon. Cum. at horizon all day, especially to westward.

Mar. 13.-At $4^{\text {b }}$ faint brown colour under moon. The recent fall of snow has been almost entirely swept off by the wind, leaving only patches or wreaths here and there.

Mar. 14.-Some passing showers were observed to-day near the horizon, and a little snow may have fallen on Ben Nevis, but the gauges were quite useless, owing to the light whirling drift brought up by the northerly wind from the cliff.

Mar. 15.-Masses of cum.-fog round Ben Nevis most of the day. A light-probably auroral-meen above this to northward at $21^{\mathrm{h}}$ and $23^{\mathrm{h}}$.

Mar. 16.-Aurora, single arch, no streamers, seen at $2^{\text {h }}$ and $3^{\mathrm{h}}$. At $5^{\mathrm{h}}$ red, green, and blue sunrise colours seen. At $6^{\text {h }}$ faint pink upper glow above yellowish sunrise colours to eastward. After $6^{\mathrm{h}}$ dark arch of shadow seen to westward about $10^{\circ}$ broad at thickest part, and about $20^{\circ}$ above horizon. The sky above and below this was distinctly brighter than itself. By $6^{\mathrm{h}} 32^{\mathrm{m}}$ this arch had sunk down towards the horizon, and become the earth shadow; the sky above it was bright red. The sun rose about $6^{\mathrm{h}} 35^{\mathrm{m}}$, and at $6^{\mathrm{h}} 37^{\mathrm{m}}$ the shadow was still seen to westward, with the shadow of Ben Nevis showing still darker in it. At $6^{\text {h }} 40^{\mathrm{m}}$ the earth shadow was gone, but the shadow of Ben Nevis was still visible above the horizon. Views very clear in forenoon; Jura, Colonsay, and Oronsay clearly visible. Distinct brown colour under sun. At $11^{\text {h }}$ two mock suns, with faint trace of white horizental circle outside them, seen on apparently perfectly clear sky. No trace of $22^{\circ}$ halo. Radius of eastern mock sun, $25^{\circ} 13^{\prime}$. At $11^{\mathrm{h}} 15^{\mathrm{m}}$, however, a trace of cir.-str. was observed round and near the sun. After noon cum.-fog began to form on southern and western hills, and very loose fog to rise out of Glen Nevis.

Mar. 18.-Low fog in valleys not rising above 1000 feet, except in a few places in morning and on till $10^{\mathrm{h}}$, after which it broke up and rose as cum.-fog. Thin uniform sheet of cloud over the Ben most of the day. Thermometer box shifted at $15^{\mathrm{h}} 10^{\mathrm{m}}$.

Mar. 19.-Air very clear at sunset, Jura, Mull, and islands beyond being all visible. At $19^{\mathrm{h}}$ dark purple belt to eastward about $15^{\circ}$ above horizon, with streak of sky below it above the haze near the horizon. Dark haze all round horizon at night, with auroral light above it to N.W. and $\mathrm{N}$.

Mar. 20.--Very dark haze at horizon in early morning. At $14^{\mathrm{h}}$ a few hard rounded flakes of snow were falling, though the gauge recorded nothing; similarly at midnight, but the flakes then were soft. White fog crystals forming in afternoon.

Mar. 21.-Very thick baze in valleys in early morning, Locheil and Loch Linnhe invisible at $6^{\text {h}}$. At $6^{\text {h }}$ faint pinkish upper glow above red streak at eastern horizon. At $6^{\mathrm{h}} 7^{\mathrm{m}}$ earth shadow seen; at $6^{\mathrm{h}} 18^{\mathrm{m}}$ the top of it was about $15^{\circ}$ above horizon to westward. Sun appeared at $6^{\mathrm{h}}$ $22^{\mathrm{m}}$, and was all up at $6^{\mathrm{h}} 26^{\mathrm{m}}$. At $9^{\mathrm{h}}$ solar corona seen ; colours as in margin; no measurements got. Haze and cum.-fog all round all morning. A few soft snow flakes fell in afternoon. Probably no snow fell at night, though the gauge recorded a little, as there was a good deal of surface drift.

Mar. 22.-Fog crystals in morning loose and dry, and slightly brown in colour.

Mar. 23.-Several showers of hardish solid snow fell in the forenoon. Fog crystals at night hard and icy.

Mar. 24.-Louvres of thermometer box considerably choked with drift and crystals both yesterday and to-day.

Mar. 26. - Thermometer box shifted at $4^{\mathrm{h}} 15^{\mathrm{m}}$. Solar halo of $22^{\circ}$ seen at $8^{\text {h }}$, red inside and bluish white outside ; no measurements got. The snow at the first gorge was found this afternoon to be overhanging the edge of the cliff by 217 inches. Icy fog crystals forming in afternoon.

Mar. 27.-Very variable winds most of the day, and especially towards nightfall.

Mar. 29. -Thermometer box shifted at $22^{\mathrm{h}} 15^{\mathrm{m}}$.

Mar. 30.-At $6^{\text {h }}$, after the sun was up, the shadow of Ben Nevis was visible above the horizon to westward. At $7^{\text {h }}$ thin haze filled the lower parts of the valleys, but to S.W. there was above this another distinct streak of haze just touching the tops of the hills in Mull and Jura with quite clear air between. This streak was distinctly haze and not cloud. At $8^{\text {h }}$ the clear space had vanished, and stratus was beginning to form in the haze. At $8^{\mathrm{h}} 7^{\mathrm{m}}$ the sky was overcast. At $9^{\text {h }}$ the cloud formed an arch over Ben Nevis, moving with the northerly wind, and hanging down both to $\mathrm{N}$. and $\mathrm{S}$.

Mar. 31.-Strong back-swirls of wind in early morning and very heavy and sharp squalls coming in hammer-like blows.

April 1.-Strong back-swirls again to-day. Thermometer box shifted at $11^{\mathrm{h}} 25^{\mathrm{m}}$. A single-arch rather faint rainbow seen at $15^{\text {h }}$ [Temp. dry, $25^{\circ} 1^{\prime}$; wet, $23^{\circ} 9^{\prime}$ ]. Icy fog crystals forming all night.

April 4. - Thermometer box shifted at $11^{\mathrm{hh}} 30^{\mathrm{m}}$. At $12^{\mathrm{h}}$ and $13^{\mathrm{h}}$ hard snow falling in conical pieces having spherical bases ; diameter of base from $\frac{1}{20}$ to $\frac{1}{4}$ inch; angle at vertex $90^{\circ}$. Fleeting double lunar corona formed on scud at night, usual type, inner circle yellow and outer blue-green; no measurements got.

April 5.-At $0^{\mathrm{h}} 10^{\mathrm{m}}$ thermometer box put one stage higher on ladder-stand. At $3^{\text {h }}$ double lunar corona seen ; colours as in margin. Radius of $\operatorname{red}^{1}, 2^{\circ}$ $10^{\prime}$; yellow ${ }^{1}$ (about) $1^{\circ} 38^{\prime}$; red $^{2}, 4^{\circ} 13^{\prime} ; \quad \operatorname{Red}{ }^{2}$ Yellow ${ }^{2}$ $\begin{array}{lll}\text { rather faint. At } 4^{\mathrm{h}} \text { light seen to E.N.E., } & \text { Red }^{1} \\ \text { possible zodiacal. At } 20^{\mathrm{h}} \text { wind very squally } & \text { Yellow }^{1}\end{array}$ and variable. The lamp was blown out Bluish white twice, and the sling note-book blown away.

Lantern in jacket was used at $21^{\mathrm{h}}$ and $22^{\mathrm{h}}$. At $22^{\mathrm{h}}$ the door of the thermometer box was found torn off its hinges and lying on the snow; it had probably not been properly secured at $21^{\mathrm{h}}$. The dry and wet were, therefore, for that hour (22) exposed partly to radiation.

A pril 6. - Thermometer box shifted at $9^{\mathrm{h}} 30^{\mathrm{m}}$. At $10^{\mathrm{ht}}$ solar corona seen occasionally. At $19^{\mathrm{h}}$ stratus pallium overhead, but rosy and hazy light to westward below its edge. This reddish colour was also seen on the westward side of the hills to $\mathrm{S}$. and S.E.

TRANS. ROY. SOC. EDIN. VOL. XXXIV. 
April 7.-Layer of thin stratus overhead all day, with its lower edges often brushing the hills round; sun shining through it in patches. At $17^{\mathrm{h}}$ the sun's rays shining down into the haze that filled the valleys to westward light it up; the rays below the sun were brick-red, those to S.W. green, and those to N.W. bluish in colour. At $19^{\mathrm{b}}$ the clouds were coming lower and disappearing. At $20^{\mathrm{h}}$ the sky was cloudless. Faint brown colour under moon at $22^{\mathrm{h}}$.

April 8.-Faint sunrise colours visible at $4^{\text {h }}$. Stratus fog in thin sheet on hills to N. and E. in early morning. Broken cumulus on and over hills during the day.

April 9.--Thin stratus fog on hills again this morning, and thick haze mixed with smoke from burning heather in the valleys during the day. The haze seemed to be higher than the level of Ben Nevis; it showed above the horizon. Brown Broken cum. over hills also to-day. Faint Blue upper glow at $5^{\mathrm{h}}$. At $8^{\mathrm{h}}, 9^{\mathrm{h}}$, and $10^{\mathrm{h}}$ colours Creamy white above haze to N.W., as noted in margin. Heze The brown extended almost all round the Horizon horizon.

April 10.-Thick haze in valleys all day, but hill tops showing clear above it. The snow at the first gorge was found to be overhanging the edge of the cliff by 214 inches.

April 11.-No fog in valleys, but very thick haze; in the afternoon and at night the haze was higher, so that the hills round could scarcely be seen through it.

April 12.-At $5^{\text {h }}$ faint upper glow to eastward, and earth shadow to westward about $10^{\circ}$ high ; sky above it of a reddish colour. Brown colour under sun at $6^{\mathrm{h}}$ and $7^{\mathrm{h}}$. Detached cumulus lay among and on the top of the haze all to-day. Cum.-fog rising rapidly out of Glen Nevis, and vanishing at $11^{\mathrm{h}}$. At $18^{\mathrm{h}}$ bright spot on each side of sun like mock suns, but no trace of halo. Radius, $21^{\circ} 48^{\prime}$ Before $19^{\mathrm{h}}$ thin fog was brushing across the top. At midnight the upper half of the dry bulb was covered with small crystals of ice, while the bottom was quite clear.

A pril 13.-At $5^{\mathrm{h}}$ earth shadow seen to westward topped by a brownish red glow; also faint pink upper glow to eastward. At $19^{\mathrm{h}}$ bright red colour in valleys to westward, with at times gaps in it due to cloud shadows. Clonds forming above Glen Nevis at above 4600 feet height, indicating ascending currents. At $20^{\mathrm{h}}$ fog all round.

April 14.-At $13^{\mathrm{h}}$ a cum.-cloud lying $35^{\circ} \mathrm{S} . \mathrm{W}$. of sun was seen to be very green on side next sun, and slightly pink on the further side. No brown colour under sun today, but haze mixed with smoke from burning heather in the valleys all day.

April 15.-Very small fine snow falling most of the day, too little to affect gauge.

April 16.-Aurora, single arch, no streamers, seen at midnight.

April 18.-Fog crystals forming all day, very hard and icy at night.

April 19.-Thermometer box shifted at $19^{\mathrm{h}} 15^{\mathrm{m}}$.

April 24.-The snow which fell to-day was mostly large and rather hard-often conical in shape; the drift, therefore, did not rise high, though the top was thickly covered with soft fresh snow.

April 25.-Heavy shower of hard conical snow at about $14^{\mathrm{h}} 15^{\mathrm{m}}$.

April 28.-Heavy masses of cumulus round Ben Nevis and over the surrounding hills all day. Thermometer box shifted at $10^{\mathrm{h}} 30^{\mathrm{m}}$. About a dozen peals of thunder heard between $17^{\mathrm{h}} 25^{\mathrm{m}}$ and $18^{\mathrm{h}} 20^{\mathrm{m}}$. No lightning seen, but at from 35 to 40 seconds before most of them earth currents moved the needle of telegraph instrument.

April 29.- -Sky well covered with loose detached cumulus and cirro-cumulus all day. At $9^{\text {h }}$ these clouds were observed to be coloured red, green, and blue, when passing near or over the sun ; one cir.-cum. cloud lying a little below the sun was red in its centre and blue all round towards its edges. At $17^{\mathrm{h}}$ there were two layers of cir.-cum., the upper moving from W.N.W. and the lower apparently from S.W. The cumulus or "lower clouds" were at the same time moving from N.E. Sun set at about $20^{\mathrm{h}} 5^{\mathrm{m}}$ behind the hills of Skye; horizon to N.W. rather hazy.

April 30.-All lochs almost perfectly calm all morning. Sky cloudy during the day, but air very clear underneath, and especially to W. and S.W. except when loose cumulusfog rose from the glens near Ben Nevis.

May 1.-At $4^{\text {h }}$ faint upper glow seen to north-eastward. At 11 there was both cirrus and cir.-cum. in the sky, the former being much higher than the latter, also a trace of a halo. At the same hour fog lay over all the hills round, and occasionally passed across Ben Nevis. Dark heavy bank of cumulus, with a clear streak below it, to westward all night.

May 2.-At $10^{\mathrm{h}}$ the dry bulb had fog crystals on its windward (or south) side, and a film of ice on the north side; while the wet bulb had no crystals on south side, but on the north side had long loose ones. (? Eddy of wind in box.)

May 3.-Solar corona at $10^{\mathrm{h}}$; colours as in margin ; no measurements got. Haze in valleys and cum. over hills all morning, but air clear.

May 4.-The snow which fell this evening was soft and in large flakes.

May 5.-This morning the fog crystals were slightly brown in colour. Loose cumulus fog rising all round in the middle of the day, and very dark haze in the valleys towards evening.

May 6.--Fog crystals brown in morning. Very dark haze almost hiding the nearest hills in afternoon.

May 7.--This afternoon the depth of snow at the first gorge was found to be 76 inches. The snow in the gorge overhangs the edge by 243 inches.

May 11. - Thermometer box shifted at $9^{\mathrm{h}} 25^{\mathrm{m}}$.

May 12,--At $3^{\text {h }}$ low strips of fog in valleys to north. ward.

May 13.-At $8^{\text {h }}$ fog was rising from Glen Nevis, and getting blown away by the north wind. At $11^{\mathrm{h}}$ pink coloured cloud, with upper part under sun coloured as in margin. Length of cloud, $103^{\circ}$; breadth, $6^{\circ} 30^{\prime}$; radius of green (only distinct line of colour), $12^{\circ} 36^{\prime}$. Cloud vanished suddenly, leaving a halo on cirrus much higher

Blue

Green Red

up. Shortly afterwards the halo got more distinct; it had inside it another ring, as in fig. 14. The outer ring was a distinct halo, with red inside and blue out; radius of red, $22^{\circ} 12^{\prime}$. The inner ring had a faint trace of red inside; radius of this red, $17^{\circ} 54^{\prime}$. By $11^{\mathrm{h}} 15^{\mathrm{m}}$ all had disappeared. Coloured clouds were seen again several times during the day; and at $17^{\mathrm{h}}$ a halo was again observed. The following measurements were got:-Radius of red, $21^{\circ} 54^{\prime}$ and $22^{\circ} 12^{\prime}$; yellowish green, $23^{\circ} 17^{\prime}$ and $23^{\circ} 17^{\prime}$; 
blue, $24^{\circ} 28^{\prime}$ and $24^{\circ} 13^{\prime}$. No trace of an inner ring was visible.

May 15.-Cum.-fog round Ben Nevis in forenoon, and cum.-clouds overhead in afternoon.

May 16.-At $0^{\mathrm{h}} 7^{\mathrm{m}}$ the thermometer box was put one stage down on ladder-stand. Haze round horizon all day, often rising so as to form cloudy patches, with clear sky under them.

May 18.-At $8^{\text {h }}$ hard conical-shaped snow falling. At night the snow was soft, and in large flakes.

May 22.-Thermometer box shifted at $15^{\mathrm{h}} 15^{\mathrm{m}}$. The northern horizon was faintly red all night.

May 23.-At $3^{\text {h }}$ low fog was lying over Loch Eil.

May 26.-Faint solar halo seen at $12^{\mathrm{h}}$ and $13^{\mathrm{h}}$. Snow almost gone off hills round. At $4^{\mathrm{h}}$ two strangers with a horse came up. This is the first horse up this year.

May 27.- Solar halo seen at $11^{\text {h}}$; colours strong, red inside and blue outside; but ring very broad, and edges badly defined. The view to $S$. and $E$. was very clear in afternoon, but haze formed there at night. Dense cumulus fog hid all the hills to northward at night; it extended to at least 4000 feet. To-day William Stewart and J. Rankin came up with two horses with stores, for the first time this year ; the horses came right up to the Observatory over the snow.

May 28. - The air was so dry that the wet bulb had to be moistened a few minutes before every hour till $9^{\mathrm{h}}$; it did not remain frozen more than 10 minutes at a time. Dense fog lay over the northward and eastward hills till noon, when it broke up and disappeared. It gathered again in the same manner in the evening. The moon ( 6 days old) was visible all afternoon.

May 29.-At $3^{\text {h }}$ a distinct upper glow was seen to north-eastward. No unusual colours were seen round the sun during the day. Fog on hills round all day, except for a few hours in the afternoon.

May 30.-At $0^{\mathrm{h}} 5^{\mathrm{m}}$ thermometer box was shifted one stage down on ladder-stand. Continuous fog over all the lower hills till $10^{\mathrm{h}}$, after which it began to break up and rise as cumulus. Upper-glow seen at $3^{\text {h }}$. Horizon and valleys hazy all day.

May 31.- Low fog lay in the valleys till $8^{\text {h }}$, after which it broke up, and cumulus clouds formed. Thick haze round the horizon all day, and at night heavy clouds above and mingling with it.

June 2.-Low fog in valleys to N. and N.E. in early morning, especially over Loch Oich. A faint solar halo was seen at $17^{\mathrm{h}}$

June 3.-In early morning str.-fog on Moor of Rannoch and in valleys among the hills to N.W. It cleared off about $9^{\mathrm{h}}$. Solar halo seen at $11^{\mathrm{h}}$ and $12^{\mathrm{h}}$. At $11^{\mathrm{h}}$ radius of red, $22^{\circ} 18^{\prime}$; blue, $22^{\circ} 43^{\prime}$. At $12^{\mathrm{h}}$ solar halo was observed, red inside and blue out, colours bright. Outside this halo on the S.E. side was a segment, coloured red inside, that appeared to cut into the halo, but did not extend inside it (see fig. 15). Radius of inner red, $22^{\circ} 18^{\prime}$ and $22^{\circ} 0^{\prime}$; outer red at furthest point from sun, $25^{\circ} 28^{\prime}$. At $15^{\mathrm{h}} 10^{\mathrm{m}}$ dry and wet were put out in large box 35 inches above snow. Double readings were taken till midnight, but the small box values were entered on the daily sheet.

June 4.- The dry and wet bulb entries on daily sheet are now taken from the instruments in the large box.
June 5.-Loose cum.-fog hanging about all afternoon.

June 10.-A faint glory was seen on the fog to S.W. at $4^{\mathrm{h}}$; no measurements got. Fog on hills to 4000 feet in early morning. About $6^{\mathrm{h}}$ this fog rose above the level of Ben Nevis, but it was dry and no rain fell.

June 13.-At $23^{\text {b }}$ the mist broke overhead, and at midnight sky was clear, and fog over hills to S. and E. Northern sky green, with filmy cirrus above.

June 16.-After sunset and during the night the northern horizon, and the lower surface of the cir.-cun. clouds on the sky, were both dark red in colour.

June 18.-At $6^{\mathrm{h}}$ and $7^{\mathrm{h}}$ the sky was overcast, with a heavy thunder cloud. Thunder and lightning were noted at $6^{\mathrm{h}} 27^{\mathrm{m}}$, and thunder at $6^{\mathrm{h}} 31^{\mathrm{m}}$. Heavy rain fell while thunder-storm lasted. Dew formed on thermometer screens, black bulb, and Observatory roof at night.

June 20.-A segment of a solar halo was seen at $4^{\mathrm{h}}$ and a full halo at $6^{\mathrm{h}}$. No measurements were obtained.

June 21.-A faint "foreglow" was seen at $3^{\mathrm{h}}$, and at same hour the earth shadow seen to westwards was topped by a belt of rosy colour, having streamer-like gaps therein.

June 22.-At $22^{\mathrm{h}}$ pink afterglow observed. At midnight northern horizon red and green.

June 24.-At $3^{\text {h }}$ faint upper glow seen to N.E. and earth shadow to S.W. A faint afterglow was also seen at $22^{\mathrm{h}}$. At midnight $\mathrm{N}$. horizon red and green, with pearly-white cirrus clouds above it.

June 25. - At $2^{\mathrm{h}}$ a cloud bank was seen to south ward, not far off, about $6^{\circ}$ above horizon, of peculiar perpendicular columnar structure. Pink upper glow observed at $3^{\mathrm{h}}$, and a faint afterglow at $22^{\mathrm{h}}$. At $18^{\mathrm{h}}$ a wasp was seen on roof. For the past few days large numbers of flies have been all about the hill top.

June 26.-At $1^{\text {h }}$ pearly-white cirrus to northward. In early morning str.-fog gathered in the valleys; it rose higher in the forenoon, and about noon broke up into cumulus and disappeared.

June 27.--In early morning str.-fog again in valleys; it gradually rose till it covered Ben Nevis as well as all the other hills. The stones of the hill top, however, wore never wetted by this fog.

June 28.-Upper surface of fog layer was about the level of Ben Nevis all day, sometimes rising over it, but never sinking so low as to expose many of the other hills. At $20^{\mathrm{h}}$ a glory was seen. Three rings, badly-defined and too fleeting to measure, but the middle ring was distinctly the brightest. Red outside in all rings. Pearly-white cirrus reaching to about $30^{\circ}$ altitude at midnight to northward.

June 29.-Pink upper glow observed at $3^{\text {h }}$. Fog-bow, occasionally double, observed at $5^{\mathrm{h}}$ and at $6^{\mathrm{h}}$. Thick continuous fog over all the hills round in early morning. At $9^{\mathrm{h}}$ this had risen above level of Ben Nevis, and continued so all day. At night it cleared to northward, and pearly cirrus at about $20^{\circ}$ altitude was seen.

June 30.-At $3^{\text {h }}$ faint upper glow seen to north-eastward. Pink afterglow seen at $22^{\mathrm{h}}$. The fog cleared away gradually to-day, leaving only a general haziness in the valleys.

July 1 .-At $3^{\text {h }}$ faint upper glow seen. Thick foggylooking haze in the valleys all morning, rising into cum.fog in the forenoon. 
July 2.-Halo seen at $7^{\mathrm{h}}$; red inside ; rather broad and faint. Seen again at $9^{\mathrm{h}}$ and at $13^{\mathrm{h}}$.

July 6.-At $1^{\text {h }}$ bright pearly cirrus seen to northward. Underneath it at the northern horizon was dark rollcum.

July 8.-Dark ugly-looking haze all round in afternoon.

July 16.-Heavy ugly-looking cumulus all round at night, though hill top and sky pretty clear. Clouds to northward quite dark, though horizon faintly red at midnight.

July 17.--No afterglow was observed after sunset, though the sky was quite clear. At night bright pearly cirrus to northward, height about $12^{\circ}$, highest to N.N.W. all night, not following the sun round.

July 18. - No upper glow before sunrise.

July 20.-Thick fog over the lower hills in evening. At 21 earth shadow seen to south-eastward. Up to midnight pearly cirrus seen to northward.

July 21.-At $10^{\mathrm{h}} 50^{\mathrm{m}}$ a double glory was observed from edge of cliff. The following measurements were got:Radius of inner red, $1^{\circ} 57^{\circ} 36^{\prime \prime} ; 2^{\circ} 1^{\prime} 12^{\prime \prime} ; 1^{\circ} 59^{\prime} 14^{\prime \prime}$; radius of outer red, $3^{\circ} 18^{\prime} 0^{\prime \prime} ; 3^{\circ} 19^{\prime} 30^{\prime \prime}$. A double fogbow was also seen at times; red inside inner bow and outside outer bow ; the rest of the bows were white-no other colours. A solar halo was seen at $8^{\mathrm{h}}$; no measurements got. The fog on the lower hills gradually rose and covered Ben Nevis; at $9^{\mathrm{h}}$ and $10^{\mathrm{h}}$ it was about level with the top.

July 24.-Heavy showers of hail fell between $11^{\mathrm{h}} 55^{\mathrm{m}}$ and $12^{\mathrm{h}} 10^{\mathrm{m}}$. The hail shower at $13^{\mathrm{h}}$ came on from the south-westward. It was falling on the roof of the visitor's room about four seconds before any fell at the tower.

July 25.-A distinct shower of snow fell between $10^{\mathrm{b}}$ and $11^{\mathrm{h}}$; a little was seen lying at $11^{\mathrm{h}}$.

July 31 .-Rainbow seen at $18^{\mathrm{h}} 45^{\mathrm{m}}$; double, primary bow the brightest. Radius of red of primary, $42^{\circ} 48^{\prime}$ and $44^{\circ} 17^{\prime}$; secondary, $53^{\circ} 8^{\prime}$. Red ontside primary and inside secondary. Measurements made from centre of shadow of observer's head.

Aug. 2.-Soft-looking fog over all hills round at night. Northern horizon bright at midnight.

Aug. 3.-Between $4^{\mathrm{h}}$ and sunrise $\left(4^{\mathrm{b}} 25^{\mathrm{m}}\right)$ the earth shadow was visible. Thick fog over hills to 3000 or 4000 feet till about $10^{\mathrm{h}}$; after which it broke up gradually, first clearing away to northward. At $10^{\mathrm{h}}$ a butterfly flew over the roof. At $21^{\mathrm{h}}$ a faint upper glow was seen; the $\mathrm{N}$. and N.W. horizon remained red till after $23^{\mathrm{h}}$. To-day the repaired Robinson anemometer was set up.

Aug. 4.- - Haze and low fog in valleys in early morning. Cum.-fog all round during the day, and haze in valleys again at night.

Aug. 5.-Trace of halo seen at $12^{\mathrm{h}}$. Very thick haze all round most of the day and at night.

Aug. 10.-At $1^{\text {h }}$ Robinson anemometer was tied up, but it was set going again at $7^{\mathrm{h}}$.

Aug. 16.- No fog in valleys all day, but cumulus and cum.-fog hanging about hill tops, which at $19^{\mathrm{h}}$ surrounded Ben Nevis except to southward, where there was haze. At $20^{\mathrm{h}} 45^{\mathrm{m}}$ afterglow seen to N.W.

Aug. 17.-Low fog gathered in the valleys to northward between $2^{\mathrm{h}}$ and sunrise; about $5^{\mathrm{h}}$ it had risen to the level of the hill top, and the rest of the day was misty. Glory seen at $5^{\mathrm{h}} 7^{\mathrm{m}}$. Single ring badly defined, with occasional traces of second outer ring. Radius of red (two measurements), $3^{\circ} 42^{\prime}$ and $3^{\circ} 52^{\prime}$.

Aug. 19.-Glories seen about $9^{\mathrm{h}} 40^{\mathrm{m}}$. Two circles distinct and two others outside these indistinct. Red outside in all. The colour next the shadow was yellow; between its red and red ${ }^{2}$ was violet, and between red ${ }^{2}$ and red $^{3}$ green. No measurements got. A fog-bow was seen at $9^{\mathrm{h}} 45^{\mathrm{m}}$, with glory inside it round shadow. At $10^{\mathrm{h}}$ $22^{\mathrm{m}}$ another glory seen at cliff. Red outside radius, $2^{\circ}$ $36^{\prime}$. The violet was a deep band reaching nearly if not quite to the shadow. Two other measurements of different glories about the same time gave for radius of red, $3^{\circ} 4^{\prime}$ and $3^{\circ} 13^{\prime}$. Misty glories were seen at various times during the day. A rainbow was seen at $19^{\mathrm{h}}$. Flashes of lightning were observed far to southward at $22^{\text {h }}$ $4^{\mathrm{m}}$ and at about $22^{\mathrm{h}} 30^{\mathrm{m}}$.

Aug. 20.-At 3 low-lying fog over lochs and rivers to northward. Fog gradually gathered on the hills round, and by $6^{\mathbf{h}}$ covered Ben Nevis.

Aug. 21.-Glory seen at about $9^{\text {h }} 30^{\mathrm{m}}$; colours as in fig. 16. Yellow ${ }^{1}$ and red faint; yellow ${ }^{2}$ and red $^{2}$ very distinct. In 2 no green and in 3 no blue (or only faint traces in both cases). In ring 3 the green and red were the most distinct colours, yellow barely visible. When clouds or fog blew up the corrie where the glory was seen the colours got blurred and indistinct. The following measurements were taken:-Radius of yellow (inside), $2^{\circ} 36^{\prime}$ and $2^{\circ} 32^{\prime}$; junction of yellow ${ }^{2}$ and red $^{2}, 3^{\circ} 15^{\prime}$ and $3^{\circ} 29^{\prime} ;$ red $^{2}$ (outside), $4^{\circ} 25^{\prime}$ and $4^{\circ} 18^{\prime} ; \operatorname{red}^{3}$ (outside), $7^{\circ} 30^{\prime}$; green (inside?), $6^{\circ} 48^{\prime}$. At $20^{\mathrm{h}}$ faint afterglow observed.

Aug. 23. - At $5^{\mathrm{h}} 20^{\mathrm{m}}$ glory seen from window in tower door. Two and three circles seen, red outside in each. No measurements got.

Aug. 28.-At $14^{\text {h }}$ a rainbow was seen.

Aug. 31.-A shower of hail fell between $14^{\mathrm{h}}$ and $15^{\mathrm{h}}$. Thunder was noted at $16^{\mathrm{h}} 9^{\mathrm{m}}$, and again at $17^{\mathrm{h}} 0^{\mathrm{m}}$; no lightning seen.

Sept. 1.-At $22^{\mathrm{h}}$ an ill-defined white lunar halo was observed.

Sept. 2.-At $18^{\mathrm{h}} 45^{\mathrm{m}}$ part of a rainbow was observed to east-soutl-eastward.

Sept. 4.- At $4^{\mathrm{h}}$ a lunar corona was observed, arrangement of colours as shown in Yellow margin. It was too fleeting for measure- White ments to be obtained.

Sept. 6.- Snow and sleet fell between $18^{\mathrm{h}}$ and $19^{\mathrm{h}}$. At midnight the Robinson anemometer was tied up.

Sept. 7.-At $5^{\mathrm{h}}$ a lunar corona was seen. At $10^{\mathrm{h}}$ the mist cleared off summit, but lay in valleys and on hills around till $13^{\text {h }}$, after which it rose and formed into cumulus clouds overhead, leaving great "visibility" all round below.

Sept. 8.-A lunar corona was seen at $5^{\text {h }}$, but no measurements were got. At $7^{\mathrm{h}}$ the Robinson anemometer was untied, and for the rest of the day it went all right. Lightning was seen at $21^{\mathrm{h}}$.

Sept. 9. - The Robinson anemometer was tied up at $18^{\text {h }}$ $25^{\mathrm{m}}$. At $23^{\mathrm{h}}$ St Elmo's fire was seen on the tips of the lightning rod and on the vane. Its appearance was accompanied by a very audible fizzing, not crackling, like the sound emitted by water on a hot iron plate. A little snow was falling at the time, and the wind was rather gusty. It was observed that the light was brightest when 
the wind was strongest. At midnight the summit was white with snow.

Sept. 10.- Robinson anemometer was untied at noon.

Sept. 11.-Anemometer was tied at $16^{\mathrm{h}}$.

Sept. 12.-Heavy showers of snow fell this morning.

Sept. 14. - Anemometer untied at $8^{\mathrm{h}}$.

Sept. 15.-The summit was clear till $16^{\mathrm{h}}$, but fog. enveloped for the rest of the day. During the morning hours the lights of the S.W. coast lighthouses were easily seen. Robinson anemometer tied up at $20^{\mathrm{h}}$.

Sept. 16.-Between $3^{\mathrm{h}}$ and $4^{\mathrm{b}}$ this morning the zodiacal light was seen as a steel-grey glimmer extending from eastern horizon through the constellations Leo and Cancer, to the border of Gemini. At the same time a light, supposed to have been the glare of the Carron ironworks, was observed at the south-south-eastern horizon. Fog lay in valleys and on surrounding hills all day, rising in afternoon, and occasionally passing the summit. The anemometer was untied at $13^{\mathrm{h}}$.

Sept. 17.-Summit was clear after $6^{\text {h }}$. The sky was cloudless after $19^{\mathrm{h}}$ except for some thin stratus at $22^{\mathrm{h}}$. Fine pink afterglow observed from $18^{\mathrm{h}} 45^{\mathrm{m}}$ till $19^{\mathrm{h}} 5^{\mathrm{m}}$. Ice formed on top of thermometer screen at $21^{\mathrm{h}}$ and at midnight. A bright shooting-star was seen at $20^{\mathrm{h}} 11^{\mathrm{m}}$.

Sept. 18.-At $3^{\mathrm{h}}$ an aurora was seen low to northward with short and not very bright streamers. The zodiacal light was seen at $3^{\mathrm{h}} 30^{\mathrm{m}}$. The summit was clear till $15^{\mathrm{h}}$, but thick fog lay on lower hills all around, which gradually rose, and enveloped summit after that hour. At $12^{\mathrm{h}}$ and at $14^{\mathrm{h}} 30^{\mathrm{m}}$ glories were seen from edge of cliff to northward. At $13^{\mathrm{h}} 30^{\mathrm{m}}$ the following measurements were got :-

\begin{tabular}{|c|c|c|c|c|c|c|c|c|c|}
\hline$\ddot{\bar{\theta}}$ & $\begin{array}{c}\text { Red } \\
\text { glow. }\end{array}$ & $\begin{array}{c}\text { Inside } \\
\text { of } \\
\text { Red1. }\end{array}$ & Red1. & $\begin{array}{l}\text { Out- } \\
\text { sille of } \\
\text { Red1. }\end{array}$ & Blue. & Green. & $\begin{array}{c}\text { Inside } \\
\text { of } \\
\text { Red }^{2} \text {. }\end{array}$ & $\operatorname{Red}^{2}$. & $\begin{array}{l}\text { Out- } \\
\text { side of } \\
\text { lied? }\end{array}$ \\
\hline 5 & $\begin{array}{c}1^{\circ} 12 \frac{1^{\prime}}{} \\
\ldots\end{array}$ & $\begin{array}{c}2^{\circ} 56^{\prime} \\
\ldots\end{array}$ & $\begin{array}{l}3^{\circ} \mathbf{4} 4^{\prime} \\
3^{\circ} 35^{\prime}\end{array}$ & $\begin{array}{l}4^{\circ} 5^{5 \underline{1}^{\prime}} \\
3^{\circ} \mathbf{b}^{\prime}\end{array}$ & $\begin{array}{c}4^{\circ} 23^{\prime} \\
\ldots\end{array}$ & $\begin{array}{c}4^{\circ} 43^{\prime} \\
\ldots\end{array}$ & $\begin{array}{l}4^{\circ} 56^{\prime} \\
5^{\circ} 3^{\prime}\end{array}$ & $\begin{array}{c}5^{0} 34^{\prime} \\
\ldots\end{array}$ & $\begin{array}{l}6^{\circ} 24^{\prime} \\
6^{\circ} 29^{\prime}\end{array}$ \\
\hline
\end{tabular}

A fog-bow was observed at same time, measuring $35^{\circ} 16^{\prime}$. Sept. 19.-The fog cleared off summit after $17^{\mathrm{h}}$, leaving thick fog in valleys all round and a cloudy sky. From $21^{\text {h }}$ till midnight the sky was cloudless. At $23^{\mathrm{h}}$ a glimmering light was seen at northern horizon, probably auroral.

Sept. 20.-At $30^{\mathrm{b}}$ zodiacal light was seen looking as bright as the milky way. Fog in valleys till $4^{\mathrm{h}}$, after that cum.-fog on hills till about noon, and thick haze in valleys all afternoon and at night. At about $18^{\mathrm{h}} 45^{\mathrm{m}}$ the afterglow was seen faintly.

Sept. 21.-Fog lying over and hiding all the lower hills round most of the day. On this glories were seen frequently. The following measurements were got at $7^{\mathrm{h}}$ $10^{\mathrm{m}}$, colours as in fig. 16 :- Radius of $\mathrm{red}^{2}, 4^{\circ} 18^{\prime} ; 3^{\circ} 15^{\prime}$; $4^{\circ} 18^{\prime} ; 3^{\circ} 54^{\prime}$; yellow ${ }^{2}, 2^{\circ} 59^{\prime} ; 3^{\circ} 2^{\prime} ; 3^{\circ} 4^{\prime} ; 2^{\circ} 39^{\prime} ;$ blue $^{2}$, $2^{\circ} 17^{\prime} ; 2^{\circ} 21^{\prime} ; 2^{\circ} 24^{\prime} ; 2^{\circ} 12^{\prime}$. After $8^{\mathrm{h}}$ the following measurements were taken, some from top of tower and some from edge of cliff. The glory appeared to vary in size as different parts of the fog drifted past.

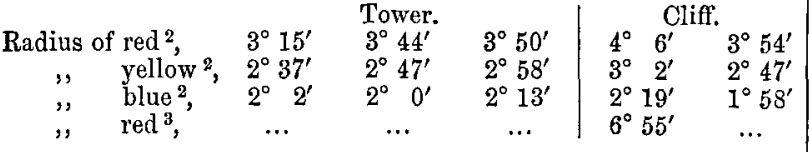

The fog occasionally rose above the level of the hill top, causing in each case a rapid and considerable fall of temperature.

Sept. 22.-The fog thinned away into haze in the forenoon, and a few hill tops showed above it at times.

Sept. 23.-Thick haze in the valleys all day, mixed with cum.-fog in the afternoon. Heavy dew on the top of thermometer box, and on black bulb at $20^{\mathrm{h}}$, but nowhere else. Aurora seen at night; misty confused arch-no streamers.

Sept. 25.-Though the wet bulb read a few tenths lower than dry for a few hours this morning, the air was obviously saturated.

Sept. 28.-At $3^{\mathrm{h}}$ aurora seen flashing in waves to northward; no well.defined arch and no streamers. At $6^{\text {h }}$ the "snow line" appeared to be between 2000 and 3000 feet. At $19^{\mathrm{b}}$ a lunar aurora was observed occasionally, formed on scud.

Sept. 29.-At $23^{\text {h }}$ cumulus clouds all round at about level of top of Ben Nevis.

Sept. 30.-Dense masses of cumulus over all hills round, and occasionally on Ben Nevis ; also during the day, but clearing at night. The earth shadow was seen after $18^{\text {h }}$ as the sun went down; it had been seen before sunrise on all clear days recently. A well-marked afterglow was seen at about $18^{\mathrm{h}} 50^{\mathrm{m}}$.

Oct. 1.-Thick haze and str.-fog in valleys and over hills in early morning. Earth shadow seen at $6^{\mathrm{h}}$. Cum.-fog formed all round in forenoon, and gradually rose till at about $14^{\mathrm{h}}$ it covered Ben Nevis.

Oct. 4.-The fog sank below the level of Ben Nevis in early morning, but continued to cover the other hills all day. When clearing a double lunar corona was observed. Measurements were got at $5^{\mathrm{h}}$, as noted in margin. Glories were also seen during the day on the fog to northward. The following measurements were $2^{\circ} 12^{\prime}$ - Orad got between $11^{\mathrm{h}}$ and $12^{\mathrm{h}}:-$ Five rings- $\quad \begin{aligned} & \text { Violet } \\ & \text { Blue }\end{aligned}$ radius of red ${ }^{5}$, too faint; $\mathrm{red}^{4}, 6^{\circ} 18^{\prime}$; red $^{3}$, Green $4^{\circ} 37^{\prime} ; \mathrm{red}^{2}, 2^{\circ} 40^{\prime} ; \mathrm{red}^{1}, 0^{\circ} 52^{\prime}$ (about). Yellow The earth shadow and the afterglow were Orange seen at $18^{\mathrm{h}}$. A lunar fog-bow was seen at $4^{\circ} 34^{\prime}-$ Red $23^{\mathrm{h}}$, radius to inner edge (about) $38^{\circ} 5^{\prime}$.

Oct. 5. - At $1^{\mathrm{h}}$ a few hill tops were showing through the fog. A lunar fog-bow was seen. At $2^{\mathrm{h}}$ the fog had risen higher, and was beginning to blow across the hill top. A distinct lunar fog-bow was seen, with traces of faint second bow outside it. The following measurements of the inner bow were got:-Radius inside of bow, $35^{\circ} 4^{\prime}$; outside of bow, $41^{\circ} 0^{\prime}$. A similar fog-bow was seen at $3^{\mathrm{h}}$; there appeared to be a faint trace of red about the outer edge of the inner bow. On both these occasions a faint white patch of light was seen round the shadow of the observer's head, which was probably a lunar glory. The fog-bow was seen again, but without any glory, at $4^{\mathrm{h}}$ and $5^{\mathrm{h}}$. The following measurements were made at $4^{\mathrm{h}}$ :Radius to inside of inner bow, $36^{\circ} 3^{\prime}$; outside, $41^{\circ} 0^{\prime}$.

Oct. 11 -At $2^{\mathrm{h}} 10^{\mathrm{m}}$ dry and wet were put out in small box on lowest stage of ladder-stand about 49 inches above ground. At and after $3^{\text {h }}$ the temperatures on the day's sheet are those of the small box.

Oct. 12.-The measurements of the amount of snow today are very doubtful, owing to drift.

Oct. 13. - The summit was enveloped in thin fog till $9^{\mathrm{h}}$;

TRANS. ROY. SOC. EDIN. VOL. XXXIV. 
was clear from $10^{\text {h }}$ till $13^{\text {h }}$ after which the fog came on again.

Oct. 14.-At $22^{\circ}$ and $23^{\circ}$ an aurora was observed. It had no streamers.

Oct. 15.-The fog cleared away at noon, but lay on surrounding hills, its upper surface being about on a level with the summit. On it, at $14^{\mathrm{h}}$, were observed a double fog-bow and glories, of which no measurements were obtained. A solar corona was seen at $14^{\mathrm{h}} 10^{\mathrm{m}}$, and again at $16^{\mathrm{h}} 10^{\mathrm{m}}$, triple each time. The following measurements were recorded :-

\begin{tabular}{|c|c|c|c|c|c|}
\hline \multicolumn{3}{|c|}{$14^{\mathrm{h}} 10^{\mathrm{m}}}$. & \multicolumn{3}{|c|}{$16^{\mathrm{h}} 10^{\mathrm{m}}}$. \\
\hline $\operatorname{Red}$ & $\operatorname{Red}^{2}$ & $\operatorname{Red}^{3}$ & Red 1 & $\operatorname{Red}^{2}$ & $\operatorname{Red}^{3}$ \\
\hline & $2^{\circ} 20 \frac{1}{2}^{\prime}$ & & $9^{\circ} 6^{\prime}$ & $3^{\circ} 35^{\prime}$ & \\
\hline
\end{tabular}

Oct. 16. - After $4^{\text {h }}$ the fog rose and enveloped summit, but cleared down again after $16^{\mathrm{h}}$, leaving a clear top for the rest of the day. The air was very dry after $20^{\mathrm{h}}$. Robinson's anemometer was set agoing at $14^{\mathrm{h}}$, and worked well for the rest of the day.

Oct. 17.- The cum.-fog that lay in valleys in early morning gradually rose, and as mist began to pass the summit at $7^{\mathrm{h}}$ completely enveloping it at $10^{\mathrm{h}}$. At $19^{\mathrm{h}}$ Robinson had to be tied up.

Oct. 18.-Robinson was let loose at $9^{\mathrm{h}}$.

Oct. 19.-Robinson was tied up at $20^{\mathrm{h}}$.

Oct. 21.-The fog cleared away at $10^{\mathrm{h}}$, and the summit remained clear till midnight. Till $14^{\mathrm{h}}$ the thermometer box and the thermometers had a coating of hard snow on them; after that hour they were cleared. A feeble aurora was clear at $22^{\mathrm{h}}$.

Oct. 23.- Mist and fog covered the summit all day except at $20^{\mathrm{h}}$ and midnight. At the latter hour a faint glimmering light, probably auroral, was seen to north wards. At $9^{\mathrm{m}}$ the anemometer (Robinson's) was tied up, having been working since $13^{\mathrm{h}}$ yesterday.

Oct. 26. - Glazed-frost or a coating of ice formed on all exposed surfaces all forenoon. At $22^{\mathrm{h}}$ the anemometer (Robinson's) was let loose.

Oct. 28. - A flash of lightning was seen at $1^{\mathrm{h}} 7^{\mathrm{m}}$, as the anemometer was being tied up. A very heavy shower of snow and snow-hail fell during a squall that began at $3^{\text {h }}$ $27^{\mathrm{m}}$ and ended at $3^{\mathrm{h}} 33^{\mathrm{m}}$. At $4^{\mathrm{h}}$ the rain-gauge recorded 0.335 inch.

Oct. 29. - At $1^{\mathrm{b}} 5^{\mathrm{m}}$ St Elmo's fire was seen in jets 3 to 4 inches long on every point on the top of the tower and on the top of the kitchen chimney. Owing to the number of jets on each cup of anemometer, this instrument was quite ablaze. On the kitchen chimney the jets on the top of the cowl were vertical, and those on the lower edge of same horizontal. The fizzing noise from the different places was very distinct. While standing on office roof watching the display, the observer felt an electric sensation at his temples, and the second assistant observed that his (the observer's) hair was glowing. While standing erect the sensation and glow lasted, but on bending down they always passed off. On raising the snow-axe a little above his head a jet 2 to 3 inches long shot uut at the top. At $1^{\mathrm{h}} 15^{\mathrm{m}}$ the fire vanished from every place at the same instant. A shower of snow and snow-hail (conical) was falling at the time, and the wind was a variable S. to S.W. breeze-very flawy. (The measurements of length of jets were only roughly estimated; the jets on kitchen chimney varied from 3 to 6 inches approxi- mately). At $19^{\mathrm{h}}$ St Elmo's fire was again seen. At $21^{\mathrm{h}}$ $25^{\mathrm{m}}$ the thermometer (ladder-stand) box was shifted, the hinge of the box door having fouled, and the louvres being choked with hard snow.

Oct. 31 . From $16^{\mathrm{h}}$ till $20^{\mathrm{h}}$ the summit was clear. At $20^{\mathrm{h}}$ a lunar corona was seen. At $23^{\mathrm{h}}$ the rain-gauge was covered with drifted snow, and could not be found.

Nov. 1.-The rain-gauge was found at $5^{\text {h }}$ and brought in, and was not put out again till $19^{\mathrm{h}}$.

Nov. 2.-In afternoon it was observed that the snow crystals forming from the fog were slightly brown.

Nov. 3.-The rain-gauge was not shifted at $4^{\mathrm{h}}, 5^{\mathrm{h}}$, and $6^{\mathrm{h}}$, owing to the heavy drifting at these hours.

Nov. 4.-At $1^{\text {th }}$ the summit cleared, leaving amount 5 of strato-cirrus on sky, which moved quickly from E.N.E., and retreated slowly towards N.W.; its southern limit was sharply defined. At $1^{\mathrm{h}} 20^{\mathrm{m}}$ the thermometer box was shifted. The road is now quite impracticable for horses.

Nov. 6.-At $1^{\mathrm{h}}, 3^{\mathrm{h}}$, and $4^{\mathrm{h}}$ a lunar halo was observed. At $4^{\mathrm{h}}$ there were apparently four distinct cloud-strata, viz., beginning with the lowest:-1st, cumulus-fog on hills; 2nd, cumulo-stratus and scud moving quickly from eastward; 3rd, cirro-cumulus moving from (S.E. ?) slowly; 4th, cirro-stratus pallium with halo moving from (S.S.E ?).

Nov. 7.-The barometer was pumping wildly almost all day. The measurements of amount of snow to-day are very doubtful, owing to drift.

Nov. 9.-A lunar corona was seen at $4^{\text {h }}$. The thermometer box was shifted after the $4^{\mathrm{h}}$ observation; its height above the snow was not altered. Thin fog was passing the summit occasionally in the forenoon, but during the afternoon the summit was clear and the sky cloudless. An aurora was seen at night, faintly at $8^{\text {h }}$ and $9^{\mathrm{h}}$, but with well-defined streamers at midnight.

Nov. 10.-Fog was observed on eastern hills at $1^{\text {h }}$, which gradually crept westwards till by $7^{\mathrm{h}}$ all the surrounding hills were covered. From $7^{\mathrm{h}}$ till $10^{\mathrm{h}}$ it brushed past the summit at times, but after $10^{\mathrm{h}}$ and for the rest of the day it enveloped the Ben, breaking, however, at times overhead, showing a clear blue sky above. As this fog came up to the Ben, the air temperature became very unsteady.

Nov. 11.-Fog on summit till $13^{\mathrm{h}}$, sinking thereafter to about 4000 feet, leaving Ben clear for the rest of the day. At $14^{\mathrm{h}}$ a glory was seen on fog in the corrie to northwards. A pink afterglow was observed from $16^{\mathrm{h}} 45^{\mathrm{m}}$ till $17^{\mathrm{h}}$.

Nov. 12. - Fog began to blow over summit at $9^{\text {h }}$, and settled thereon after $12^{\mathrm{h}}$. At $9^{\mathrm{h}}$ a glory was observed, and measurements of its red rings were obtained, viz. :-

$$
\begin{aligned}
& \operatorname{Red}{ }^{1} \text {. . . } \quad 2^{\circ} 46^{\prime} \quad 2^{\circ} 53^{\prime} \\
& \operatorname{Red}^{2}, \quad \cdot \quad \cdot \quad \cdot \quad 4^{\circ} 41 \frac{1}{2}^{\prime} \quad 4^{\circ} 31^{\prime} \\
& \operatorname{Red}^{3}, \quad . \quad . \quad . \quad \ldots \quad \ldots
\end{aligned}
$$

From $20^{\mathrm{h}}$ till $23^{\mathrm{h}}$ the summit was clear, but the sky was overcast with thin stratus.

Nov. 13.-To-day began with a clear top, but an overcast sky of thin stratus. Fog came on at $4^{\mathrm{h}}$ and lasted till $8^{\mathrm{h}}$, and was passing summit at times till $14^{\mathrm{h}}$. A fogbow was seen at $11^{\mathrm{h}} 20^{\mathrm{m}}$ and a glory at $15^{\mathrm{h}}$. The following measurements of red rings of glory were obtained, viz: :Red ${ }^{1}, 0^{\circ} 53^{\prime} ; \operatorname{red}^{2}, 1^{\circ} 50^{\prime}$; and red $^{3}, 3^{\circ} 46^{\prime}$. An aurora was sun at $20^{\mathrm{h}}, 22^{\mathrm{h}}$, and $23^{\mathrm{h}}$. At $22^{\mathrm{h}} 20^{\mathrm{m}}$ it broke up into 
streamers. The black bulb was out till $16^{\mathrm{h}}$, maximum registered, $99^{\circ} \cdot 0$. The thermometer-box was shifted at $10^{\mathrm{h}}$ $30^{\mathrm{m}}$.

Nov. 14.-At $2^{\mathrm{h}}$ and $3^{\mathrm{b}}$ three of the lights of the west coast lighthouses could be seen. The sky, cloudless at $1^{\text {h }}$ became overcast with stratus at $2^{\text {h }}$ (through which the stars were dimly visible till $6^{\mathrm{h}}$ ) and remained so till $15^{\mathrm{h}}$, after which it rapidly cleared and was cloudless at $19^{\mathrm{h}}$. Fog came on at $20^{\mathrm{h}}$ and enveloped summit till $23^{\mathrm{h}}$ but at midnight the summit was again clear and the sky cloudless, but fog covered the surrounding hills.

Nov. 15.-By $1^{\text {h }}$ the fog that lay on the surrounding hills had disappeared. At $1^{\mathrm{h}}$ and $2^{\mathrm{h}}$ the west coast lights were visible. The sky was cloudless or almost so till noon, after which it became overcast, and remained so till $17^{\mathrm{h}}$. At $18^{\mathrm{h}}$ it was again cloudless, but at $19^{\mathrm{h}}$ fog came on, and enveloped the summit for the rest of the day. Bright meteors with long trains were seen at the following times:-

$1^{\mathrm{h}} 8^{\mathrm{m}} 30^{\mathrm{s}}$, path from S.S.W., $30^{\circ}$ altitude to S.W. $15^{\circ}$ altitude.

$1^{\mathrm{h}} 15^{\mathrm{m}} 15^{\mathrm{s}}$, path from S.S.W., $40^{\circ}$ almost parallel with above.

$1^{\mathrm{h}} 17^{\mathrm{m}} 45^{\mathrm{s}}$, path from S.S.W., $20^{\circ}$ almost parallel with above.

$1^{\mathrm{h}} 19^{\mathrm{m}} 0^{\mathrm{s}}$, path from Mirach (Andromeda) to $\alpha$ Arietes.

$1^{\text {h }} 22^{\mathrm{m}} 0^{\mathrm{s}}$, path from Rigel towards S.S.W., almost parallel to horizon.

$1^{\mathrm{h}} 24^{\mathrm{m}} 0^{\mathrm{s}}$, path from Sirius towards S.S.W., almost parallel to horizon.

$1^{\mathrm{h}} 32^{\mathrm{m}} 30^{\mathrm{s}}$, path from a Arietes to western horizon.

$1^{\mathrm{h}} 33^{\mathrm{m}} 30^{\mathrm{s}}$, path from (?) towards western horizon.

$2^{\mathrm{h}} 5^{\mathrm{m}} 10^{\mathrm{s}}$, path from S. $15^{\circ}$ altitude to S.S.W., $5^{\circ}$ altitude.

$2^{\mathrm{b}} 11^{\mathrm{m}} 30^{\mathrm{s}}$, path from S.E. by E., $12^{\circ}$ altitude to S.S.E., $5^{\circ}$ altitude.

$2^{\mathrm{h}} 12^{\mathrm{m}} 0^{\mathrm{s}}$, path from S.E. by E., $12^{\circ}$ altitude to S.S.E., $5^{\circ}$ altitude.

$2^{\mathrm{h}} 17^{\mathrm{m}} 45^{\mathrm{s}}$, path from low to southward inclining to horizon to S.S.W.

Nov. 18. - The record of the direction anemometer today is very doubtful till $15^{\mathrm{h}}$, as the vane had been sheltered by the chimney and other instruments on the tower, which were all covered heavily with snow and ice. At $15^{\mathrm{h}}$ the vane was broadside to the wind. After that hour the snow was cleared away, and the vane worked all right for the rest of the day.

Nov. 20.-At $3^{\mathrm{h}}$ and $4^{\mathrm{h}}$ a pale light (probably auroral) was seen behind the clouds to northwards. At $4^{\mathrm{b}} 20^{\mathrm{m}}$ the thermometer box was shifted. At $8^{\mathrm{h}}$ a solar corona was seen. Radius of $\mathrm{red}^{1}, 4^{\circ} 10 \frac{1}{2}^{\prime}$, and of $\mathrm{red}^{2}, 6^{\circ} 48^{\prime}$. At the same hour a few hexagonal starry snow crystals were falling. A glory was seen at $10^{\mathrm{h}}$, having three well-defined colour-rings-red, green, and yellow. At $22^{\mathrm{h}}$ and $23^{\mathrm{h}}$ an aurora was seen. It had no streamers, had ill-defined boundaries, and was of uniform brightness.

Nov. 21.-At $18^{\mathrm{h}}$ and $19^{\mathrm{h}}$ an aurora was seen. No streamers were observed. At midnight dry and wet bulbs were 34 inches above snow.

Nov. 22.-Fog covered the hill top till $3^{\mathrm{h}}$, and passed occasionally till $15^{\mathrm{h}}$, but during the rest of the day the top was clear and the sky cloudless. At $21^{\mathrm{h}}$ and $23^{\mathrm{h}}$ an aurora was seen, at the former hour with streamers. The air was very dry at midnight, the humidity then being 19 .
At $22^{\mathrm{h}} 15^{\mathrm{m}}$ the thermometer box was shifted one step up on ladder-stand.

Nov. 23. - The sky was cloudless till 8 A.M., after which it became overcast or nearly so, and at $19^{\mathrm{h}}$ fog came on and enveloped hill top for the rest of the day. All morning and till $17^{\mathrm{h}}$ the air was very dry. At midnight the "fog"-crystals deposited seemed to be a mixture of icy crystals and snow (white) crystals. At $4^{\text {b }}$ there was a trace of an aurora in northern sky.

Nov. 24.-From $7^{\text {h }}$ till $13^{\mathrm{h}}$ " glazed frost" was forming on all exposed surfaces. Hard dry conical snow was falling at night. At $22^{\mathrm{h}}$ it was observed that the fog at times had a misty feel.

Nov. 25.-St Elmo's fire was seen faintly at $4^{\text {h }}$ for only about half a minute, and again at $4^{\mathrm{h}} 35^{\mathrm{m}}$ brightly, and for some minutes. At $1^{\mathrm{h}} 59^{\mathrm{m}}$ there was a "dot" signal in telegraph instrument (current down the line), and at $4^{\mathrm{b}} 9^{\mathrm{m}}$ a "dash" signal (current $u p$ the line). The wind was very variable to-day. Heavy rain began to fall after $23^{\mathrm{h}}$.

Nov. 27. - Top was clear at $16^{\mathrm{h}}$ and $17^{\mathrm{h}}$, and again after $22^{\mathrm{h}}$. At midnight a lunar halo was seen, having a trace of red inside at part nearest zenith only. Radius of inner edge per stephanome was $21^{\circ} 2^{\prime}$, and of the middle or brightest part $22^{\circ} 36^{\prime}, 22^{\circ} 24^{\prime}, 21^{\circ} 48^{\prime}$. At $20^{\text {l1 }}$ a hare's tracks were seen on the snow at the thermometer box.

Nov. 28. - The thermometer box was shifted at $0^{\mathrm{h}} 30^{\mathrm{m}}$. Fog came on at $4^{\mathrm{h}}$, and fine snow began to fall in needleshaped crystals. At $22^{\mathrm{b}}$ it was clear at times, and a corona was observed, and a halo was seen faintly through the fog. The following measurements of radii of colours in corona were obtained by stephanome, viz. :-

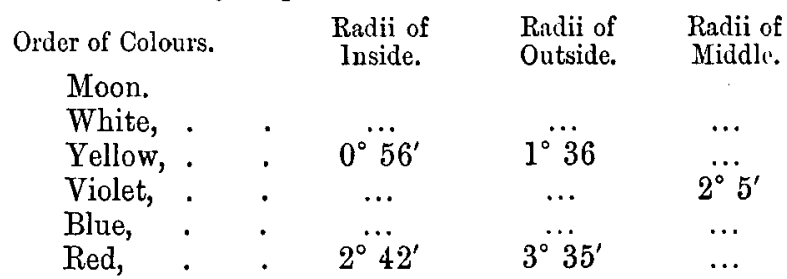

A hare's tracks were again seen to-day at $4^{\text {h }}$ on snow at rain-gauge.

Nov. 29.-The fog cleared off hill top at $8^{\text {h }}$, but lay in detached masses on lower hills and in valleys more or less all day. From $15^{\mathrm{h}} 10^{\mathrm{m}}$ to $15^{\mathrm{h}} 20^{\mathrm{m}}$ a solar corona was observed, and the following stephanomic measurements were obtained, viz.:-

White. Yellow-

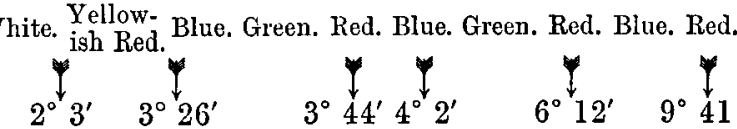

Triple lunar coronæ were seen at $18^{\mathrm{h}} 10^{\mathrm{m}}$ and again at $23^{\mathrm{h}} 15^{\mathrm{m}}$. The following measurements were obtained at $22^{\mathrm{h}} 15^{\mathrm{m}}$ per stephanome, viz.:-

DWhite. Yellowish Red ${ }^{1}$. Violet. Blue. Red ${ }^{2}$. Violet. Blue. Red ${ }^{3}$.

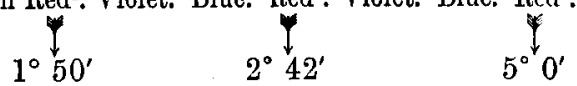

At times the white space about $D$ widened, making the corona a double one only $\operatorname{red}^{2}\left(2^{\circ} 42^{\prime}\right)$ being then the first coloured ring from the moon.

Nov. 30.-At $0^{\mathbf{h}} 5^{\mathrm{m}}$ a strato-cirrus cloud layer was seen to northward lying N.E. and S.W. and advancing 
from north-westward; its advancing edge was then rather less than $20^{\circ}$ above horizon. A few straggling pieces of cirrocum. were here and there on sky, also moving from northwestward. At $0^{\mathrm{m}} 10^{\mathrm{h}}$, and while the advancing edge of cloud stratum was still $41^{\circ} 39^{\prime}$ per stephanome, to westward or north-westward of moon, a halo began to form about halfway between moon and cloud. A spot in the halo brighter than the rest of it was apparently a faint mock moon. To this spot the radius was $23^{\circ} 58^{\prime}$ per stephanome. The following notes were taken of progress of cloud, \&c. :- $-0^{\mathrm{h}} 15^{\mathrm{m}}$, halo complete. Cloud just entering western side of halo. Radius per stephanome, $23^{\circ} 3^{\prime}$. $0^{\mathrm{h}} 19^{\mathrm{m}}$ edge of cloud at zenith and at moon; halo gone. No trace of corona on cloud. Moon shining pretty strongly through. $0^{\mathrm{h}} 35^{\mathrm{m}}$, halo faintly visible. White beams radiating from moon, some of them reaching halo. Cloud of uniform thickness; no appearance of anything to cause beams or breaks in moonlight. $0^{\mathrm{h}} 46^{\mathrm{m}}$, a uniform pallium of stratus-like cloud much lower than before $0^{\mathrm{h}} 35^{\mathrm{m}}$ with corona, which has white core, and yellowish red border; extreme outside measuring from moon, $2^{\circ} 13^{\prime}$. All appearances of halo gone. $0^{\mathrm{h}} 50^{\mathrm{m}}$, shadow of eastern edge of cloud now at west end of Loch Laggan (unbroken moonlight to eastward of that), and cloud touching (apparently) the hills at Corran and Glencoe. $0^{\mathrm{h}} 55^{\mathrm{m}}$, lower surface of cloud just at Ben (no view to westward now) and beginning to brush top. Moon still visible, with corona as observed already; cloud still of uniform texture. Fog on at $1^{\text {h }}$. Temperature rising rapidly all forenoon; and at $10^{\mathrm{h}}$ the fog changed to mist, and glazed frost was forming till at $2 \mathrm{l}^{\mathrm{h}}$ the temperature had risen above $32^{\circ}$. Heavy rain falling at night.

Dec. 3.-Robinson was let loose at $22^{\mathrm{h}}$ last night, but was tied up at $4^{\text {h }}$ to-day, as it was observed that one cuparm was broken at shoulder, and was only held on by the metal stay from top of instrument. Cause of breakage unknown.

Dec. 5.-At $3^{\text {h }}$ it was difficult to tell whether the cloud enveloping summit was mist or fog, so "mist or fog" has been entered at that hour on daily sheet. The vane was frozen inside its supporting pillar all day.

Dec. 6. - The outside part of the $3^{\text {h }}$ observation was 3 minutes late, owing to lamp having been blown out. The measurements of snow to-day are very doubtful, owing to drift.

Dec. 7.-St Elmo's fire was seen at $1^{\mathrm{h}}$ on all points on tower and on observer's bat and pencil, but not on kitchen chimney; snow and snow-hail (conical) were falling heavily at the time.

Dec. 8.-Top and sky cleared a little in forenoon. At $7^{\mathrm{h}}$ a corona was seen on passing fog. At $16^{\mathrm{h}}$ the raingauge was buried in a snow wreath; it was taken in, and was not put out again till $20^{\mathrm{h}}$, owing to the heavy drift. At $22^{\mathrm{h}} 30^{\mathrm{m}}$ the thermometer box was shifted, and the fresh one was put one step higher on the ladder-stand than the other had been.

Dec. 9.-Top was clear at $4^{\mathrm{h}}$ and $5^{\mathrm{h}}$, and again mostly all afternoon. At $15^{\mathrm{h}}, 16^{\mathrm{h}}$, and $17^{\mathrm{h}}$, when the observed wind direction was N.N.E., the stratus or cumulus clouds immediately overhead were moving from N.N.W.

Dec. 10.-At $22^{\mathrm{h}} 5^{\mathrm{m}}$ a large red pear-shaped meteor was seen to northward about $5^{\circ}$ above level of Ben top moving westwards slowly. It was seen through thin fog.
Dec, 11.-At about $3^{\mathrm{h}} 5^{\mathrm{m}}$ a very bright meteor was seen. It started from about zenith, and vanished at $W$. end of Orion's belt. It increased rapidly, and just before bursting or vanishing was at its brightest; showing blue and green colour circles. It was seen for about $1 \frac{1}{2}$ secs. It brighted up the Ben top and bills to southward; no noise heard. After $10^{\text {h }}$ the thermometer box was shifted.

Dec, 12.-Storm all afternoon. After $20^{\mathrm{h}}$ there was no gauge out, but apparently no snow fell.

Dec. 13. - Storm continued all morning. At $9^{\text {h }}$ it was found that ozone test had been blown away. At $2^{\mathrm{h}} 50^{\mathrm{m}}$ vane began to spin round at a great rate, owing to having been partially sheltered by the snow on chimney and the other instruments on tower. The rain-gauge was not put out till $7^{\mathrm{h}}$, but apparently no snow fell till then.

Dec. 14.-The snow was drifting very much in early morning, consequently the amounts on sheet are rather doubtful. Somewhat stormy in afternoon.

Dec. 15.-Shifted thermometer box at $1^{\mathrm{h}} 30^{\mathrm{m}}$. Sky was cloudless till $6^{\mathrm{h}}$, fog after that till $11^{\mathrm{h}}$, cloudy sky till $14^{\mathrm{h}}$, and fog for the rest of the day. At $14^{\mathrm{h}}$ low stratusfog on south-western and western hills clinging to hills; shortly after $14^{\mathrm{h}}$ this fog developed into cum.-fog, and came rapidly eastward enveloping Ben at $14^{\mathrm{h}} 35^{\mathrm{m}}$. The upper sky was overcast with cirro-cum., and midway between upper and lower strata a few dark long detached cum.-str. clouds were observed. The air temperature as the fog began to pass Ben was $23^{\circ} 0^{\prime}$.

Dec. 16.-St Elmo's fire was seen at $20^{\mathrm{h}}$ and $22^{\mathrm{b}}$, at the latter hour on observer only. At $22^{\mathrm{h}}$ and $23^{\mathrm{h}}$ there was a misty feel in the air at times, and an icy cake was observed on rain-gauge, thermometer box, and other exposed surfaces.

Dec. 17.-Wind very variable and squally all forenoon, and snow drifting a good deal, rendering the measurements of amount obtained rather doubtful. The top was clear for about an hour at mid-day, but sky was cloudy with str. and cum.-str.

Dec. 18.-The fog cleared away after $11^{\mathrm{h}}$, and the summit was clear till $19^{\mathrm{h}}$, after which fog came on again. In afternoon the western and south-western horizon was rather wild-looking with cir. and cum.-str. clouds, and there was low str.-fog clinging to hills. After the $12^{\mathrm{h}}$ observation the thermometer box was shifted; the fresh one was put one step higher (the last step) on ladder-stand than the other had been. A pink afterglow and the earth shadow were seen at $16^{\text {h }}$, both well defined.

Dec. 20.-The wind was very squally and variable today, and the barometer was pumping heavily mostly all day. Hard icy drift blown from the cliff, and falling in gange made the measurements of snow amount worthless; but as it was believed that snow was falling in early morning, 060 inch has been allowed in total fall for day.

Dec. 21.-Top was clear after $11^{\mathrm{h}}$, but fog was hanging around Ben and thin stratus covered sky. In afternoon it was observed that the country was snow-clad to sealevel. At each observation after $20^{\mathrm{h}}$ an aurora was seen to northward; at $22^{\mathrm{h}}$ only a small part of it could be seen between clouds and horizon, but this part was very bright, flashing with red, yellow, and blue colours, the flashes moving from $\mathrm{E}$. to $\mathrm{W}$. After $20^{\mathrm{h}}$, the thermometer box was shifted. A lunar corona was seen at $21^{\mathrm{h}}$ and $22^{\mathrm{h}}$, but no measurements were obtained; at $22^{\mathrm{h}}$ the order of 
colours were-D, green, yellow, red. Sky was cloudless at midnight.

Dec. 22.-Aurora seen at $1^{\mathrm{h}}$, with bright horizontal streaks. Top of aurora was about $10^{\circ}$ altitude, and was not well defined, but thinned off into the general tint of the sky; at the same time the horizon to northward and northwestwards was very dark. The top continued clear and the sky cloudless till $3^{\mathrm{h}}$. At $2^{\mathrm{h}}$ the south-western lights were visible, and at same hour stratus streaks were seen low to N.W., lying N.E. and S.W. Fog came on at $4^{\mathrm{h}}$, changed to mist at $15^{\mathrm{h}}$, and cleared away at $22^{\mathrm{h}}$. Glazed frost was forming in afternoon. A lunar corona was seen at $23^{\mathrm{h}}$. At midnight fog covered the hills around to 4000 feet, leaving Ben alone clear; at same hour sky was cloudless. All afternoon the thermometer box was rather badly choked with ice.

Dec. 23. - The thermometer box was shifted at $0^{\mathrm{h}} 25^{\mathrm{m}}$. The summit was clear till $11^{\mathrm{h}}$. The air was very dry in early morning, the humidity at $4^{\text {h }}$ being only 10 per cent. Glazed frost formed heavily and rapidly from a very wet mist which prevailed all afternoon. The thermometer box got so heavily encrusted that at $17^{\mathrm{h}}$ there was difficulty in opening it, and the readings of the dry and wet were $7^{\mathrm{m}}$ late in consequence.

Dec. 24. - The top cleared at $15^{\mathrm{h}}$, and from then till $23^{\mathrm{h}}$ the sky (except for a little cir. at $22^{\mathrm{h}}$ ) was cloudless. At $19^{\mathrm{h}}, 20^{\mathrm{h}}$, and $21^{\mathrm{h}}$ there was neither fog below nor cloud above, but at $22^{\text {h }}$ there was fog all round, except to southward, on hills to about the level of summit, occasionally passing summit, and causing coronæ, of which the following measurements per stephanome were obtained:-

$$
\begin{array}{lccc} 
& \operatorname{Red}^{1} & \operatorname{Red}^{2} . & \operatorname{Red}^{3} . \\
\text { 1st set, } & 1^{\circ} 20^{\prime} 30^{\prime \prime} & 2^{\circ} 47^{\prime} 0^{\prime \prime} & 4^{\circ} 25^{\prime} 0^{\prime \prime} \\
\text { 2nd set, } & 1^{\circ} 27^{\prime} 0^{\prime \prime} & 2^{\circ} 37^{\prime} 0^{\prime \prime} & 4^{\circ} 0^{\prime} 30^{\prime \prime}
\end{array}
$$

Triple coronæ were also seen at $23^{\mathrm{h}}$, but were too fleeting to measure. At $16^{\text {h }}$ the earth shadow was seen, sharply defined, topped by a belt of rosy colour rising to eastward to about $20^{\circ}$ alt. At same hour the sunset colours to westward were red, at horizon sickly green to about $20^{\circ}$ alt., and pink afterglow above this to $45^{\circ}$ alt. The thermometer box was shifted at $15^{\mathrm{h}}$. Fog-bows were seen at $22^{\mathrm{h}}$ and midnight.

Dec. 25.-The top was clear from $18^{\mathrm{h}}$ to $21^{\mathrm{h}}$, but fog lay in detached masses on hills around. The sky was cloudless at $18^{\mathrm{h}}$ and $19^{\mathrm{h}}$, but cloudy afterwards, and coronze were seen at $20^{\mathrm{h}}$ and $21^{\mathrm{h}}$. Needle-shaped snow crystals were falling at $22^{\mathrm{h}}$ and $23^{\mathrm{h}}$.

Dec. 26. - The fog cleared away after $6^{\mathrm{h}}$, and till $15^{\mathrm{h}}$ the sky was cloudless, but there was a good deal of stratus-fog on the other bills all round. The top was covered in fog again from $16^{\mathrm{h}}$ till $22^{\mathrm{h}}$, and at $23^{\mathrm{h}}$ and midnight fog was passing at times. After $11^{\mathrm{h}}$ the thermometer box was shifted. At $23^{\mathrm{h}}$ and midnight coronæ were observed (double); at former hour following measurements were obtained :- Inner red, $5^{\circ} 3^{\prime}$; and outer red, $9^{\circ} 28^{\prime}$.

Dec. 27.-A double corona was first seen at $1^{\text {h }}$ and the following measurements per stephanome were obtained, viz. :-

$$
\begin{array}{lll}
\text { 1st set, } & 4^{\circ} 34^{\prime} & 8^{\circ} 4^{\prime} \\
\text { 2nd set, } & 4^{\circ} 46^{\prime} & 8^{\circ} 22^{\prime}
\end{array}
$$

The summit was clear till $19^{\mathrm{b}}$, but fog on after that. The thermometer box was shifted after $10^{\mathrm{h}}$. At $22^{\mathrm{h}}$ a

TRANS. ROY. SOC. EDIN. VOL. XXXIV. corona was observed, with white and red as only colours measurements of outside of red gave $2^{\circ} 6^{\prime}$ as radius.

Dec. 28.-Double and triple coronæe were seen at $3^{\text {h }}, 4^{\text {h }}$, and $5^{\mathrm{h}}$, and fog-bows at $4^{\mathrm{h}}$ and $5^{\mathrm{h}}$. At $3^{\mathrm{h}}$ the extreme outer edge of the first red (i.e., red nearest moon) was measured, with following result:-Radius on 1st red, $3^{\circ} 31^{\prime}$; $2^{\circ} 6^{\prime} ; 2^{\circ} 6^{\prime} ; 3^{\circ} 42^{\prime}$. At times the $2^{\circ} 6^{\prime}$ red was the inner red in a double corona, in which the $3^{\circ} 42^{\prime}$ red was the outer. Fog was on summit, or passing till $18^{\mathrm{h}}$, after which it sank, and gradually diminished in quantity till at $23^{\mathrm{h}}$ and midnight there were only detached str.-fog pieces low to north and north-eastward.

Dec. 29.- At $1^{\mathrm{h}}$ there was a little str.-fog to northward and eastward, but by $5^{\mathrm{h}}$ there was fog all round, with very few breaks. After $7^{\text {h }}$ it began to rise as a whole, at $8^{\text {h }}$ it was passing eastern end of summit, and at $9^{\mathrm{h}}$ it was passing generally, and the air (till then dry) was saturated. At $10^{\mathrm{h}}$ the fog began to break up, the south-western hills clearing first; but after $14^{\mathrm{h}}$ it began to close all round again, and from $18^{\text {h }}$ till midnight it was either on or passing the summit. At $7^{\mathrm{h}}$ and $8^{\mathrm{h}}$ cir. and cir.-str. clouds were seen at north-eastern horizon. From $13^{\mathrm{h}}$ to $16^{\mathrm{h}}$ the sky was almost covered with cirrus; but at $18^{\mathrm{h}}$ and till midnight the upper sky was cloudless. The following measurements of the radii of red rings in lunar coronæ were obtained at night :-

20 honrs, $\begin{array}{ccccc}1 \text { st Red. } & \text { 2nd Red. } & \text { 3rd Red. } & \begin{array}{c}\text { No. of Red } \\ \text { Rings seen. }\end{array} \\ 1^{\circ} 42^{\prime} & 3^{\circ} 28^{\prime} & 5^{\circ} 52^{\prime} & 3 & \\ 1^{\circ} 55^{\prime} & 4^{\circ} 20^{\prime} & \ldots & 2 & \text { 1st set. } \\ 1^{\circ} 54^{\prime} & 3^{\circ} 25^{\prime} & \ldots & 3 & \text { 2nd ,", } \\ 1^{\circ} 44^{\prime} & 3^{\circ} 15^{\prime} & 5^{\circ} 0^{\prime} & 3 & \text { 3rd ", } \\ 2^{\circ} 24^{\prime} & 4^{\circ} 13^{\prime} & \ldots & 2 & \text { Ist ," } \\ 2^{\circ} 24^{\prime} & 3^{\circ} 46^{\prime} & \ldots & 2 & \text { 2nd ,", } \\ 1^{\circ} 54^{\prime} & 2^{\circ} 59^{\prime} & 5^{\circ} 0^{\prime} & 3 & \text { 3rd ," }\end{array}$

(measurements made in each case to extreme outside of red). When the corona was triple all the colours of spectrum were seen between red ${ }^{1}$ and red $^{2}$, the blue usually brightest. The broken cup-arm of the Robinson anomometer was spliced after $14^{\mathrm{h}}$ to-day.

Dec. 30.-Thin fog on summit till $4^{\mathrm{h}}$, after which it sank, remaining on hills for the rest of the day with its upper surface from 3000 to 4000 feet above sea-level. In the early morning the following measurements of radii of red rings in lunar coronæ were obtained per stephanome;

\begin{tabular}{|c|c|c|c|c|c|}
\hline (1st se & $\begin{array}{l}\text { 1st Red. } \\
1^{\circ} 43^{\prime}\end{array}$ & $\begin{array}{l}\text { 2nd Red. } \\
3^{\circ} 13 \frac{1^{\prime}}{2}\end{array}$ & $\begin{array}{l}\text { 3rd Red. } \\
4^{\circ} 43^{\prime}\end{array}$ & $\begin{array}{r}\text { 4th Red. } \\
6^{\circ} 48^{\prime}\end{array}$ & $\begin{array}{l}\text { No. of Red } \\
\text { Rings seen. } \\
4\end{array}$ \\
\hline $\begin{array}{l}\text { 2nd, , } \\
\text { 3rd }\end{array}$ & 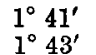 & $\begin{array}{ll}3^{\circ} & 9^{\prime} \\
2^{\circ} & 56^{\prime}\end{array}$ & $5^{\circ} 0^{\prime}$ & $\cdots$ & $\begin{array}{l}3 \\
3\end{array}$ \\
\hline 4th" & $1^{\circ} 44^{\prime}$ & $2^{\circ} 52^{\prime}$ & & $\cdots$ & 3 \\
\hline 5th ," & $1^{\circ} 43^{\prime}$ & $3^{\circ} 10 \frac{1}{2}^{\prime}$ & $4^{\circ} 56^{\prime}$ & $\ldots$ & 3 \\
\hline (6th ," & $\begin{array}{l}1^{\circ} 43^{\prime} \\
1^{\circ} 33^{\prime}\end{array}$ & $\begin{array}{c}3^{\circ} \quad 4^{\gamma} \\
2^{\circ} 47^{\prime}\end{array}$ & $4^{\circ} 43^{\prime}$ & $\ldots$ & $\begin{array}{l}3 \\
3\end{array}$ \\
\hline 2nd,", & $1^{\circ} 22^{\prime}$ & $2^{\circ} 30^{\prime}$ & $\cdots$ & $\cdots$ & 3 \\
\hline 3rd", & $1^{\circ} 49 y^{\prime}$ & $2^{\circ} 33^{\prime}$ & $3^{\circ} 56^{\prime}$ & $\ldots$ & 4 \\
\hline 4 th, & $1^{\circ} 21^{\prime \prime}$ & $2^{\circ} 33^{\prime}$ & $3^{\circ} 46^{\prime}$ & $\ldots$ & 3 \\
\hline $\begin{array}{l}5 \text { th }, \\
6 \text { th ", }\end{array}$ & $\begin{array}{l}1^{\circ} 27 \frac{1}{3}^{\prime} \\
1^{\circ} 21 \frac{1^{\prime}}{2}\end{array}$ & $\begin{array}{l}2^{\circ} 39^{\prime} \\
2^{\circ} 27^{\prime}\end{array}$ & $\begin{array}{l}3^{\circ} 58^{\prime} \\
3^{\circ} 38^{\prime}\end{array}$ & $\begin{array}{l}\ldots \\
\cdots\end{array}$ & $\begin{array}{l}3 \\
3\end{array}$ \\
\hline (1st set, & $1^{\circ} 5^{\prime}$ & $2^{\circ} 6^{\prime}$ & $\cdots$ & $\ldots$ & 3 \\
\hline $\begin{array}{l}\text { 2nd ," } \\
\text { 3rd }\end{array}$ & $\begin{array}{ll}1^{\circ} & 4^{\prime} \\
1^{\circ} & 10^{\prime}\end{array}$ & $\begin{array}{cc}2^{\circ} & 4^{\prime} \\
2^{\circ} & 5^{\prime}\end{array}$ & $3^{\circ{ }^{\circ}} 13 \frac{1}{2}^{\prime}$ & $\cdots$ & $\begin{array}{l}3 \\
4\end{array}$ \\
\hline 4 th ", & $1^{\circ} 14^{\prime}$ & $2^{\circ} 17 \frac{1}{2}^{\prime}$ & $3^{\circ} 12^{\prime}$ & $4^{\circ} 37^{\prime}$ & 4 \\
\hline (5th ", & $\begin{array}{cc}6^{\prime} \\
1^{\circ} 36^{\prime}\end{array}$ & $\begin{array}{l}2^{\circ} 11^{\prime} \\
2^{\circ} 43^{\prime}\end{array}$ & $\begin{array}{ll}3 & 4^{\prime} \\
4^{\circ} & 5 t^{\prime}\end{array}$ & $\cdots$ & $\begin{array}{l}3 \\
4\end{array}$ \\
\hline 2nd," & $0^{\circ} 55 z^{\prime}$ & $1^{\circ} 51^{\prime}$ & & ... & 2 \\
\hline $3 \mathrm{rc}$ & $0^{\circ} 56 \frac{1^{\prime}}{2}$ & $1^{\circ} 35^{\prime}$ & $2^{\circ} 41^{\prime}$ & $\ldots$ & 4 \\
\hline & $56^{\prime}$ & $1^{\circ} 42^{\prime}$ & $2^{\circ} 51^{\prime}$ & $\ldots$ & 3 \\
\hline
\end{tabular}
the measurements were made to outside of red in each case, viz. :- 
At $4^{\mathrm{h}}$ fog-bow, radius inside, $37^{\circ} 10^{\prime}$; outside, $40^{\circ} 20^{\prime}$. The upper joint was put on ladder-stand at $15^{\mathrm{h}} 15^{\mathrm{m}}$. The earth shadow was seen at $8^{\mathrm{h}} 35^{\mathrm{m}}$ and again at $16^{\mathrm{h}}$. A glory was seen as $10^{\mathrm{h}}$. At $16^{\mathrm{h}} 30^{\mathrm{m}}$ gaps (streamer-like) were observed in the pink afterglow that filled the western sky, small bits of cir.-str. were seen very near the western horizon at same time.

Dec. 31.-The summit was clear and sky cloudless till $2^{\mathrm{h}}$. At $3^{\mathrm{h}}$ thin fog was passing, and at $4^{\mathrm{h}}$ and for the rest of the day the summit was enveloped. During the forenoon there was a "misty feel" in the fog, and at $15^{\mathrm{h}}, 16^{\mathrm{h}}$, and $17^{\mathrm{h}}$ it was distinctly mist that enveloped the top, yet the temperature of the air was about $22^{\circ}$. At $3^{\mathrm{h}}, 4^{\mathrm{h}}$, and $5^{\text {h }}$ corona were seen, and a fog-bow was noted at $7^{\mathrm{b}}$. At $3^{\mathrm{h}}$ the following measurements of coronæ were obtained :-

$\begin{array}{clll} & 1 \text { st set. } & \text { 2nd set. } & \text { 3rd set. } \\ \text { Radius of first red, } & 1^{\circ} 41^{\prime} & 1^{\circ} 21^{\prime} & 0^{\circ} 59 \frac{1}{2}^{\prime} \\ " \quad \text { of second red, } & 2^{\circ} 2^{\prime} & \ldots & \ldots \\ " \quad \text { of third red, } & 2^{\circ} 50^{\prime} & \ldots & \ldots\end{array}$

(measured to outside of red in each case.)

\section{INSTRUMENTS IN USE DURING 1887.}

Barometers.-No. 1385 was in use during the whole of 1887. No. 1252, though not in use, was hanging in position ready for use at any time. The Barograph worked most of the year; the note anent its scale error on page 343 above is still applicable.

Thermometers.-As Dry and Wet, Nos. 192660, 192672, 192671, 192677, 50850, and 50852 were used (for makers see pages 334 and 343 above).

As Self-Registering.-Max. No. 117293, and Mins. $116918,138545,138533$ were in use, the Max. and first Min. in "old clock box," and the other two in ladder-stand boxes.

Rain-Gauges.-Mr Omond's patterns of 5-inch Gauges were used, the deep-rimmed or the shallow-rimmed as the season and kind of precipitation required.

Anemometers.-For direction, Chrystal's Anemometer continued in use, and worked fairly well.
For Velocity.-After August 3 Robinson's Cup Anemometer was used when the weather permitted, i.e., when it was not freezing. Till August 3 it was out of gear. When regeared (August 3) an arrangement of bevel pinions was put instead of upper flexible part of shaft that communicates revolutions to counter. About the beginning of December one of its arms was broken, but it was put in working order again before the end of that month.

Sunshine Recorder.-The repaired Sunshine Recorder (see p. 343) was used, and worked well.

Mr Omond's pattern of Chrystal's Hygrometer was used several times during the year, and worked satisfactorily; but it was broken in September, and since then it has been out of repair.

From June 4 till Oct. 11 the Thermometers in use were placed in the old clock box; for the rest of the year in small boxes on ladder-stand.

The depth of Snow was always measured at post A.

The measurements of Rainfall were several times interrupted, and of ten rendered unsatisfactory, by drifting ; and the Ozone Tests were occasionally blown away and occasionally bleached.

With the above exceptions, the record for the year is continuous; though once or twice the observation, or part of it, was a few minutes late.

The Seismometer is still unsatisfactorily mounted (see p. 343). No results have been obtained from it during the year.

The Thermograph and Hair Hygrometer were not in use.

The Black Bulb in vacuo used was No. 186.

The Cosmic Dust Collector was out several times during the year.

For observing the rainband Hilger's pocket Spectroscope was used.

The permament staff of the Obvervatory consists of R. T. Omond, A. Rankin, J. Miller, and since Oct. 7, A. Drysdale.

From Aug. 3 till Sept. 21, Mr C. E. Gray acted as telegraph clerk at the Observatory.

Messrs William Hay, A. J. Herbertson, and J. Duncan took the places of some of the staff at various times.

\section{ERRATA.}

Page 13. Mean $12^{\mathrm{h}}$, instead of 5.083 , read 5.038 .

"43. Mean Midnight, instead of 5.692 , read $5 \cdot 685$.

"202. Amount 17 th, instead of 0.039 , read 0.038 . 